\title{
ORGANIC PLANT PRODUCTS ARE OF MORE IMPROVED CHEMICAL COMPOSITION THAN CONVENTIONAL ONES
}

\author{
Jelena M. Golijan*1, Mile D. Sečanski ${ }^{2}$ \\ ${ }^{1}$ University of Belgrade, Faculty of Agriculture, 11080 Belgrade, Nemanjina 6, Serbia \\ ${ }^{2}$ Maize Research Institute, 11185 Belgrade, Slobodana Bajića 1, Serbia
}

\begin{abstract}
Considering the negative effects of conventional agricultural production, organic food production is a sustainable approach to production, which preserves the environment and protects human health. Organic products are products of high quality, without residues of pesticides and other harmful chemicals. Through the review of literature data, the authors of this paper presented a comparative study on the chemical compositions of organically vs. conventionally grown plants and their products. Dry matter, nitrates, sugars, vitamins, macro-and microelements, as well as, secondary metabolites have been singled out. The analysis of collected data revealed that organic products contained more dry matter, significantly fewer nitrates, fewer proteins and a higher proportion of amino acids, more sugars, vitamin $\mathrm{C}$, numerous macro-and microelements (particularly Fe, Mg and P), more polyphenols and they had higher total antioxidant capacity than conventional products. Although many authors have been dealing for many years with the comparison of the nutritional composition of organic and conventional food products, a clear consensus whether organic products have an improved chemical composition compared to conventional products has not been reached yet, i.e. the conclusions are ambivalent. Therefore, further long-term studies are necessary to clarify the existing doubts.
\end{abstract}

Key words: organic production, conventional production, vitamins, minerals, secondary metabolites, nitrites

\section{INTRODUCTION}

Organic agricultural production can be most easily defined through its goals: the production of healthy and high-quality food through the preservation of the environment, soil and its fertility, biodiversity, agro- and ecosystem, with the simultaneous improvement of health and productivity of interdependent communities, life of land, plants, animals and people
(Mirecki, Wehinger \& Jaklič, 2011; Popović et al., 2016). The areas under organic plant production on a global level have been increasing, as well as, the organic products market (Popović, Golijan, Sečanski \& Čamdžija, 2017; Golijan \& Dimitrijević, 2018). According to the Research Institute of Organic Agriculture (FiBL, 2020): „Organic agriculture is prac- 
tised in 186 countries, and 71.5 million hectares of agricultural land are managed organically by approximately 2.8 million farmers. The global sales of organic food and drink reached more than 96 million euros in 2018". Numerous abiotic and biotic factors affect food quality. Many pollutants with very harmful effects on human health entered into the food production chain (soil-plant-animalhuman organism) from the environment as an abiotic factor (Figure 1). Some of these pollutants are heavy elements, pesticide residues, nitrogen compounds, mycotoxins, chlorinated biphenyls, aromatic hydrocarbons (e.g. benzo[a]pyrene), plant growth stimulators (e.g. choline chloride), antibiotics, hormones, radioactive isotopes and plastic substances (monomers) (Rembiałkowska, 2007). Today, agriculture is considered as one of the sources of increased greenhouse gas emissions, as well as a great polluter of the environment. Modern scientific knowledge integrated into sustainable production has reaffirmed those me- thods and technologies of the food production processes that favour the healing of disturbed ecosystems. Organic agriculture can be considered as one of the directions of this type of sustainable, safe and environmentally friendly production (Šeremešić et al., 2017).

Consumers in most countries have a positive attitude towards organically produced food. Considering that the system of organic production is fully legally regulated and the mandatory certification by competent certification institutions is required, consumers recognise organic products as safer and sounder to consume (Codron, Siriex \& Reardon, 2006). In this regard, the most common motif for consuming organic products is taking care of their own health, because consumers believe that organic products are healthier and with a higher content of nutrients compared to conventionally produced foods (Marques Vieira, Dutra De Barcellos, Hoppe \& Bitencourt da Silva, 2013; Golijan \& Veličković, 2015).

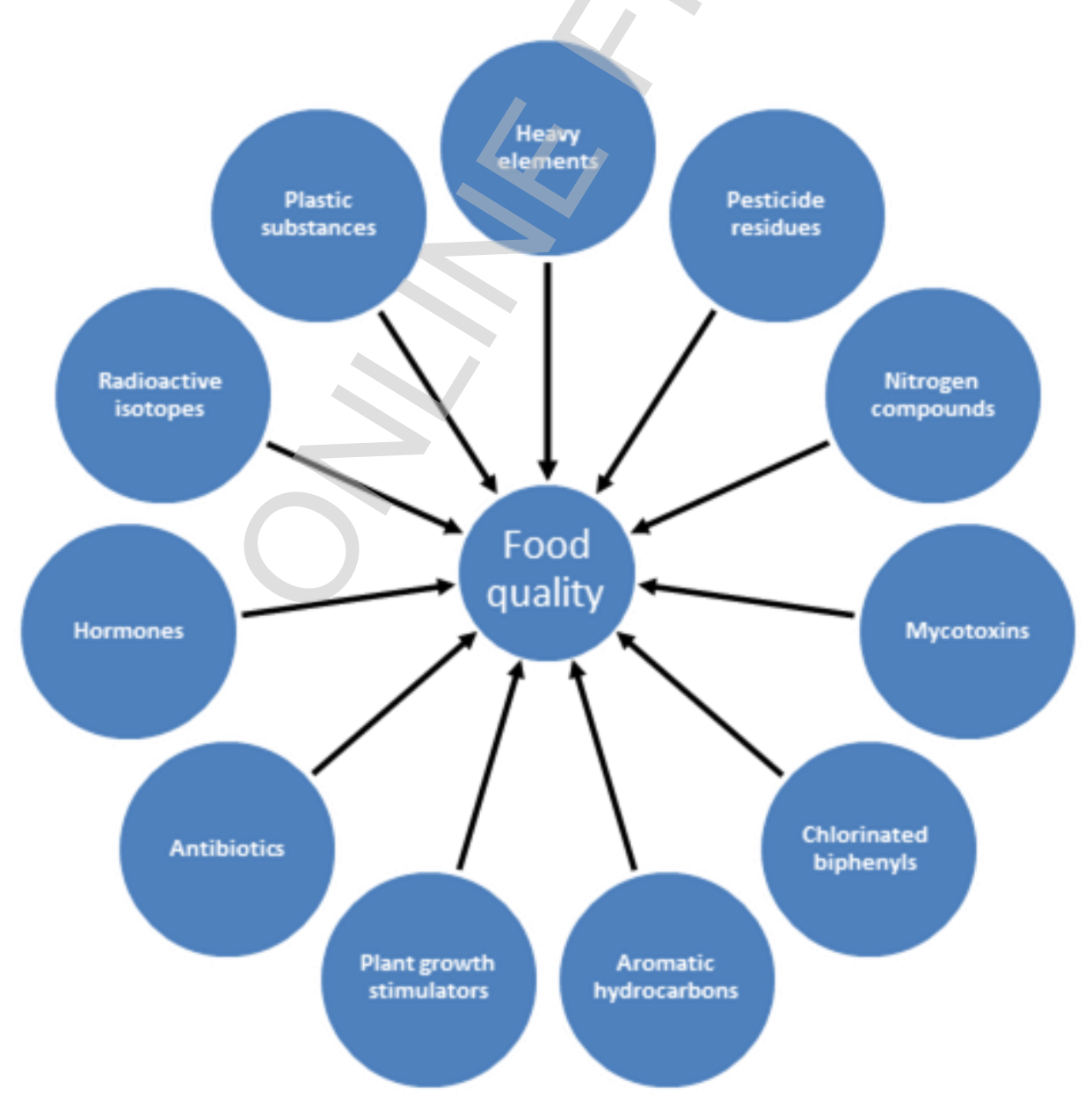

Figure 1. Pollutants that affect food quality 
Since the use of synthetic pesticides, i.e. fungicides in the control of pathogenic microorganisms is not allowed in organic production, the question of whether mycotoxins are more present in organic food production than in conventional ones has been the objecttive of studies performed by many researchers. Obtained results varied a lot. For instance, Lairon (2010) has stated that it was evident that food contamination with mycotoxins was widespread, but still at a low level, due to which was impossible to draw a general conclusion whether organic and conventional food production differed in terms of the level of mycotoxin contamination. Preventive protecttion measures in the organic mode of production, despite the exclusion of classical fungicides, provide the maintenance of a low level of infection, when present mycotoxins do not exceed the maximum tolerable concentrations. According to Golijan, Lekić, Vuković \& Sečanski (2020), who observed the content of mycotoxins in organically and conventionally produced seed of maize, spelt wheat and soya bean, there was only one sample of organic maize contaminated with aflatoxin B1 (1.16 $\mu \mathrm{g} / \mathrm{kg})$ and deoxynivalenol $(101.53 \mu \mathrm{g} / \mathrm{kg})$, in concentrations bellow maximum tolerable values given in the Regulation on the maximum allowed quantities of residues of plant protection products in food and feed.

Numerous researchers throughout the world have been for many years engaged in comparative studies of differences in the chemical composition between organically and conventionally grown plants and their products. Some of them presented review papers based on a large number of experiments. Some authors applied the meta-analysis to at least several hundred studies and drew conclusions about the effects of organic and conventional production methods on the chemical compositions of plants (Woëse, Lange, Boess \& Bogl, 1997; Worthington, 1998; Bourn \& Prescott, 2002; Heaton, 2001; Worthington, 2001; Rembiałkowska, 2007; Baranski et al., 2014, and many others). According to them, organic food products contain significantly more amounts of dry matter, total sugars, essential amino acids, vitamin $\mathrm{C}$, macro-and microelements (especially $\mathrm{Ca}, \mathrm{Mg}, \mathrm{Fe}, \mathrm{P}, \mathrm{Zn}$ ), phenolic compounds and significantly fewer nitrates than conventional food products (Figure 2).

The majority of data refers to vegetables and fruits and much less to cereals. Previous scientific data indicate that there is an insufficient number of studies related to the observation of the vitamin levels, particularly of $\beta$-carotene and vitamin B complex (Golijan \& Veličković, 2015). Moreover, most of the conducted studies compared the effects of organic and conventional fertilisers on the nutritive composition of products, but not the effects of the production system as a whole. A simple measurement of various nutrients in food does not reflect the food quality per se (Magkos, Arvaniti \& Zampelas, 2003). Results obtained by many researchers point out

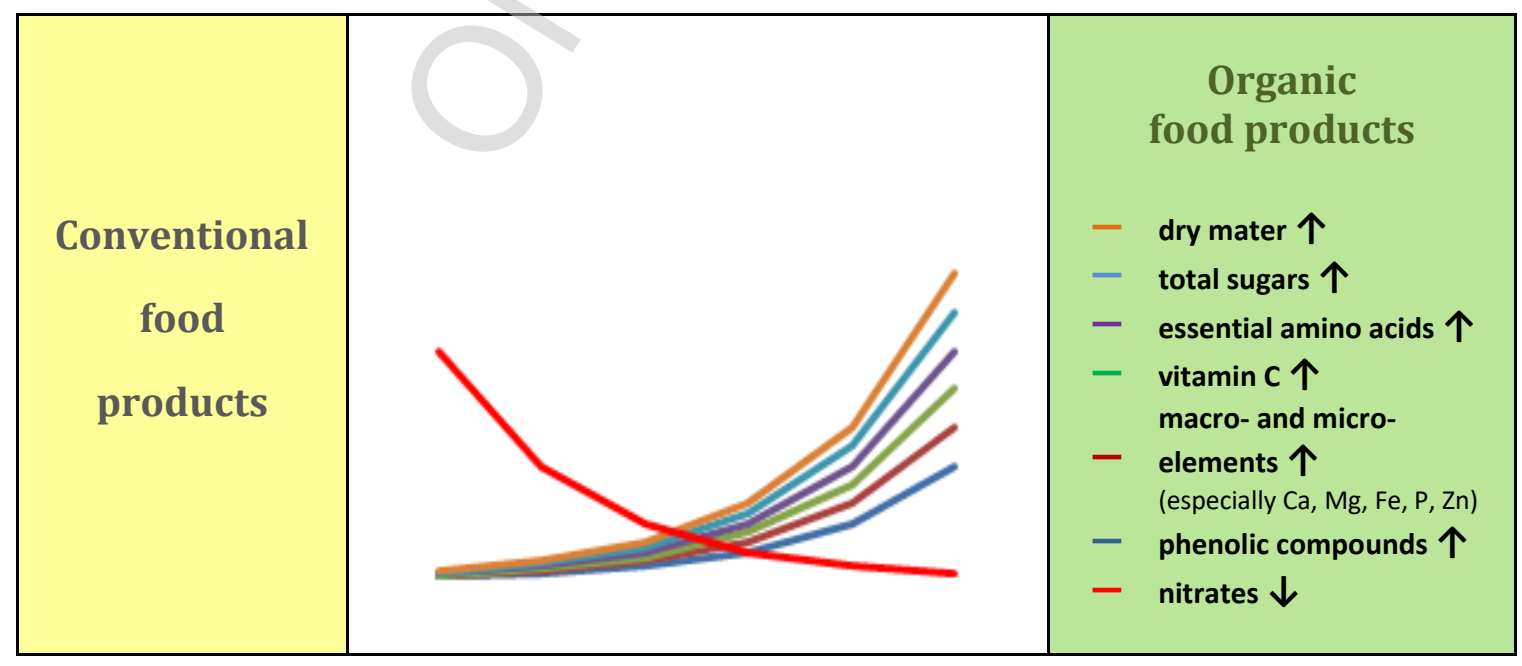

Figure 2. Effects of organic and conventional production methods on the chemical compositions of plants (data compiled from Woëse, Lange, Boess and Bogl, 1997; Worthington, 1998; Heaton, 2001; Worthington, 2001; Bourn and Prescott, 2002; Rembiałkowska, 2007; Baranski et al., 2014, and many others) 
that differences in the nutritional composition between organically and conventionally produced food products vary depending on the production season, plant species, morphological parts of plants being analysed, as well as on tested nutrients, so it is very difficult to draw a final conclusion on the effect of the cultivation system on the nutritional composition of plants (Magkos et al., 2003). Furthermore, several studies have proven that organically grown fruits and vegetables have a potentially higher nutritional value compared to conventional ones. Other studies have proven the existence of small differences or absence of differences, while several studies have indicated a higher level of specific nutrients in conventionally produced food products. Since many types of research suggest that the nutritional value of organic food is higher than the food conventionally produced, a clear consensus has not been reached yet and therefore, further studies are needed.

The aim of this study was to analyse the relevant literature and to point out the effects of organic and conventional methods of production on differences in the chemical composition of plants and their products in order to clarify ambiguities about favouring organically produced food.

\section{DRY MATTER}

Studies on the difference in dry matter contents between organic and conventional food products are mainly related to vegetables and fruits. Although obtained results vary, there are data that organically cultivated crops had a higher content of dry matter than conventionnally grown crops (Finesilver, Johns \& Hill, 1989; Hornick, 1992; Woëse et al., 1997; Worthington, 1998). According to some researches, organically grown leafy, root and tuber vegetables have a higher dry matter content than conventionally grown vegetables (Woëse et al., 1997; Bourn and Prescott, 2002; AFSSA, 2003), while no difference was detected in other types of vegetables and fruits. There are very limited data related to fruits, and they mainly refer to apples, strawberries, oranges, lemons, and pineapples. Higher content of dry matter was recorded in organic leafy vegetables, such as spinach, lettuce, chard, Savoy cabbage, and white cabbage than in conventional ones (Schuphan, 1974; Vogtmann, Temperli, Kunsch, Eichenberger \& Ott,
1984; Bourn, 1994; Lecerf, 1995; FjelknerModig, Bengtsson, Stegmark \& Nystrom, 2000). On the other hand, according to Schuphan (1974), Reinken (1986), Termine et al. (1987), Rembialkowska (1998), the differrences in this content were not recorded between organically and conventionally grown root vegetables, such as potatoes, leeks, turnips, and carrots. Stated differences in the dry matter content in two different production systems are related to the influence of nitrogen. As far back as 1972, Schuphan (1972) claimed that the increased application of nitrogen fertilisers could reduce the content of dry matter, methionine, total sugars, vitamin $\mathrm{C}$, essential oils, as well as, numerous minerals. As a result, the differences between organically and conventionally grown fruits are not expected due to the low ability of fruits to absorb and assimilate nitrogen. Bordeleau, Myers-Smith, Midak \& Szeremeta (2002) assumed that plants organically cultivated contained less dry matter than plants conventionnally produced, because the low amounts of fertilisers are applied in organic production and due to it plants are less developed and contain less water and thus less dry matter. Studies on the yield, quality indicators, antioxidants and elemental composition of nine leek cultivars grown in greenhouses under organic or conventional systems in the Moscow region, carried out by Golubkina et al. (2018), showed that pseudo-stem dry matter and sugars were higher with organic management.

\section{NITRATES}

Nitrate (NO3-) is the most important form of nitrogen $(\mathrm{N})$, which is easily absorbed by the majority of vegetables and fruits in order to achieve higher yields (Colla, Cardona Suarez, Cardanelli \& Rouphael, 2010). It is usually found in large quantities in green leafy vegetables such as lettuce and spinach, as well as, root vegetables such as celery, radishes and beets. When the intake of nitrate in the plant exceeds the assimilation, the nitrate is accumulated in the plant tissues. Higher concentrations of nitrates are accumulated in leaves, while the lower level of nitrates is accumulated in bulbs, seeds, fruits, roots and tubers. Therefore, leafy vegetables such as rocket, chard, spinach, lettuce, celery and parsley are considered to be nitrate-accumulating species (Santamaria, 2006). Factors that affect the accumulation of nitrates in plants are: lack of 
sunlight or water, variety, maturity and high levels of fertilisation (Wolff \& Wasserman, 1972). In contrast to a smaller number of data on the comparative dry matter content between organically and conventionally produced food products, the multitude of data indicates a lower nitrate content in organic crops (Worthington, 2001; Hoogenboom et al., 2008; Dangour et al., 2009; Soltoft et al., 2010; Gąstol, Domagała-Świątkiewicz \& Krośniak, 2011; Kalinova \& Vrchotova, 2011; Aires, Carvalho, Rosa \& Saavedra, 2012; Gorenjak, Koležnik \& Cencič, 2012; Koh, Charoenprasert \& Mitchell, 2012; Lombardo, Pandino \& Mauromicale, 2012; Tuomisto, Hodge, Riordan \& Macdonald, 2012; Ilić, Kapoulas, Sunic, Bekovic \& Mirecki, 2014; Nuñez de González et al., 2015; Rossetto, Vianello, Saeki \& Lima, 2015; Hallmann et al., 2017; Golubkina et al., 2018; Bender et al., 2020). It is of great importance to be aware of this fact, given that the harmful effects of nitrate on the human body are known. They can react with amines and form nitrosamines - carcinogenic and mutagenic substances that cause digestive tract cancer and leukaemia. Moreover, nitrates converted into nitrites cause methemoglobinemia (Fewtrell, 2004). The lower content of nitrates and a higher content of phenolic compounds and vitamin $\mathrm{C}$ in organic crops are vital for health because vitamin $\mathrm{C}$ interferes with the conversion of nitrate into toxic nitrites, which are the precursors of carcinogenic nitrosamines. Large amounts of polyphenols present in organically grown crops hinder the process of carcinogenesis (Rembiałkowska, 2007). Table 1 presents the comparative analysis of the nitrate and nitrogen content between organic and conventional systems. It is known that the use of organic fertilisers in crops can lead to lower nitrate levels in contrast to the application of nitrogen-rich mineral fertilisers (Leclerc, Miller, Joliet \& Rocquelin, 1991; Rembialkowska, 1998; Bourn \& Prescott, 2002). The content of nitrate in organic crops is lower, on average, by $49 \%$ than in conventional crops (Rembialkowska, 2000). According to the formula coined by Worthington (2001): (CONV-ORG) / ORG x 100\%, conventional crops contain an average of $148.39 \%$ more nitrate than organic crops. Consequently, the highest levels of nitrate were found in red beetroots. This is because they exhibit the tendency of nitrate accumulation in roots. It is generally known that the application of fertilisers in plant production affects the composition of plant material.

The majority of studies indicate that when a higher amount of nitrogen is available to a plant, its intake is higher, which results in a higher content of nitrogen and nitrates in crops (Bourn \& Prescott, 2002).

Table 1

Comparative analysis of nitrate and nitrogen content in plants from organic and conventional systems

\begin{tabular}{|c|c|c|c|}
\hline Reference & Samples & $\begin{array}{l}\text { Compounds } \\
\text { analysed }\end{array}$ & Major conclusions \\
\hline Worthington (2001) & $\begin{array}{l}\text { Many organic and } \\
\text { conventional crops }\end{array}$ & Nitrate & $\begin{array}{l}\text { Organic crops had a lower content of nitrate than } \\
\text { conventional crops. }\end{array}$ \\
\hline $\begin{array}{l}\text { Kramer, Reganold, } \\
\text { Glover, Bohannan \& } \\
\text { Mooney } \\
(2006)\end{array}$ & Apple orchard & $\mathrm{N}_{2} \mathrm{O}, \mathrm{N}_{2}$, nitrate & $\begin{array}{c}\text { Soils under organic management had higher organic } \\
\text { matter content, microbial biomass } \mathrm{C} \text { and } \mathrm{N} \text {. Annual } \\
\text { nitrate leaching was } 4.4-5.6 \text { times higher in } \\
\text { conventional than in organic fields. } \mathrm{N}_{2} \mathrm{O} \text { emissions } \\
\text { were not significantly different among treatments. } \\
\mathrm{N}_{2} \text { emissions were highest in organic fields. }\end{array}$ \\
\hline $\begin{array}{c}\text { Liu, Tu, Hu, } \\
\text { Gumpertz \& Ristaino } \\
\text { (2007) }\end{array}$ & $\begin{array}{l}\text { Conventional, organic } \\
\text { and sustainable farms }\end{array}$ & Nitrogen & $\begin{array}{l}\text { Soils from organic farms had improved soil chemical } \\
\text { factors and higher levels of extractable } \mathrm{C} \text { and } \mathrm{N} \text {, } \\
\text { higher microbial biomass carbon and nitrogen, and } \\
\text { net mineralizable } \mathrm{N} \text {. }\end{array}$ \\
\hline $\begin{array}{l}\text { Hoogenboom et al. } \\
\text { (2008) }\end{array}$ & $\begin{array}{l}\text { Lettuce, carrots, } \\
\text { potatoes }\end{array}$ & Nitrate & $\begin{array}{c}\text { Nitrate levels in organic lettuce were much lower } \\
\text { than those in conventional, while organic carrots and } \\
\text { organic potatoes showed a large variation. }\end{array}$ \\
\hline $\begin{array}{l}\text { Lima, lopes, Rossetto } \\
\text { \& Vianello } \\
(2009)\end{array}$ & $\begin{array}{l}\text { Chinese cabbage, } \\
\text { maize }\end{array}$ & Nitrate & $\begin{array}{l}\text { Higher concentration of nitrate was found in organic } \\
\text { production than conventional. }\end{array}$ \\
\hline Dangour et al. (2009) & $\begin{array}{l}\text { Many organic and } \\
\text { conventional crops }\end{array}$ & Nitrogen & $\begin{array}{l}\text { Nitrogen content was higher in crops from } \\
\text { conventional systems than organic. }\end{array}$ \\
\hline $\begin{array}{l}\text { Soltoft et al. } \\
(2010)\end{array}$ & Carrot & Nitrogen & $\begin{array}{l}\text { Higher concentration of nitrogen was detected in } \\
\text { conventional carrot than organic. }\end{array}$ \\
\hline
\end{tabular}




\begin{tabular}{|c|c|c|c|}
\hline Reference & Samples & $\begin{array}{l}\text { Compounds } \\
\text { analysed }\end{array}$ & Major conclusions \\
\hline $\begin{array}{l}\text { Gąstoł et al. } \\
\quad(2011)\end{array}$ & $\begin{array}{l}\text { Apple, pear, } \\
\text { blackcurrant,carrot, } \\
\text { beetroot and celery }\end{array}$ & $\mathrm{NH}_{4-}, \mathrm{NO}_{3-}$ & $\begin{array}{c}\mathrm{NH}_{4} \mathrm{~N} \text { content was lower in organic vegetable juices } \\
\text { than in conventional ones. The conventional farming } \\
\text { method favoured greater } \mathrm{NO}_{3} \mathrm{~N} \text { accumulation for } \\
\text { beetroot ( } 846 \mathrm{mg} \mathrm{NO} \mathrm{N} \mathrm{kg}^{-1} \text { f.w.) than for organic } \\
\text { juice }\left(229 \mathrm{mg} \mathrm{NO}_{3} \mathrm{~N} \mathrm{~kg}^{-1} \text { f.w.) }\right.\end{array}$ \\
\hline $\begin{array}{c}\text { Kalinova \& } \\
\text { Vrchotova } \\
(2011) \\
\end{array}$ & Buckwheat & Nitrate & $\begin{array}{l}\text { The nitrate content was higher in conventional } \\
\text { buckwheat compared with the organic buckwheat. }\end{array}$ \\
\hline $\begin{array}{l}\text { Gorenjak et al. } \\
\qquad(2012)\end{array}$ & Lettuce, dandelion & Nitrate & $\begin{array}{l}\text { The mean nitrate contents in organic lettuce were } \\
\text { considerably lower than those in conventional } \\
\text { sample. No major differences were recorded } \\
\text { between the dandelion samples. }\end{array}$ \\
\hline $\begin{array}{l}\text { Koh et al. } \\
(2012)\end{array}$ & 27 varieties of spinach & Nitrate & $\begin{array}{l}\text { The mean levels of nitrate were significantly higher } \\
\text { in the conventionally grown spinach compared to the } \\
\text { organically grown spinach. The levels of nitrate } \\
\text { correlated negatively with those of ascorbic acid, } \\
\text { vitamin C, and total flavonoids and showed a } \\
\text { positive correlation with the oxalate content. }\end{array}$ \\
\hline $\begin{array}{l}\text { Lombardo et al. } \\
\qquad(2012)\end{array}$ & Potato & Nitrate & $\begin{array}{l}\text { The nitrate content in the organic grown tubers was } \\
34 \% \text { less than in the conventional grown ones. }\end{array}$ \\
\hline $\begin{array}{l}\text { Tuomisto et al. } \\
\qquad(2012)\end{array}$ & $\begin{array}{l}\text { Many organic and } \\
\text { conventional crops }\end{array}$ & Nitrogen & $\begin{array}{l}\text { Nitrogen leaching per unit of area was } 31 \% \text { lower } \\
\text { from organic farming compared to conventional } \\
\text { farming. }\end{array}$ \\
\hline $\begin{array}{l}\text { Aires et al. } \\
\quad(2012)\end{array}$ & $\begin{array}{l}6 \text { kinds of baby-leaf } \\
\text { salads (red and green } \\
\text { lettuces, rucola, corn } \\
\text { salad, watercress, } \\
\text { chard) }\end{array}$ & Nitrite, nitra & $\begin{array}{l}\text { The nitrate average levels were significantly higher } \\
\text { in conventional products, while no significant } \\
\text { differences in nitrite content. }\end{array}$ \\
\hline $\begin{array}{l}\text { Laursen et al. } \\
\qquad(2013)\end{array}$ & Potato & Nitrate & $\begin{array}{l}\text { There were no significant differences between } \\
\text { farming systems, locations, or harvest years. }\end{array}$ \\
\hline Baranski et al. (2014) & $\begin{array}{l}\text { Many organic and } \\
\text { conventional crops }\end{array}$ & Total N & $\begin{array}{l}\text { Conventional crops had higher concentrations of } \\
\text { total N. }\end{array}$ \\
\hline $\begin{array}{c}\text { Ilić et al. } \\
(2014)\end{array}$ & Tomato & Nitrates & $\begin{array}{l}\text { Lower nitrate contents were observed in organic } \\
\text { products compared to conventional ones. }\end{array}$ \\
\hline $\begin{array}{l}\text { Rossetto et al. } \\
\qquad \text { (2015) }\end{array}$ & $\begin{array}{l}\text { Raw and cooked: } \\
\text { broccoli, collard } \\
\text { greens, carrot, beets }\end{array}$ & $\begin{array}{l}\text { Nitrate, } \\
\text { polyamines }\end{array}$ & $\begin{array}{l}\text { Nitrate contents showed significant difference } \\
\text { between conventional and organic broccolis, carrots, } \\
\text { and collard greens. Organic beets contained lower } \\
\text { nitrate levels compared to conventional beets. } \\
\text { Organic farming increased the polyamine levels and } \\
\text { decreased nitrate content. }\end{array}$ \\
\hline $\begin{array}{l}\text { Nuñez de González } \\
\text { et al. } \\
\text { (2015) }\end{array}$ & $\begin{array}{l}\text { Broccoli, cabbage, } \\
\text { celery, lettuce, } \\
\text { spinach }\end{array}$ & $\begin{array}{l}\text { Nitrate and } \\
\text { nitrite }\end{array}$ & $\begin{array}{l}\text { There was no difference in the average nitrite } \\
\text { contents of conventional vegetables compared to } \\
\text { organic vegetables. In most cases, organic vegetables } \\
\text { were numerically lower in nitrate content than their } \\
\text { conventional counterparts. }\end{array}$ \\
\hline $\begin{array}{l}\text { Kapoulas, } \\
\text { Koukounaras, \& Ilić } \\
(2017)\end{array}$ & Lettuce, onion & Nitrate & $\begin{array}{l}\text { In lettuce, the highest values of nitrate concentration } \\
\text { were in organic production system in autumn. The } \\
\text { nitrate concentration was significantly higher in } \\
\text { green onion plants grown during the spring period } \\
\text { compared to those grown in autumn, indicating that } \\
\text { different growing seasons affect nitrate content. } \\
\text { Onion from org. production system obtained higher } \\
\text { nitrate concentration. }\end{array}$ \\
\hline
\end{tabular}
Hallmann et al. White cabbage (2017)

Organic fresh cabbage, compared to the conventional one, contained significantly fewer nitrites and nitrates. 


\begin{tabular}{|c|c|c|c|}
\hline Reference & Samples & $\begin{array}{l}\text { Compounds } \\
\text { analysed }\end{array}$ & Major conclusions \\
\hline $\begin{array}{c}\text { Golubkina et al. } \\
(2018)\end{array}$ & Leek (Allium porrum) & Nitrate & $\begin{array}{l}\text { Nitrate concentration was higher with conventional } \\
\text { management. }\end{array}$ \\
\hline $\begin{array}{l}\text { Bender et al. } \\
\quad(2020)\end{array}$ & Carrot & $\begin{array}{l}\text { Nitrogen, } \\
\text { nitrate }\end{array}$ & $\begin{array}{l}\text { Carrots managed organically had } 14.1 \% \text { lower } \\
\text { nitrate than those managed conventionally. There } \\
\text { were no convincing effects of cultivation system on } \\
\text { the nitrogen or dry matter content of carrots. }\end{array}$ \\
\hline $\begin{array}{l}\text { Kwiatkowski \& } \\
\text { Harasim, } \\
\text { (2020) }\end{array}$ & $\begin{array}{l}\text { Crop rotations:potato- } \\
\text { winter wheat-field } \\
\text { bean-spring barley }\end{array}$ & $\begin{array}{l}\text { Total nitrogen } \\
\text { content, } \mathrm{N}_{-} \mathrm{NO}_{3} \\
\text { and } \mathrm{N}-\mathrm{NH}_{4}\end{array}$ & $\begin{array}{l}\text { Organic system contributed to an increased soil } \\
\text { content of and total nitrogen, also a higher soil } \\
\text { content of nitrogen in the form of } \mathrm{N}-\mathrm{NH}_{4} \text { and its } \\
\text { lower content in the form of } \mathrm{N}-\mathrm{NO}_{3} \text {. }\end{array}$ \\
\hline
\end{tabular}

If a plant receives more nitrogen than it can "withstand" through the increased protein synthesis, the remaining excess will be accumulated as nitrate and be stored mainly in green leafy parts of the plant (Mozafar, 1993; Worthington, 2001). Reganold and Wachter (2016) indicating that lower nutrient pollution from organic compared with conventional systems can be explaining by differences in their nitrogen cycling and losses.

Studies point out that the nitrogen levels in vegetable crops are higher when nitrogen is applied at high rates in the inorganic form than when nitrogen is applied in the form of compost or other organic fertilisers such as manure (Vogtmann et al., 1984; Woëse et al., 1997; Worthington, 1998). These and other data provide a basis for conclusions that organic practices result in reduced nitrate and nitrite intake in humans by approximately $50 \%$. Then, Vitamin $\mathrm{C}$ can afford protection from this conversion of nitrate to nitrite to nitrosamines. Due to it, the higher levels of nitrate in non-organic crops have often been linked with the lower vitamin C levels (Dlouhy, 1977; Fischer \& Richter, 1986; Lairon et al., 1986; Woëse et al., 1997; Worthington, 1998).

\section{PROTEINS}

The majority of studies related to the differrence in the protein content between organic and conventional crops refer to data on vegetables. Most authors have compared the contents of crude proteins and specific free amino acids. Few authors have studied protein quality, i.e. the composition of essential amino acids. Many authors have agreed that organically grown vegetables in comparison to conventionally grown vegetables, such as spinach, red beet, carrots, tomato and potato, had a lower content of crude proteins and free amino acids, and on the other hand had higher concentrations of several essential amino acids (Lairon et al., 1984; Millard, 1986; Reinken, 1986; Schuphan, 1974; Clarke \& Merrow, 1979; Eppendorfer, Eggum \& Bille, 1979; Bourn, 1994; Lecerf, 1995; Wawrzyniak, Kwiatkowski \& Gronowska-Senger, 1997; Woese et al., 1997; Kumpulainen, 2001; Bourn \& Prescott, 2002).

Pimpini, Giardini, Borin and Gianquinto (1992) compared the effects of the application of poultry manure and mineral fertilisers on the nutritional composition of potatoes, sugar beet, onion, tomatoes and spinach and have detected a lower content of crude proteins only in organically grown spinach. However, all differences in terms of quantity, type and quality of proteins in vegetable crops have very little practical significance, given their negligible (vegetables) or small (potatoes) contribution as a source of proteins.

Not much data are available on differences in protein contents between organic and conventional cereals and legumes. According to Woëse et al. (1997), organically grown cereals, especially wheat, contain fewer proteins than conventionally grown cereals. Organic cereals, such as wheat, maize and rye, tend to contain lower amounts of crude proteins and free amino acid, but higher amounts of essential amino acids (Dlouhy, 1977; Chakhovskii, 1981; Starling \& Richards, 1990; Starling \& Richards, 1993; Bourn, 1994; Ragasits \& Kismanyoky, 2000; Magkos et al., 2003).

Comparative studies performed by Shier, Kelman and Dunson (1984) on differences in contents of crude proteins, moisture and ash among nine samples of wheat from organic and conventional trials showed that the protein content obtained in both production systems was similar. Lower protein content in organic wheat can be a consequence of lower nitrogen 
availability (Starling \& Richards, 1990). Storey, Hogan and Humphreys (1993) studied the stability of wheat varieties for organic production and determined a lower content of proteins in them. On the other hand, according to some authors, organic wheat is nutritionally and metabolically superior (Bourn \& Prescott, 2002). The content of essential amino acid lysine was higher by $25-30 \%$ in organically grown wheat (Wolfson \& Shearer, 1981; Brandt, Brand \& Cruywagen, 2000). Regarding organic and conventional fruits, differences in the concentration of crude proteins and free amino acids are not significant (Reinken, 1986; Woese et al., 1997; Magkos et al., 2003). Since fruit is an insignificant source of proteins, these results have no practical importance. Contents of proteins, total sugars, total and insoluble fibres of conventional goji berries were significantly higher $(\mathrm{p} \leq 0.05)$ than those of organic goji berries (Pedro et al., 2019). Protein content varied from $9.57 \%$ in organic berries to $9.72 \%$ in conventional berries.

The higher content of crude proteins in conventionally grown vegetables is probably a consequence of the application of conventional fertilisers, which provided the plant with greater nitrogen availability than organic manure. It is known that the increased application of nitrogen in crop growing increases the concentration of crude proteins, but due to it, the nutritional protein value is reduced, i.e. the content of essential amino acids is decreased (Locascio, Wilkbank, Gull \& Maynard, 1984; Eppendorfer \& Eggum, 1996; Worthington, 2001; Rembialkowska, 2007), in particular the lysine content (Worthington, 2001). The response of each amino acid to the application of nitrogen fertilisers differs in dependence on the crop variety. The application of greater amounts of nitrogen fertilisers in organically and conventionally grown maize increased the contents of lysine, methionine, histidine and threonine, and decreased the contents of isoleucine, leucine and phenyllanine in organic maize. The content of crude proteins increased in the conventionally grown crop, while no differrence in the proportion of amino acids was detected (Lockeretz, Shearer \& Kohl, 1981; Wolfson \& Shearer, 1981).

\section{SUGARS}

The majority of previously conducted studies indicate that organically grown crops and their products have a higher content of total sugars.
The comparative analysis of the sugar contents between organic and conventional systems is presented in Table 2.

A higher content of total sugars, most often saccharose, was found in organically grown vegetables (carrots, sugar beet, red beet, potato, spinach, Savoy cabbage) and fruits (apple, cherry, current) (Rembiałkowska, 2000; Bordeleau et al., 2002). The higher content of total sugars in organically grown fruits affects the better consumers' taste perception (Rembialkowska, 2000). Hogstad, Risvik and Steinsholt (1997) performed trials on 14 farms and compared the contents of dry matter, carotene, proteins, nitrates, sugars, as well as, sensory quality of carrots. These authors determined that organically grown carrots were much juicier, sweeter, and crispier, furthermore contained more total flavour strength than conventionally grown carrots. Organic carrots also had a significantly higher content of dry matter, true protein, total sugars and carotene. Although amounts of sugars were higher in organically grown crops (Bøhn et al., 2014), some authors observed no effects of either organical or conventional management on the sugar content in crops (Zörb, Langenkämper, Betsche, Niehaus \& Barsch, 2006; Langenkämper et al., 2006). According to Pither and Hall (1990), who compared the nutritional content of organic and conventional vegetables, conventionally grown carrots had a higher content of glucose, fructose, total sugars and vitamin $\mathrm{C}$, the organic potato had a higher content of glucose, fructose, $\mathrm{Ca}, \mathrm{Fe}$ and $\mathrm{Zn}$, while conventional potato contained more dry matter and saccharose.

Studying differences among nine leeks cultivars (Allium porrum) grown in greenhouses under organic and conventional systems, Golubkina et al. (2018) concluded that the contents of sugars and dry matter were higher in organic leek cultivars. A significant positive correlation was determined between dry matter and disaccharides, while the correlation between dry matter and monosaccharides was negative. The increased content of dry matter and sugar in organic leek may be a consequence of the enhancement of microbial biomass and activity leading to the synthesis of the organic compounds, which is in agreement with similar studies carried out in greenhouses (Caruso, Villari, Borrelli \& Russo, 2012). Indeed, Ca- 
ruso et al. (2012) performed a three-year study (2007-2009) on green asparagus under the tunnel in Campania, and reported that the level of residues and sugars were higher in organic asparagus whereas nitrate and fibres levels were lower. According to studies carried out - by Pedro et al. (2019), the contents of proteins, total sugars, total and insoluble fibres of conventional goji were significantly higher than those of organic goji Both berries of organic and conventional goji are a great source of carbohydrates and important food in the diet.

Table 2.

Comparative analysis of sugar content in plants from organic and conventional systems

\begin{tabular}{cccc}
\hline Reference & Samples & $\begin{array}{c}\text { Compounds } \\
\text { analysed }\end{array}$ & Major conclusions \\
\hline $\begin{array}{c}\text { Kumpulainen } \\
(2001)\end{array}$ & Carrots, potatoes & Sugars & For organic acids and sugars, no clear difference was \\
found.
\end{tabular}

\begin{tabular}{clcc}
\hline $\begin{array}{c}\text { Reganold, Glover, } \\
\text { Andrews \& Hinman } \\
\text { (2001) }\end{array}$ & Apple & Sugars & $\begin{array}{c}\text { The ratio of soluble solids (sugar) content to acidity } \\
\text { (tartness), an indication of sweetness, the highest in } \\
\text { organic fruit. }\end{array}$ \\
\hline $\begin{array}{c}\text { Zörb et al. } \\
\text { (2006) }\end{array}$ & Wheat grain & $\begin{array}{c}\text { Sugars, sugar } \\
\text { alcohols, sugar } \\
\text { phosphates }\end{array}$ & $\begin{array}{c}\text { No significant differences in glucose, fructose, } \\
\text { saccharose, maltose, and erythrose-4-P of organic } \\
\text { and conventional wheat were detected. Though } \\
\text { small, differences were detected in myoinositol } \\
\text { content which was reduced in grains from the } \\
\text { conventional system. }\end{array}$ \\
\hline $\begin{array}{c}\text { Langenkämper et al. } \\
(2006)\end{array}$ & Wheat & Fructan & $\begin{array}{c}\text { Fructan-levels were equal in wheat from organic and } \\
\text { conventional farming systems. }\end{array}$ \\
\hline
\end{tabular}

\begin{tabular}{|c|c|c|c|}
\hline $\begin{array}{l}\text { Wang, Chen, } \\
\text { Sciarappa, Wang \& } \\
\text { Camp } \\
\text { (2008) }\end{array}$ & Blueberries & Sugars & $\begin{array}{l}\text { Blueberry fruit grown from organic culture yielded } \\
\text { significantly higher sugars (fructose and glucose) } \\
\text { than fruit from the conventional culture. }\end{array}$ \\
\hline $\begin{array}{l}\text { Zörb, Niehaus, } \\
\text { Barsch, Betsche \& } \\
\text { Langenkämper } \\
\text { (2009) }\end{array}$ & Wheat ears & $\begin{array}{l}\text { Sugars, sugar } \\
\text { alcohols }\end{array}$ & $\begin{array}{l}\text { In ears, no significant differences between the } \\
\text { farming systems with regard to kestotetraose, } \\
\text { kestopentaose, stachyose, maltose, 1-kestose, } \\
\text { raffinose, and fructose were detected. Only a } \\
\text { difference for sucrose and glucose was found with } \\
\text { higher concentrations in ears from conventional } \\
\text { agriculture. }\end{array}$ \\
\hline $\begin{array}{l}\text { Gąstoł et al. } \\
\text { (2011) }\end{array}$ & Beetroot & Sugars & $\begin{array}{l}\text { Higher total sugars were noted for organic than } \\
\text { conventional beetroot }(8.4 \% \text { versus } 5.9 \%) \text {. }\end{array}$ \\
\hline $\begin{array}{l}\text { Carillo, Cacace, De } \\
\text { Pascale, Rapacciuolo } \\
\text { \& Fuggi } \\
\text { (2012) }\end{array}$ & Potato & $\begin{array}{l}\text { Carbohydrate, } \\
\text { starch }\end{array}$ & $\begin{array}{l}\text { Compared with organic potatoes, total carbohydrate } \\
\text { and starch content were much higher in conventional } \\
\text { potatoes. }\end{array}$ \\
\hline $\begin{array}{l}\text { Skrabule, Muceniece, } \\
\text { \& Kirhnere } \\
\text { (2013) }\end{array}$ & Potato & Starch & $\begin{array}{l}\text { No significant correlations with starch content were } \\
\text { found between potatoes grown in organic and } \\
\text { conventional fields. }\end{array}$ \\
\hline $\begin{array}{l}\text { Nunes-Damaceno, } \\
\text { Muñoz-Ferreiro, } \\
\text { Romero-Rodríguez \& } \\
\text { Vázquez-Odériz } \\
\text { (2013) } \\
\end{array}$ & Kiwis & Sugars & $\begin{array}{l}\text { Conventional kiwis showed a higher content of } \\
\text { sugars than organic kiwis, and had the greatest } \\
\text { soluble solids, glucose and fructose contents. } \\
\text { Conventional kiwis were larger in size and weight, } \\
\text { and had a sweeter taste than organic kiwis. }\end{array}$ \\
\hline $\begin{array}{l}\text { Bøhn et al. } \\
\text { (2014) }\end{array}$ & Soybeans & Sugars & $\begin{array}{l}\text { Organic soybeans showed the healthiest nutritional } \\
\text { profile with more sugars, such as glucose, fructose, } \\
\text { sucrose and maltose, significantly more total protein } \\
\text { and less fibre than both conventional and GM-soy. }\end{array}$ \\
\hline $\begin{array}{c}\text { Kouřimská, } \\
\text { Kubaschová \& Sus } \\
(2014) \\
\end{array}$ & Carrot & Sugars & $\begin{array}{l}\text { Organic grown carrot had higher contents of glucose, } \\
\text { fructose and saccharose than carrots grown in the } \\
\text { integrated farming system. }\end{array}$ \\
\hline $\begin{array}{l}\text { Brazinskiene et al. } \\
\text { (2014) }\end{array}$ & Potato & Starch & $\begin{array}{l}\text { Potatoes from organic and conventional systems had } \\
\text { similar starch content. }\end{array}$ \\
\hline $\begin{array}{l}\text { Bach, Kidmose, } \\
\text { Kristensen \& } \\
\text { Edelenbos (2015) } \\
\end{array}$ & Carrot & Sugars & $\begin{array}{l}\text { Sugar concentration was similar between organic } \\
\text { and conventional carrots. }\end{array}$ \\
\hline
\end{tabular}




\begin{tabular}{|c|c|c|c|}
\hline Reference & Samples & $\begin{array}{c}\text { Compounds } \\
\text { analysed }\end{array}$ & Major conclusions \\
\hline $\begin{array}{l}\text { Suja, Byju, Jyothi, } \\
\text { Veena, \& Sreekumar } \\
\text { (2017) }\end{array}$ & Taro & Sugars & $\begin{array}{c}\text { Organic taro had higher starch }(10.78 \%) \text {, total } \\
(31.55 \%) \text { and reducing sugars }(9.37 \%) \text { than } \\
\text { conventional crops. }\end{array}$ \\
\hline $\begin{array}{l}\text { Golijan et al. } \\
\text { (2017a) }\end{array}$ & $\begin{array}{l}\text { Soybean, maize, spelt, } \\
\text { buckwheat }\end{array}$ & Sugars & $\begin{array}{c}\text { Conventionally growing cultivars soybean and spelt } \\
\text { had higher sugars content. Organically maize and } \\
\text { buckwheat contained more soluble sugars than } \\
\text { conventional cultivars. }\end{array}$ \\
\hline $\begin{array}{c}\text { Golubkina et al. } \\
\text { (2018) }\end{array}$ & Leek & Sugars & $\begin{array}{l}\text { When cultivated with organic procedures, all } \\
\text { cultivars attained higher dry matter and sugar. }\end{array}$ \\
\hline $\begin{array}{l}\text { Pedro et al. } \\
\text { (2019) }\end{array}$ & Goji berry & Sugars & $\begin{array}{l}\text { The content of total sugars, total and insoluble fibres } \\
\text { of conventional goji were significantly higher than } \\
\text { that of organic goji. The content of fructose was } \\
\text { greater in organic goji, while, the content of glucose } \\
\text { was greater in conventional goji. }\end{array}$ \\
\hline $\begin{array}{l}\text { Reche et al. } \\
\text { (2019) }\end{array}$ & Jujube fruit & Sugars & $\begin{array}{l}\text { Organic jujubes were smaller, with higher contents } \\
\text { of sugars than conventional jujubes. }\end{array}$ \\
\hline $\begin{array}{l}\text { Zhang et al. } \\
\text { (2019) }\end{array}$ & Wheat & Sugars & $\begin{array}{l}\text { In this study, the contents of sugars and their } \\
\text { derivatives, including glucose, maltose, trehalose, } \\
\text { threitol, xylitol, and sorbitol, were higher in organic } \\
\text { wheat grains than in conventional grown wheat } \\
\text { grains. }\end{array}$ \\
\hline $\begin{array}{l}\text { Bender et al. } \\
\text { (2020) }\end{array}$ & Carrot & Sugars & $\begin{array}{l}\text { There were no convincing effects of cultivation } \\
\text { system on the total sugar content of carrots. }\end{array}$ \\
\hline $\begin{array}{l}\text { Golijan } \\
(2020 a)\end{array}$ & $\begin{array}{l}\text { Maize, spelt, soya } \\
\text { bean }\end{array}$ & $\begin{array}{l}\text { Total soluble } \\
\text { sugars, } \\
\text { individual } \\
\text { sugars, starch }\end{array}$ & $\begin{array}{c}\text { No effect of the cultivation method was observed on } \\
\text { the content of total soluble sugars in maize and spelt. } \\
\text { A higher amount of total soluble sugars was in } \\
\text { conventionally grown soya bean. Starch was higher } \\
\text { in organically soya bean. Organically grown maize } \\
\text { had higher non-reducing disaccharides, while } \\
\text { conventionally maize contained more } \\
\text { monosaccharides. }\end{array}$ \\
\hline
\end{tabular}

The content of available carbohydrates (total su-gars) ranged from $67.85 \%$ in organic goji to $75.05 \%$ in conventional goji. Fructose was the most important soluble sugar identified in organic and conventional fruits (5.45 and 4.92 $\mathrm{g} / 100 \mathrm{~g}$, respectively), followed by glucose and sucrose.

According to Zörb et al. (2006), who observed different types of metabolites and sugars in organically and conventionally grown wheat, there were no significant effects of the production methods on the amount of sugar in wheat. An inverse correlation between the amount of starch and protein in wheat grain has been established in the study performed by Konvalina, Stehno, Capouchová and Moudry (2011) according to which the increase in the starch amount in grain was caused by conditions unfavourable for the protein accumulation in grain.

Organic potato has higher con-tents of glucose and fructose, while the con-ventionally grown potato contains higher amounts of saccharose (Warman \& Harvard, 1998).
Kouřimská et al. (2014) stated that carrots grown in the organic farming system had higher contents of glucose, fructose and saccharose than carrots grown in the integrated farming system. Similar results have been gained by Golijan (2020a), who observed the effects of organic and conventional farming on the contents of total soluble sugars, individual sugars and starch in seeds of maize, spelt wheat and soya bean. In seeds of maize and spelt wheat, no effect of the cultivation method was observed on the content of total soluble sugars; the differences were seasonal. A higher amount of total soluble sugars was established in conventionally grown soya beans, while the detected amount of starch was higher in organically grown soya beans. Seeds of organically grown maize are characterised by a higher presence of non-reducing disaccharides. On the other hand, seeds of conventionally grown maize contained more monosaccharides. Moreover, Golijan et al. (2017a) established higher contents of soluble sugars in seeds of organically grown maize and buck- 
wheat in comparison to those grown conventionally.

Summarising the results of 150 studies related to the effects of organic and conventional farming systems on the chemical compositions of food products, Woëse et al. (1997) concluded that there was no difference in the content of total sugars, starch and monosaccharides. There was no difference in the contents of total organic acids, as well as, malic and oxalic acids in red beet, carrot, spinach, leek and celery. Furthermore, the absence of evidence of a significant difference in the contents of sugar and organic acids between organically and conventionally grown strawberries, apples and pineapples is in line with the report of Alvarez, Carracedo, Iglesias and Martinez (1993). Since the contents of acids, sugars and dry matter in fruits vary among species grown in the same farming system that is affected by microclimate, maturity/ripeness and other factors, it is very difficult to determine differences caused by different methods of fruit production (Bordeleau et al., 2002).

One of the reasons for higher sugar contents in organic foods is the effect of nitrogen. Namely, the higher amount of nitrogen that reaches the plant through the higher rates of nitrogen fertilisers applied in the conventional crop production reduces the amount of dry matter, total sugars, methionine, numerous mineral elements and vitamin C (Bourn \& Prescott, 2002).

\section{VITAMINS}

A large number of studies refer to the differences in the vitamin contents between organic and conventional food products. However, a clear consensus does not exist yet. It can only be stated with certainty that organic food products contain higher quantities of vitamin $\mathrm{C}$. The contents of vitamin $\mathrm{C}$, all groups of secondary metabolites not including carotenes and some other compounds such as anthocyanins, tocopherols and volatile substances, were higher in plants organically grown in comparison to plants conventionally grown. Table 3 presents the comparative analysis of the contents of vitamins and pigments between organic and conventional systems.

According to the meta-analysis of results referring to the contents of secondary metabolites and vitamins, it is obvious that these contents are higher in organically grown fruits and vegetables, particularly the vitamin $\mathrm{C}$ content, which is higher by 6\% (Brandt, Leifert, Sanderson \& Seal, 2011). Moreover, Smith-Spangler et al. (2012), based on the meta-analysis of 17 studies in humans and 223 studies of nutrient and contaminant levels in foods, have stated that there was strong evidence that organic foods were significantly more nutritious than conventional foods. These authors have not established significant differences for vitamin C (31 studies), $\beta$-carotene (12 studies) and $\alpha$-tocopherol (5 studies). A similar report was submitted by Baranski et al. (2014). These authors established statistically significant differences for a small number of carotenoids and vitamins. Moreover, they stated that there were higher concentrations of xanthophylls and Lascorbic acid and lower concentrations of vitamin E (higher concentrations of total carotenoids, carotenoids and lutein) in organic food products.

Summarising the findings of other authors, Worthington (2001) reported that the content of vitamin $\mathrm{C}$ contained in organic foods was higher by $27 \%$ than in conventional ones. Similar statements were also made earlier by Worthington (1998). It has been proven that the amounts of vitamin $\mathrm{C}$ are somewhat higher in organically grown leafy vegetables and potatoes. The higher vitamin $\mathrm{C}$ content has been determined in organic potatoes (Kolbe, Meineke \& Zhang, 1995), tomatoes (Pither \& Hall, 1990; Caris-Veyrat et al., 2004), celery and kale (Leclerc et al., 1991). Contrary to findings suggesting that the vitamin $\mathrm{C}$ content is higher in organic food products, many researchers reported no differences in the vitamin $\mathrm{C}$ content between organically and conventionally grown vegetables (Lairon et al., 1986; Warman \& Havard, 1996; Warman \& Havard, 1998; Rembialkowska, 1998; Fjelkner-Modig et al., 2000).

On the other hand, Auclair, Zee, Karam and Rochat (1995) have stated that organically grown vegetables contained a lower amount of this vitamin. Some studies reported higher vitamin C levels in conventional products (Clarke \& Merrow, 1979; Hansen, 1981). According to studies carried out by Weibel, Bickel, Leuthold and Alföldi (2000), a significantly higher P content (31.9\%), higher technical and vital quality (14.7\% and $65.7 \%$, respectively), were established in apples in orga- 
nic farming. Furthermore, these apples contained more phenolic compounds (18.6\%) and were of better taste $(15.4 \%)$. On the other hand, contents of minerals $\mathrm{K}, \mathrm{Ca}, \mathrm{Mg}$ and $\mathrm{Se}$, as well as vitamins $\mathrm{C}$ and $\mathrm{E}$, did not significantly differ, neither did animals show feeding preference, nor did the fruits degrade faster. No difference in the contents of vitamins $\mathrm{C}, \mathrm{B} 1$ and B2, minerals, carbohydrates, proteins and free amino acids, as well as, organic acids were found between organic and conventional fruits (apples, pineapples and strawberries) (Alvarez et al., 1993; Woëse et al., 1997). Regarding the contents of vitamins in cereals, differences in the vitamin B complex content between organic and conventional farming systems have not been established (Woëse et al., 1997). In contrast, higher vitamin C levels were observed by many authors (Leclerc et al., 1991; Warman \& Havard, 1996; Woëse et al., 1997; Warman \& Havard, 1998; Worthington, 1998; Xu, Wang, Mridha, Goyal \& Umemura, 2000; Worthington, 2001).

The content of vitamin $\mathrm{C}$ in fruits and vegetables depends on many factors, such as a genotype, weather conditions before harvest, cropping practices, harvest method and treatments after harvest (Lee \& Kader, 2000). The accumulation of vitamin $\mathrm{C}$ is related to the impact of stress factors on plants that induce oxidative stress in plant tissues, such as high temperatures and increased light, drought, and low nitrogen availability in the soil (Brandt \& Mølgaard, 2001). The higher content of vitamin $\mathrm{C}$ in the organic crop may be caused by the crop insufficient maturity at harvest. Since the level of vitamin $\mathrm{C}$ is affected by numerous factors, one should be careful when interpretting results as well as drawing any conclusions. For instance, light is an important factor that affects the content of vitamin $\mathrm{C}$ in tomatoes. It has been shown that the fruits exposed to direct sunlight had higher vitamin $\mathrm{C}$ levels compared to those with shaded leaves (Clarke \& Merrow, 1979). In addition, the effects of nitrogen on vitamin $\mathrm{C}$ content are known. The extensive use of nitrogen fertilisers increases the contents of nitrates and thus reduces the contents of vitamin $\mathrm{C}$ in vegetables and fruits (Mozafar, 1996; Bourn \& Prescott, 2002). Numerous studies are indicate that fertilisation tends to decrease vitamin $\mathrm{C}$ levels (Lee \& Kader, 2000) and to increase $\beta$ carotene levels (Mozafar, 1993). Mineral nutrition with nitrogen fertilisers is positively correlated with $\beta$-carotene levels (Brandt \& Mølgaard, 2001). Nitrogen from conventional mineral fertilisers affects the contents of vitamin $\mathrm{C}$ and nitrates in plants. Namely, when the plant is supplied with high amounts of nitrate, it increases protein production, but, simultaneously, it decreases sugar production. As vitamin $\mathrm{C}$ is known to be synthesised from sugar, nitrites will reduce the synthesis of vitamin C. If the plant is supplied with more nitrogen than it can "withstand" through the increased protein synthesis, the remaining excess will be accumulated in the form of nitrates and be stored mainly in green leafy parts of the plant (Mozafar, 1993; Worthington, 2001). According to some studies, reduced amounts of nitrogen can result in an increased accumulation of phenolic compounds, but, on the other hand, higher amounts of nitrogen fertilisers improve the formation of chlorophylls and carotenoids (Schreiner, 2005).

There is a large body of data on the differences in the vitamin $\mathrm{C}$ content between organic and conventional food products. Data on the contents of other vitamins, such as $\beta$-carotene (precursor of vitamin A), B1 and B2 are contradictory; hence a general conclusion cannot be drawn. Higher levels of vitamin E were found in organic olive oil (Gutierrez, Arnaud \& Albi, 1999). Regarding contents of vitamins $\mathrm{A}, \mathrm{B} 1$ and $\mathrm{B} 2$, no significant differences were observed between organic and conventional vegetables (Clarke \& Merrow, 1979; Bourn, 1994; Lecerf, 1995; Warman \& Havard, 1996; Woese et al., 1997; Warman \& Havard, 1998; Kumpulainen, 2001; Bourn \& Prescott, 2002), fruits (Magkos et al., 2003) and cereals (Woëse et al., 1997). For instance, according to the report by Kumpulainen (2001), no significant differences were established in the contents of $\beta$-carotene, vitamins B1 and B2 in organic carrots and potatoes whereas Leclerc et al. (1991) detected higher levels of $\beta$-carotene and vitamin B1 in organic carrots.

According to Golubkina et al. (2018), the ascorbic acid content was higher in all nine organic leek cultivars than in conventional ones. Ribes-Moya, Raigón, Moreno-Peris, Fita \& Rodríguez-Burruezo (2018) carried out studies on 37 accessions of Spanish landraces and introduced material of hot peppers and other 
species grown within organic and conventional systems, in order to evaluate ascorbic acid, total phenolics and total red and yellow/orange carotenoids, considering both ripening stages. A significant genotypic variation was established for the studied traits within each ripening stage and growing condition. According to these authors, differences in carotenoids were not attributed to growing conditions but principally to the genotype factor.

Crops treated with mixed fertilisers were found to have more $\beta$-carotene and minerals but lower levels of B vitamins than crops grown organically (Williams, 2002). Ismail and Fun (2003) have analysed the contents of $\beta$-carotene, vitamin $\mathrm{C}$ and riboflavin in vegetables (Brassica juncea, Brassica alboglabra, Lactuca sativa, Amaranthus viridis, Ipomoea aquatica) and found that only Ipomoea aquatica grown organically had the highest contents of $\beta$-carotene, riboflavin and vitamin $\mathrm{C}$ among the entire samples studied. Organic tomato contains more $\beta$-carotene (Caris-Veyrat et al., 2004). $\beta$-carotene is contained within chloroplasts and acts as an antioxidant, performing specific roles during the process of energy transfer. During fruit development, light leads to an increase in the contents of carotenes and carotenoids (McCollum, 1956), and care must be taken when interpreting results. Moreover, the $\beta$-carotene content is reduced under conditions of reduced chloroplast proliferation, which usually occurs when the availability of nitrogen is limited. In plants such as carrots or pumpkins in which carotenoids perform the function of colourants in certain plant organs, their contents reach the maximum values under conditions that are optimal for the growth of these plants (Brandt \& Mølgaard, 2001).

The content of vitamin $\mathrm{C}$ in fruits and vegetables depends on many factors, such as a genotype, weather conditions before harvest, cropping practices, harvest method and treatments after harvest (Lee \& Kader, 2000).

The accumulation of vitamin $\mathrm{C}$ is related to the impact of stress factors on plants that induce oxidative stress in plant tissues, such as high temperatures and increased light, drought, and low nitrogen availability in the soil (Brandt \& Mølgaard, 2001).

Table 3.

Comparative analysis of vitamins and pigments levels in plants from organic and conventional systems

\begin{tabular}{|c|c|c|c|}
\hline Reference & Samples & $\begin{array}{c}\text { Compounds } \\
\text { analysed }\end{array}$ & Major conclusions \\
\hline $\begin{array}{l}\text { Worthington } \\
\text { (2001) }\end{array}$ & $\begin{array}{l}\text { Many organic and } \\
\text { conventional crops }\end{array}$ & Vitamin C & $\begin{array}{l}\text { Vitamin } C \text { contained in organic foods was higher } \\
\text { by } 27 \% \text { than in conventional ones. }\end{array}$ \\
\hline $\begin{array}{l}\text { Kumpulainen } \\
\text { (2001) }\end{array}$ & Carrots, potatoes & $\begin{array}{c}\beta \text {-carotene, } \\
\text { vitamins B1, B2 }\end{array}$ & $\begin{array}{l}\text { No significant differences were established in the } \\
\text { contents of } \beta \text {-carotene, vitamins B1 and B2 in } \\
\text { organic carrots and potatoes. }\end{array}$ \\
\hline $\begin{array}{l}\text { Carbonaro, Matterra, } \\
\text { Nicoli, Bergamo \& } \\
\text { Cappelloni } \\
(2002)\end{array}$ & Peaches, pears & $\begin{array}{l}\text { Ascorbic acid, } \\
\text { tocopherols }\end{array}$ & $\begin{array}{l}\text { Ascorbic acid was higher in organic compared to } \\
\text { conventional peaches. Higher tocopherol levels } \\
\text { were found in organic pears than in those produced } \\
\text { under conventional system. }\end{array}$ \\
\hline $\begin{array}{l}\text { Asami, Hong, } \\
\text { Barrett\& Mitchell } \\
\quad(2003)\end{array}$ & $\begin{array}{l}\text { Marionberry, } \\
\text { strawberry, corn }\end{array}$ & Ascorbic acid & $\begin{array}{l}\text { Levels of ascorbic acid in organically grown and } \\
\text { sustainably grown samples were consistently } \\
\text { higher than the levels for the conventionally grown } \\
\text { crops. }\end{array}$ \\
\hline $\begin{array}{c}\text { Lombardi-Boccia, } \\
\text { Lucarini, Lanzi, } \\
\text { Aguzzi \& Cappelloni } \\
\text { (2004) } \\
\end{array}$ & Yellow plums & $\begin{array}{l}\text { Ascorbic acid, } \\
\text { vitamin E, } \\
\beta \text {-carotene }\end{array}$ & $\begin{array}{l}\text { Ascorbic acid, alpha-, gamma-tocopherols, and } \\
\text { beta-carotene were higher in organic plums grown } \\
\text { on soil covered with natural meadow. }\end{array}$ \\
\hline $\begin{array}{c}\text { Chassy, Bui, Renaud, } \\
\text { Van Horn \& Mitchell } \\
\text { (2006) }\end{array}$ & Tomatoes, bell peppers & Ascorbic acid & $\begin{array}{c}\text { Ascorbic acid (16\%) was higher in organic } \\
\text { tomatoes. }\end{array}$ \\
\hline $\begin{array}{l}\text { Koh, Wimalasiri, } \\
\text { Renaud \& Mitchell } \\
\text { (2007) }\end{array}$ & Marinara pasta sauces & $\begin{array}{l}\text { Vitamin C, } \\
\beta \text {-carotene }\end{array}$ & $\begin{array}{l}\text { The content of total vitamin } C \text { was not statistically } \\
\text { different between organic and conventional } \\
\text { samples. Conventional pasta sauces demonstrated } \\
\text { a significantly higher level of all-trans- } \beta \text {-carotene. }\end{array}$ \\
\hline $\begin{array}{l}\text { Reganold et al. } \\
\text { (2010) }\end{array}$ & Strawberries & Ascorbic acid & $\begin{array}{l}\text { Organic strawberries had higher ascorbic acid } \\
(9.7 \%) \text { than conventional berries. }\end{array}$ \\
\hline $\begin{array}{l}\text { Brandt et al. } \\
\text { (2011) }\end{array}$ & $\begin{array}{l}\text { Many organic and } \\
\text { conventional crops }\end{array}$ & Vitamin C & $\begin{array}{l}\text { Vitamin C was higher in organic than conventional } \\
\text { samples. }\end{array}$ \\
\hline
\end{tabular}




\begin{tabular}{|c|c|c|c|}
\hline Reference & Samples & $\begin{array}{c}\text { Compounds } \\
\text { analysed }\end{array}$ & Major conclusions \\
\hline $\begin{array}{l}\text { Koh et al. } \\
\text { (2012) }\end{array}$ & 27 Varieties of spinach & Vitamin C & $\begin{array}{l}\text { No significant difference was reported between the } \\
\text { spinaches on vitamin } C \text { contents. }\end{array}$ \\
\hline $\begin{array}{l}\text { Lombardo et al. } \\
\qquad(2012)\end{array}$ & Potato & Ascorbic acid & $\begin{array}{c}\text { Ascorbic acid level in conventionally grown } \\
\text { potatoes was } 23 \% \text { higher than that in organic } \\
\text { potatoes. }\end{array}$ \\
\hline Skrabule et al. (2013) & Potato & $\begin{array}{l}\text { Vitamin } \mathrm{C}, \\
\text { vitamins B1, B2 }\end{array}$ & $\begin{array}{l}\text { The vitamin B1 concentration of potato genotypes } \\
\text { grown in the organic field exceeded that of potato } \\
\text { genotypes grown in the conventional field. }\end{array}$ \\
\hline $\begin{array}{l}\text { Hallmann, Lipowski, } \\
\text { Marszałek \& } \\
\text { Rembiałkowska } \\
\text { (2013) }\end{array}$ & Tomato juice & $\begin{array}{l}\text { Vitamin } C, \\
\beta \text {-carotene }\end{array}$ & $\begin{array}{l}\text { The organic tomato juice contained significantly } \\
\text { more } \beta \text {-carotene compared to the non-organic } \\
\text { tomato juice. Non-organic tomato juice was } \\
\text { characterized by a significantly higher content of } \\
\text { vitamin } \mathrm{C}(19.30 \mathrm{mg} / 100 \mathrm{~g} \text { f.w. }) \text { in comparison } \\
\text { with the organic juice ( } 16.80 \mathrm{mg} / 100 \mathrm{~g} \text { f.w.). }\end{array}$ \\
\hline $\begin{array}{l}\text { Oliveira et al. } \\
(2013)\end{array}$ & Tomato & Vitamin C & $\begin{array}{l}\text { Higher vitamin } \mathrm{C} \text { were detected in organic } \\
\text { compared to conventional tomatoes at harvest. }\end{array}$ \\
\hline $\begin{array}{l}\text { Tõnutare, Keert, } \\
\text { Szajdak \& Moor } \\
\text { (2014) }\end{array}$ & Strawberry & $\begin{array}{l}\text { Ascorbic acid, } \\
\text { vitamin E }\end{array}$ & $\begin{array}{l}\text { There is no evidence supporting that organically } \\
\text { harvested strawberries have more bioactive } \\
\text { compounds compared with conventional } \\
\text { strawberries. }\end{array}$ \\
\hline $\begin{array}{l}\text { Vinha, Barreira, } \\
\text { Costa, Alves \& } \\
\text { Oliveira } \\
(2014) \\
\end{array}$ & Tomato & Ascorbic acid & $\begin{array}{l}\text { Tomato produced from organic systems was higher } \\
\text { in ascorbic acid }(+30 \%) \text { than those from } \\
\text { conventional systems. }\end{array}$ \\
\hline Baranski et al. (2014) & $\begin{array}{l}\text { Many organic and } \\
\text { conventional crops }\end{array}$ & $\begin{array}{l}\text { Vitamins }(\mathrm{B}, \mathrm{C}, \\
\mathrm{E})\end{array}$ & $\begin{array}{c}\text { Higher concentration of vitamin C was measured } \\
\text { in organic crops, while conventional crops were } \\
\text { higher in vitamin E. }\end{array}$ \\
\hline $\begin{array}{l}\text { Kazimierczak, } \\
\text { Hallmann \& } \\
\text { Rembiałkowska } \\
\text { (2015) } \\
\end{array}$ & $\begin{array}{l}\text { Rosemary, peppermint, } \\
\text { lemon balm, sage }\end{array}$ & Vitamin C & $\begin{array}{l}\text { Organic medicinal plants contained significantly } \\
\text { higher vitamin } C \text { than the conventional plants. }\end{array}$ \\
\hline $\begin{array}{l}\text { Khalil \& Hassan } \\
\text { (2015) }\end{array}$ & $\begin{array}{l}\text { Strawberries and } \\
\text { oranges }\end{array}$ & $\begin{array}{l}\text { Ascorbic acid, } \\
\beta \text {-carotene }\end{array}$ & $\begin{array}{l}\text { Organic strawberries had higher level of } \beta \text { - } \\
\text { carotene as well as ascorbic acid compared with } \\
\text { conventionally grown ones. Same for oranges. }\end{array}$ \\
\hline $\begin{array}{c}\text { Freedman \& } \\
\text { Mirabrishami (2015) } \\
\end{array}$ & Oranges & itamin $\mathrm{C}$ & $\begin{array}{c}\text { Vitamin C content was similar in juice from } \\
\text { organically and conventionally grown oranges. }\end{array}$ \\
\hline $\begin{array}{c}\text { Assumpção et al. } \\
(2015)\end{array}$ & Grape seed oils & Tocopherol & $\begin{array}{l}\text { No differences were found for grape seed oil } \\
\text { between conventional and organic products. }\end{array}$ \\
\hline Lee et al. (2016) & $\begin{array}{c}\text { Perilla leaves (Perilla } \\
\text { frutescens var. japonica } \\
\text { Hara) }\end{array}$ & $\begin{array}{l}\text { Vitamin } C, \\
\text { vitamin } E \text {, } \\
\beta \text {-carotene }\end{array}$ & $\begin{array}{l}\text { Organically grown perilla leaves had vitamin E } 49 \% \\
\text { greater than the conventional perilla leaves. Other } \\
\text { components were not showed the differences. }\end{array}$ \\
\hline $\begin{array}{l}\text { Kurubas, Maltas, } \\
\text { Dogan, Kaplan \& } \\
\text { Erkan (2018) } \\
\end{array}$ & Lettuce & Ascorbic acid & $\begin{array}{l}\text { The highest ascorbic acid content was obtained in } \\
\text { lettuce from the organic production system. }\end{array}$ \\
\hline $\begin{array}{l}\text { Ribes-Moya et al. } \\
(2018)\end{array}$ & Peppers & Ascorbic acid & $\begin{array}{l}\text { Organic peppers had higher content of ascorbic } \\
\text { acid than conventional ones. }\end{array}$ \\
\hline $\begin{array}{l}\text { Golubkina et al. } \\
\qquad(2018)\end{array}$ & Leek (Allium porrum) & Vitamin C & $\begin{array}{c}\text { Organic management resulted in higher vitamin C } \\
\text { in leek pseudo-stems compared to conventional } \\
\text { management. }\end{array}$ \\
\hline $\begin{array}{l}\text { Martí et al. } \\
\quad(2018)\end{array}$ & Tomato & L-ascorbic acid & $\begin{array}{c}\text { Organic farming increased L-ascorbic acid } \\
\text { contents, though this increase again was cultivar } \\
\text { and site depended. }\end{array}$ \\
\hline $\begin{array}{l}\text { Bender et al. } \\
\quad(2020)\end{array}$ & Carrot & Vitamin C & $\begin{array}{c}\text { Carrots managed organically had } 10.0 \% \text { higher } \\
\text { vitamin } \mathrm{C} \text { content than those managed } \\
\text { conventionally. }\end{array}$ \\
\hline $\begin{array}{l}\text { Barcanu-Tudor, } \\
\text { Vinatoru, Zamfir, } \\
\text { Bratu \& Draghici } \\
\text { (2020) }\end{array}$ & Bell peppers & $\beta$-carotene & $\begin{array}{l}\text { Higher levels of } \beta \text {-carotene and lycopene } \\
\text { registered in the organic bell peppers. }\end{array}$ \\
\hline
\end{tabular}




\begin{tabular}{|c|c|c|c|}
\hline Reference & Samples & $\begin{array}{c}\text { Compounds } \\
\text { analysed }\end{array}$ & Major conclusions \\
\hline $\begin{array}{c}\text { Kopczyńska et al. } \\
\text { (2020) }\end{array}$ & Cougette & $\begin{array}{l}\text { Chlorophylls, } \\
\text { carotenoids, } \\
\text { vitamin C }\end{array}$ & $\begin{array}{l}\text { Both chlorophylls content was significantly higher } \\
\text { in organic fruits vs conventional. The production } \\
\text { system significantly impacted the carotenoids } \\
\text { (sum), } \beta \text {-carotene and lutein content in plants and } \\
\text { had no effect on zeaxanthin. Higher concentrations } \\
\text { of carotenoids were found in organic compared to } \\
\text { the conventional courgette fruits, except for } \\
\text { zeaxanthin which was not affected by the } \\
\text { agronomic system. Content of L-ascorbic acid and } \\
\text { the vitamin C (sum of L-ASC and DHA) in } \\
\text { courgette fruits was not influenced by the } \\
\text { cultivation system. Content of DHA was found to } \\
\text { be higher in conventional fruits. }\end{array}$ \\
\hline $\begin{array}{l}\text { Hallmann \& Sabała } \\
\text { (2020) }\end{array}$ & $\begin{array}{l}\text { Ocimum basilicum } \mathrm{L} ., \\
\text { Allium ursinum } \mathrm{L} ., \\
\text { Origanum majorana } \mathrm{L} ., \\
\text { O. vulgare }\end{array}$ & $\beta$-carotene & $\begin{array}{l}\text { Conventional herbs contained significantly higher } \\
\text { concentrations of carotenoids, including beta- } \\
\text { carotene. }\end{array}$ \\
\hline
\end{tabular}

\section{MACRO- AND MICRO-ELEMENTS}

The results obtained in studies on differences in the contents of macro-and microelements between organically and conventionally grown vegetables, fruits and cereals differ very much. For instance, based on the meta-analysis, Heaton (2001) has summarised 400 papers dealing with comparisons of differences in chemical contents of food products produced organically and conventionally and has revealed that organic products had the higher contents of $\mathrm{Ca}, \mathrm{Mg}, \mathrm{Fe}$ and $\mathrm{Cr}$. Other authors, also applying the meta-analysis, submitted similar reports. Thus, according to Rembialkowska (2007), the contents of Fe and $\mathrm{Mg}$ in organically produced food products were higher by $21 \%$ and $29 \%$, respectively. Table 4 presents the comparative analysis of the contents of minerals between organic and conventional systems.

Worthington (1998) has summarised results presented in 34 publications in which organical and conventional food products were compared and have found that the contents of $\mathrm{Ca}, \mathrm{Mg}, \mathrm{Fe}$ and $\mathrm{Zn}$ were higher by $44.7 \%$, $37.8 \%, 42.9 \%$ and $25 \%$, respectively. In 2001, the same author summarised 41 papers, stating that organic food products contained the higher content of 21 elements ( $\mathrm{Fe}-21.1 \%$, $\mathrm{Mg}-29.3 \%, \mathrm{P}-13.6 \%, \mathrm{~B}, \mathrm{Ca}, \mathrm{Cr}, \mathrm{Cu}, \mathrm{J}, \mathrm{Mn}$, Mo, K, Se, Na, V, Zn). On the other hand, the contents of toxic heavy metals $\mathrm{Pb}, \mathrm{Cd}, \mathrm{Hg}$ and $\mathrm{Al}$ were lower. According to Worthington (2001), the majority of data related to the comparative mineral contents refer to lettuce, spinach, carrot, potato, and cabbage. As reported by the Agence Française de Sécurite Sanitaire des Aliments (AFSSA, 2003) the higher contents of $\mathrm{Fe}$ and $\mathrm{Mg}$ were detected in organically grown potatoes, carrots, red beets, lettuce, kale, leeks, beets, onions, celery and tomatoes. Organic carrots and potatoes were found to have higher contents of $\mathrm{K}$ and $\mathrm{Na}$ (Kumpulainen, 2001), and then of $\mathrm{P}$ and $\mathrm{Ca}$, while differences in contents of $\mathrm{Mg}$ and $\mathrm{K}$ were not recorded (Leclerc et al., 1991). A similar report has been submitted by Warman and Harvard (1998), who observed the differrences between organically and conventionally grown potatoes and sweet maize. On that occasion, they determined the higher contents of $\mathrm{P}$, $\mathrm{Mg}$ and $\mathrm{Na}$, and lower contents of $\mathrm{Mn}$ in tubers of organically grown potatoes whereas contents of $\mathrm{Mg}, \mathrm{B}$ and $\mathrm{Cu}$ were higher and contents of $\mathrm{B}$ andFe were lower in leaves of potatoes and sweet maize.

According to a report by Smith (1993), organic apples, pears, potatoes and wheat contained more mineral elements by $90 \%$ than conventional food products. Although there are numerous studies aimed at the determination of the existence of qualitative and quantitative differences in contents of nutrients between organically and conventionally grown cereals, the obtained results are still variable (Baranski et al., 2014). Worthington (2001) has stated that organically grown cereals contained significantly higher contents of $\mathrm{Fe}, \mathrm{Mn}$ and $\mathrm{P}$ compared to conventional cereals. According to Ciolek, Makarska, Wesolowski and Cierpiala (2012) the production method has no effect on the contents of microelements in barley, while seeds of organic wheat contained significantly 
increased contents of $\mathrm{Fe}, \mathrm{Zn}, \mathrm{Ca}$ and $\mathrm{Mg}$. In accordance with Ryan, Derrick and Dann (2004), higher amounts of $\mathrm{Mn}$ and $\mathrm{P}$ were found in conventionally grown wheat, while the amount of $\mathrm{Zn}$ and $\mathrm{Cu}$ were smaller. On the other hand, N, K, Mg, Ca, S and Fe showed small differences between organically and conventionally grown wheat. Contents of $\mathrm{Ca}$, $\mathrm{Cu}$ and $\mathrm{Zn}$ recorded in organically grown barely were higher than in conventionally grown barley (Alföldi et al., 1996). Biel, Gawęda, Jaroszewska and Hury (2018) reported increased $\mathrm{Mn}$ contents in organic soya bean, while contents of $\mathrm{P}, \mathrm{K}, \mathrm{Ca}, \mathrm{Mo}, \mathrm{Cu}$ and $\mathrm{Ni}$ were higher in conventional soya beans. The $\mathrm{Mg}$ content did not vary significantly.

Pedro et al. (2019) were among the first ones to perform a comparative analysis and characterise the differences between organic and conventional goji berries. Organic goji berries ensure the safety of factory-made food products, due to their lower content of heavy metals $(\mathrm{Cd}, \mathrm{Hg}$ and $\mathrm{Pb})$. Conventional berries contain $\mathrm{Hg}$ and $\mathrm{Pb}$ in more than the maximally acceptable tolerance limits by the Codex Alimentarius.

According to Wang et al. (2020), Mn, Zn, Cu and Mo were significantly higher in spelt wheat flour than in common wheat flour (31, 64,35 and $24 \%$ respectively), organic than conventional flour $(51,45,43$ and $70 \%$ respecttively) and whole-grain than white flour (216, 111, 49 and $43 \%$ respectively). $\mathrm{Fe}$ concentrations were also significantly higher in organic than conventional flour $(16 \%)$ and whole-grain than white flour $(63 \%)$. Furthermore, significant two-way interactions were established for $\mathrm{Mn}, \mathrm{Zn}$ and $\mathrm{Cu}$ between farming systems and flour type, with concentrations significantly higher in organic than conventional whole grain, but not white flour. The $\mathrm{Cu}$ concentration was significantly higher in organic than conventional common wheat flour, but not spelt wheat flour.

Mäder et al. (2007) have performed a 21-year trial and found no effect of organic and conventional farming systems in wheat related to the contents of $\mathrm{P}, \mathrm{K}, \mathrm{Zn}, \mathrm{Mo}$ and Co. The studies carried out on the contents of macroand microelements in grains of organically and conventionally grown maize, spelt wheat, soya bean and buckwheat, showed that organically grown maize was characterised by a higher content of zinc (Golijan, Kostić, Dojčinović \& Lekić, 2018a; Golijan, Kostić, Dojčinović\& Lekić, 2018b; Golijan et al., 2019a). Moreover, a higher Se content was determined in grains of organically grown maize, spelt wheat and soya bean compared to the grains of conventionally grown corresponding crops (Golijan, 2020a).

Some researchers indicated that conventionally grown plants and plant-based products contain higher concentrations of heavy metals, whereas other researchers stated the opposite. There is no clear difference in the content of heavy metals between organic and conventional crops (Rembiałkowska, 2007). Toxic heavy metals, such as $\mathrm{Cd}, \mathrm{Pb}, \mathrm{As}, \mathrm{Hg}$ etc., may be found in crops, which have very harmful effects on human health. They accumulate in foods and crops through industry, transport, municipal waste and agriculture. Cadmium, a highly toxic element (as well as $\mathrm{Pb}$ and $\mathrm{Hg}$ ), accumulates in the human body (especially in the liver and kidneys). Consequently, the intake of this element in the diet must be as small as possible. The European Commission has set maximum residue levels (MRL) in foods for Cd (European Commission, 2008). In conventional agricultural production, the soil and crops can be contaminated with $\mathrm{Cd}$ as a result of the application of phosphate fertilisers (Rembiałkowska, Załęcka, Badowski \& Ploeger, 2012). Golijan (2020a), studying the contents of macro-and microelements in organically and conventionnally grown maize, spelt wheat and soya bean pointed out the presence of potentially toxic elements, particularly $\mathrm{Cd}$ and $\mathrm{Sr}$, in grains of the crops. This study has shown that there was no regularity that would confirm which of the two methods of production - organic or conventional - would provide a better grain composition in terms of macro and microelements. Furthermore, similar results were presented in another two papers published by Golijan et al. (2017b; 2019b), in which the authors reported that some toxic elements, such as $\mathrm{Al}, \mathrm{Sr}, \mathrm{Cd}, \mathrm{As}$ and $\mathrm{Pb}$, could be found in grains of organically and conventionally produced maize, spelt wheat, soya bean and buckwheat.

Although a number of researchers found that organically grown vegetables contain elevated level of minerals, some believe that differences do not exist (Clarke \& Merrow, 1979; Lairon 
et al., 1984, Lairon et al., 1986; Termine et al., 1987; Perez-Llamas, Navarro, Marin, Madrid \& Zamora, 1996; Warman \& Havard, 1996; Tan, Wang \& Lee, 1998; Fjelkner-Modig et al., 2000). This statement also refers to differences between organically and conventionally grown fruits (Alvarez et al., 1993; DeEll \& Prange, 1993; Bourn, 1994; Woëse et al., 1997; Alvarez, Ortega, Fernandez \& Borges, 2001; Bourn \& Prescott, 2002), which is in agreement with the AFSSA report (2003).

There is a difference in soil fertility maintenance in organic and conventional agricultural production, which further affects the soil dynamics and plant metabolism, due to which plants have different nutritive compositions. Mineral fertilisers, mainly consisting from nitrogen, phosphorus and potassium, do not improve the soil structure and do not stimulate the activities of microorganisms. On the other hand, good organic production practice requires the use of organic fertilisers, presservation of the soil structure, the increase of the community of microorganisms, due to which nutritive substances are gradually released during the long period, and the soil is more fertile. The abundance of microorganisms in organic soils contributes to the formation of specific compounds (such as citrates and lactates), which combine with soil minerals making them easily available for absorption via plant roots. This is one of the facts that explains the existence of a trend of the higher contents of macro-and microelements in organic crops (Worthington, 2001). It is obvious that fertilisers with easily available phosphors are used in conventional farming, which increases the intake of phosphorus in all parts of the plant. On the other hand, it disrupts mycorrhiza, which results in the reduced $\mathrm{Zn}$ uptake, but also in the increased Mn uptake (Mäder et al., 2007). Potassium fertilisers reduce the content of $\mathrm{Mg}$ in plants (and then of $\mathrm{P}$ - indirectly, because the absorption of $\mathrm{P}$ depends on $\mathrm{Mg}$, so the plant will have less $\mathrm{P}$ ), due to which plants absorb less $\mathrm{Mg}$ from the soil. Potassium fertilisers are differently added to plants in organic and conventional production. Conventional potassium fertilisers are easily dissolved in the soil, due to which conventionally grown plants have a higher $\mathrm{K}$ content. The soil, used in organic farming, contains moderate amounts of $\mathrm{K}$ and $\mathrm{Mg}$, due to which it is expected that plants contain higher amounts of $\mathrm{Mg}$ and $\mathrm{P}$ in comparison to plants conventionally grown (Worthington, 2001).

Table 4.

Comparative analysis of mineral content in plants/food grown in organic and conventional systems

\begin{tabular}{|c|c|c|c|}
\hline Reference & Samples & $\begin{array}{c}\text { Compounds } \\
\text { analysed }\end{array}$ & Major conclusions \\
\hline $\begin{array}{l}\text { Worthington } \\
\text { (2001) }\end{array}$ & $\begin{array}{l}\text { Many organic and } \\
\text { conventional crops }\end{array}$ & $\begin{array}{l}\mathrm{Ca}, \mathrm{Mg}, \mathrm{K}, \mathrm{Na} \\
\quad \mathrm{P}, \mathrm{Fe}, \mathrm{Cu}\end{array}$ & $\begin{array}{l}\text { Organically grown cereals contained significantly } \\
\text { higher contents of } \mathrm{Fe}, \mathrm{Mn} \text { and } \mathrm{P} \text { compared to } \\
\text { conventional cereals. }\end{array}$ \\
\hline $\begin{array}{l}\text { Kumpulainen } \\
\text { (2001) }\end{array}$ & Carrots, potatoes & $\mathrm{K}, \mathrm{Na}$ & $\begin{array}{l}\text { Organic carrots and potatoes were found to have } \\
\text { higher contents of } \mathrm{K} \text { and Na. }\end{array}$ \\
\hline $\begin{array}{l}\text { Ryan et al. } \\
\quad(2004)\end{array}$ & Wheat & $\begin{array}{l}\text { N, P, K, Mg, } \\
\mathrm{Mn}, \mathrm{Ca}, \mathrm{S}, \mathrm{Fe}\end{array}$ & $\begin{array}{c}\mathrm{N}, \mathrm{K}, \mathrm{Mg}, \mathrm{Ca}, \mathrm{S} \text { and } \mathrm{Fe} \text { showed small differences } \\
\text { between organically and conventionally grown } \\
\text { wheat. Organic wheat displayed higher levels of } \\
\text { copper and zinc and lower levels of } \mathrm{P} \text { and } \mathrm{Mn} \\
\text { compared with conventional grown. }\end{array}$ \\
\hline $\begin{array}{l}\text { Lombardi-Boccia et } \\
\text { al. (2004) }\end{array}$ & Plums & $\begin{array}{l}\mathrm{P}, \mathrm{K}, \mathrm{Ca}, \mathrm{Mg} \\
\mathrm{Zn}, \mathrm{Na}, \mathrm{Fe}, \mathrm{Cu}\end{array}$ & $\begin{array}{l}\text { The organic plums showed higher } \mathrm{P}, \mathrm{K}, \mathrm{Ca}, \mathrm{Mg} \text {, } \\
\mathrm{Zn} \text { content and lower } \mathrm{Na}, \mathrm{Fe}, \mathrm{Cu} \text { content compared } \\
\text { with the conventionally plums. }\end{array}$ \\
\hline $\begin{array}{l}\text { Harcz et al. } \\
\text { (2007) }\end{array}$ & Winter wheat & $\mathrm{Hg}, \mathrm{Cd}, \mathrm{Pb}$ & $\begin{array}{l}\text { The concentrations of } \mathrm{Cd} \text { and } \mathrm{Hg} \text { showed no } \\
\text { significant difference, but lead content were higher } \\
\text { in organic cereals compared with conventional. }\end{array}$ \\
\hline $\begin{array}{l}\text { Liu et al. } \\
\text { (2007) }\end{array}$ & $\begin{array}{l}\text { Conventional, organic } \\
\text { and sustainable farms }\end{array}$ & $\begin{array}{l}\mathrm{Ca}, \mathrm{Mg}, \mathrm{Na} \\
\mathrm{Mn}, \mathrm{Zn}, \mathrm{Cu}, \mathrm{P} \\
\mathrm{K}\end{array}$ & $\begin{array}{c}\mathrm{Ca}, \mathrm{Mg}, \mathrm{Mn}, \mathrm{P}, \mathrm{Zn} \text {, and } \mathrm{Cu} \text { were greater in soils } \\
\text { under organic production. }\end{array}$ \\
\hline $\begin{array}{l}\text { Mäder et al. } \\
\text { (2007) }\end{array}$ & Wheat & $\begin{array}{c}\mathrm{P}, \mathrm{K}, \mathrm{Ca}, \mathrm{Mg} \\
\mathrm{Mn}, \mathrm{Zn}, \mathrm{Cu} \\
\mathrm{Mo}, \mathrm{Co} \\
\end{array}$ & $\begin{array}{l}\text { No effect of organically and conventionally grown } \\
\text { wheat on the contents of P, K, Zn, Mo and Co. }\end{array}$ \\
\hline $\begin{array}{l}\text { Dangour et al. } \\
\text { (2009) }\end{array}$ & $\begin{array}{l}\text { Many organic and } \\
\text { conventional crops }\end{array}$ & $\begin{array}{l}\mathrm{Mg}, \mathrm{Ca}, \mathrm{P}, \mathrm{K} \\
\mathrm{Zn}, \mathrm{Cu}\end{array}$ & $\begin{array}{l}\text { Organically produced crops were higher in } \\
\text { phosphorus than conventional samples. }\end{array}$ \\
\hline
\end{tabular}




\begin{tabular}{|c|c|c|c|}
\hline Reference & Samples & $\begin{array}{c}\begin{array}{c}\text { Compounds } \\
\text { analysed }\end{array} \\
\end{array}$ & Major conclusions \\
\hline $\begin{array}{l}\text { Hoefkens et al. } \\
\qquad(2009)\end{array}$ & $\begin{array}{l}\text { Potatoes, carrot, tomato, } \\
\text { and lettuce }\end{array}$ & $\mathrm{Cd}, \mathrm{Pb}$ & $\begin{array}{l}\text { No significant variation for the heavy elements } \mathrm{Cd} \\
\text { and } \mathrm{Pb} \text { between conventional and organic potatoes. }\end{array}$ \\
\hline $\begin{array}{l}\text { Roussos \& } \\
\text { Gasparatos } \\
\quad(2009)\end{array}$ & Apple & $\begin{array}{l}\mathrm{K}, \mathrm{Ca}, \mathrm{Mg}, \mathrm{Na} \\
\mathrm{Mn}, \mathrm{Fe}, \mathrm{Cu}, \mathrm{B}, \\
\quad \mathrm{Zn}\end{array}$ & $\begin{array}{c}\text { Organic apple showed higher } \mathrm{K}, \mathrm{Ca}, \mathrm{Mg}, \mathrm{Na}, \mathrm{Mn} \\
\text { content than the conventionally grown ones, while } \\
\text { conventionally grown apple showed more } \mathrm{Fe}, \mathrm{Cu} \text {, } \\
\mathrm{B}, \mathrm{Zn} \text {. }\end{array}$ \\
\hline $\begin{array}{l}\text { Reganold et al. } \\
\text { (2010) }\end{array}$ & Strawberry & $\begin{array}{l}\mathrm{N}, \mathrm{P}, \mathrm{K}, \mathrm{Ca} \\
\mathrm{Mg}, \mathrm{B}, \mathrm{Zn}, \mathrm{S} \\
\mathrm{Mn}, \mathrm{Cu}, \mathrm{Fe}\end{array}$ & $\begin{array}{l}\text { Leaf } \mathrm{P} \text { and fruit } \mathrm{P} \text { and } \mathrm{K} \text { concentrations were } \\
\text { significantly higher in conventionally grown } \\
\text { strawberry plants than in organically grown plants; } \\
\text { leaf } \mathrm{Mg} \text { and fruit } \mathrm{N} \text { were also notably higher in } \\
\text { conventionally grown strawberry plants. All other } \\
\text { strawberry and leaf nutrient concentrations were } \\
\text { similar. }\end{array}$ \\
\hline $\begin{array}{l}\text { Laursen et al. } \\
\qquad(2011)\end{array}$ & $\begin{array}{l}\text { Wheat, barley, faba } \\
\text { bean, potato }\end{array}$ & $\begin{array}{l}\mathrm{K}, \mathrm{Mg}, \mathrm{P}, \mathrm{S}, \mathrm{Ca} \\
\mathrm{Fe}, \mathrm{Mn}, \mathrm{B}, \mathrm{Zn} \\
\mathrm{Cu}, \mathrm{Mb}, \mathrm{Sr}, \mathrm{Na}\end{array}$ & No differences in mineral levels. \\
\hline $\begin{array}{l}\text { Vrček \& Vinković } \\
\text { Vrček } \\
(2012)\end{array}$ & Wheat flour & $\begin{array}{l}\mathrm{Al}, \mathrm{As}, \mathrm{Cd}, \mathrm{Cr} \\
\mathrm{Pb}, \mathrm{Fe}, \mathrm{Mg}, \mathrm{Mo} \\
\mathrm{Ni}, \mathrm{V}\end{array}$ & $\begin{array}{l}\text { The significant differences among conventional vs. } \\
\text { organic wheat flours were obtained for } \mathrm{As}, \mathrm{Cd}, \mathrm{Cr} \text {, } \\
\mathrm{Fe}, \mathrm{Mg}, \mathrm{Mo}, \mathrm{Ni} \text { and } \mathrm{V} \text {. Toxic metals (Al, } \mathrm{As}, \mathrm{Cd} \\
\text { and } \mathrm{Pb} \text { ) input was higher in conventional } \\
\text { compared with organic wheat flours. }\end{array}$ \\
\hline $\begin{array}{l}\text { Ciolek et al. } \\
\text { (2012) }\end{array}$ & $\begin{array}{l}\text { Wheat, hulled and } \\
\text { naked barley, oat }\end{array}$ & $\begin{array}{l}\mathrm{Ca}, \mathrm{K}, \mathrm{Mg}, \mathrm{Cu} \\
\mathrm{Mn}, \mathrm{Fe}, \mathrm{Zn}\end{array}$ & $\begin{array}{l}\text { Organic wheat grain was characterized by a higher } \\
\text { content of } \mathrm{Mn}, \mathrm{Fe}, \mathrm{Zn}, \mathrm{Ca} \text { and } \mathrm{Mg} \text { compared to } \\
\text { conventional grain. Lower content of Fe and } \mathrm{Zn} \\
\text { was determined in organic barley and oat. }\end{array}$ \\
\hline $\begin{array}{l}\text { Gąstoł \& Domagała- } \\
\text { Swiątkiewicz } \\
\text { (2013) }\end{array}$ & $\begin{array}{l}\text { Fruit and vegetable } \\
\text { fields producing organic } \\
\text { and conventional crops }\end{array}$ & $\begin{array}{l}\mathrm{Cu}, \mathrm{B}, \mathrm{Fe}, \mathrm{Mn} \\
\mathrm{Zn}, \mathrm{Ni}, \mathrm{Pb}, \mathrm{Cd} \\
\mathrm{Ca}, \mathrm{P}, \mathrm{Mg}, \mathrm{S} \\
\mathrm{Na}\end{array}$ & $\begin{array}{l}\text { Higher amounts of all elements in organic } \\
\text { produced crop. }\end{array}$ \\
\hline $\begin{array}{l}\text { Ilić et al. } \\
\text { (2014) }\end{array}$ & Tomato & $\begin{array}{l}\mathrm{Pb}, \mathrm{Cu}, \mathrm{Cr} \\
\mathrm{Co}, \mathrm{Cd}\end{array}$ & $\begin{array}{c}\text { Significantly higher amounts of } \mathrm{Pb}, \mathrm{Zn}, \mathrm{Cu} \text {, and } \mathrm{Ni} \\
\text { were found in conventional tomatoes. The } \\
\text { contaminants levels were lower than the maximum } \\
\text { limits. }\end{array}$ \\
\hline $\begin{array}{l}\text { de Souza Araújo et } \\
\text { al. } \\
\text { (2014) }\end{array}$ & $\begin{array}{l}\text { Lettuce, peppers, } \\
\text { tomatoes }\end{array}$ & $\begin{array}{c}\mathrm{Cd}, \mathrm{Ni}, \mathrm{Pb}, \mathrm{Cr}, \\
\mathrm{Cu}, \mathrm{Fe}, \mathrm{K}, \mathrm{Mg}, \\
\mathrm{Mn}, \mathrm{Zn}, \mathrm{Na}\end{array}$ & $\begin{array}{c}\mathrm{Pb} \text { and } \mathrm{Cd} \text { contents displayed no significant } \\
\text { difference between conventional and organic lettuces. } \\
\text { Organic lettuces contained significantly higher } \\
\text { amount of Ni compared to the conventional lettuces. } \\
\text { Twice as much as nickel was detected in conventional } \\
\text { peppers compared to organic ones. Organic lettuce } \\
\text { had significantly higher levels of } \mathrm{Cr}, \mathrm{Cu}, \mathrm{Fe}, \mathrm{K} \text { and } \\
\mathrm{Mg} \text {, whereas conventional samples had higher levels } \\
\text { of } \mathrm{Mn} \text { and } \mathrm{Zn} \text {. The organic peppers showed higher } \\
\text { mineral levels (Cr, } \mathrm{K}, \mathrm{Mg}, \mathrm{Na} \text {, and } \mathrm{Zn} \text { ) when } \\
\text { compared to the conventional samples. Organic and } \\
\text { conventional tomatoes exhibited high levels of } \mathrm{Mn} \text {, } \\
\mathrm{Fe}, \mathrm{Cu} \text { and } \mathrm{Cr} \text {. }\end{array}$ \\
\hline
\end{tabular}

\begin{tabular}{|c|c|c|c|}
\hline $\begin{array}{l}\text { Vinković Vrček et al. } \\
\text { (2014) }\end{array}$ & Wheat flour & $\begin{array}{l}\mathrm{K}, \mathrm{Mg}, \mathrm{Ca}, \mathrm{Fe}, \\
\mathrm{Mn}, \mathrm{Zn}, \mathrm{Al}, \mathrm{Mo}, \\
\mathrm{Ni}, \mathrm{Cr}, \mathrm{Cd}, \mathrm{Pb}, \\
\mathrm{Se}, \mathrm{V}, \mathrm{Co}, \mathrm{Cu}, \\
\quad \mathrm{Sr}, \mathrm{As}\end{array}$ & $\begin{array}{l}\text { Organic wheat flour had more } \mathrm{K}, \mathrm{Mg}, \mathrm{Zn}, \mathrm{Ni}, \mathrm{Mo} \\
\text { than conventional. }\end{array}$ \\
\hline $\begin{array}{l}\text { Bøhn et al. } \\
\text { (2014) }\end{array}$ & Soybeans & $\begin{array}{l}\mathrm{Ba}, \mathrm{Cu}, \mathrm{Fe}, \mathrm{Mn}, \\
\mathrm{Mo}, \mathrm{Se}, \mathrm{Zn}\end{array}$ & $\begin{array}{l}\text { The content of } \mathrm{Zn} \text { was significantly higher in } \\
\text { organic samples compared to the conventional and } \\
\text { organic samples. Other differences were relatively } \\
\text { small. }\end{array}$ \\
\hline $\begin{array}{l}\text { Zhang, Jiao, Li \& Lei } \\
\text { (2014) }\end{array}$ & Black sesame & $\begin{array}{l}\mathrm{K}, \mathrm{Mg}, \mathrm{Ca}, \mathrm{Na} \\
\mathrm{P}, \mathrm{Cu}, \mathrm{Fe}, \mathrm{Cr} \\
\mathrm{Si}, \mathrm{Sr}, \mathrm{Al}, \mathrm{Ba} \\
\mathrm{Ti}\end{array}$ & $\begin{array}{c}\text { Organic black sesame had } 58 \%-132 \% \text { richer } \\
\text { content of } \mathrm{K}, \mathrm{Mg}, \mathrm{Ca}, \mathrm{Na}, \mathrm{P} \text {, and } 21 \%-554 \% \\
\text { richer contents of } \mathrm{Cu}, \mathrm{Fe}, \mathrm{Cr}, \mathrm{Zn}, \mathrm{Si}, \mathrm{Sr} \text { as well as } \\
\text { richer } \mathrm{Al}(40 \%), \mathrm{Ba},(485), \mathrm{Ti}(566 \%) \text { than the } \\
\text { conventional. }\end{array}$ \\
\hline
\end{tabular}




\begin{tabular}{|c|c|c|c|}
\hline Reference & Samples & $\begin{array}{c}\begin{array}{c}\text { Compounds } \\
\text { analysed }\end{array} \\
\end{array}$ & Major conclusions \\
\hline $\begin{array}{c}\text { Uckoo, Jayaprakasha } \\
\text { \& Patil } \\
\text { (2015) }\end{array}$ & Lemons & $\begin{array}{c}\mathrm{P}, \mathrm{K}, \mathrm{Ca}, \mathrm{Mg}, \\
\quad \mathrm{Na}, \mathrm{Zn}, \mathrm{Fe}\end{array}$ & $\begin{array}{l}\text { Organic lemons showed the highest } \mathrm{P} \text { content, } \\
\text { whereas the conventionally grown showed the } \\
\text { lowest. Conventional lemons showed higher } \mathrm{K} \text {, } \\
\mathrm{Ca}, \mathrm{Mg}, \mathrm{Na}, \mathrm{Zn}, \mathrm{Fe} \text { levels compared with the } \\
\text { organic. }\end{array}$ \\
\hline $\begin{array}{l}\text { Suja et al. } \\
\text { (2017) }\end{array}$ & $\begin{array}{c}\text { Taro (Colocasia } \\
\text { esculenta) }\end{array}$ & $\begin{array}{l}\mathrm{pH}, \mathrm{P}, \mathrm{K}, \mathrm{Ca}, \\
\mathrm{Mg}, \mathrm{Fe}, \mathrm{Mn}, \mathrm{Zn}, \\
\mathrm{Cu}, \text { organic } \mathrm{C}, \\
\text { ash }\end{array}$ & $\begin{array}{c}\text { Cormel quality was better under organic } \\
\text { management, with higher } \mathrm{P}, \mathrm{K}, \mathrm{Ca} \text { and } \mathrm{Mg} \\
\text { contents. Organic plots showed significantly } \\
\text { higher } \mathrm{pH}(+1.2 \text { unit) and available } \mathrm{P} \text { and higher } \\
\text { soil organic } \mathrm{C}(+39 \%) \text {, exchangeable } \mathrm{Ca}, \mathrm{Mg}, \mathrm{Fe} \text {, } \\
\mathrm{Mn}, \mathrm{Zn} \text { and } \mathrm{Cu} \text { status. Conventionally produced } \\
\text { taro had higher ash content than taro from organic } \\
\text { systems }(20.07 \%) \text {. }\end{array}$ \\
\hline
\end{tabular}

\begin{tabular}{|c|c|c|c|}
\hline $\begin{array}{c}\text { Dos Santos et al. } \\
\text { (2017) }\end{array}$ & $\begin{array}{c}\text { Sweet potato, carrot, } \\
\text { okra, cabbage, eggplant } \\
\text { brinjal }\end{array}$ & $\begin{array}{c}\mathrm{Ca}, \mathrm{Cu}, \mathrm{Fe}, \\
\mathrm{K}, \mathrm{Mg}, \mathrm{Mn}, \mathrm{P} \\
\mathrm{Na} \\
\end{array}$ & $\begin{array}{c}\text { Samples of organic cultivars showed higher } \\
\text { concentrations of minerals, such as } \mathrm{Ca}, \mathrm{Cu}, \mathrm{Fe}, \mathrm{K} \text {, } \\
\mathrm{Mg}, \mathrm{Mn} \text { and } \mathrm{P} \text {. }\end{array}$ \\
\hline $\begin{array}{c}\text { Kapoulas et al. } \\
\text { (2017) }\end{array}$ & Lettuce, onion & $\begin{array}{l}\mathrm{N}, \mathrm{P}, \mathrm{K}, \mathrm{Ca} \\
\mathrm{Mg}, \mathrm{B}, \mathrm{Mn}, \mathrm{Zn}, \\
\quad \mathrm{Fe}, \mathrm{Cu}\end{array}$ & $\begin{array}{l}\text { Organically grown green onions had higher } \\
\text { contents of all macro and microelements (except } \\
\mathrm{Cu} \text { ) compared to the conventionally grown onions. } \\
\text { Lettuce from convential systems contained more } \\
\mathrm{Ca}, \mathrm{Mg}, \mathrm{Mn}, \mathrm{Fe}, \mathrm{Cu} \text { than that from organic } \\
\text { production. }\end{array}$ \\
\hline $\begin{array}{l}\text { Yu, Guo, Jiang, Song } \\
\text { \& Muminov } \\
\text { (2018) }\end{array}$ & Corn grain & $\begin{array}{l}\mathrm{P}, \mathrm{K}, \mathrm{Mg}, \mathrm{Fe} \\
\mathrm{Zn}, \mathrm{S}, \mathrm{Mn}\end{array}$ & $\begin{array}{l}\text { The organic corn grains were rich in } \mathrm{K}(30 \%), \mathrm{P} \\
(30 \%), \mathrm{Mg}(20 \%) \text { and } \mathrm{Fe} \text { and } \mathrm{Zn} \text {, although the } \\
\text { differences were not significant. Conventional corn } \\
\text { grain exhibited high S (15\%) and } \mathrm{Mn}(17 \%) \\
\text { content. }\end{array}$ \\
\hline $\begin{array}{l}\text { Biel et al. } \\
\text { (2018) }\end{array}$ & Soybean & $\begin{array}{l}\mathrm{P}, \mathrm{K}, \mathrm{Mg}, \mathrm{Ca} \\
\mathrm{Mo}, \mathrm{Mn}, \mathrm{Cu}, \mathrm{Ni}\end{array}$ & $\begin{array}{l}\text { The contents of } \mathrm{P}, \mathrm{K}, \mathrm{Ca}, \mathrm{Cu} \text { and } \mathrm{Ni} \text { were found to } \\
\text { be significantly higher in conventional soybean } \\
\text { seeds. }\end{array}$ \\
\hline $\begin{array}{l}\text { Golubkina et al. } \\
\qquad(2018)\end{array}$ & Leek (Allium porrum) & $\begin{array}{l}\mathrm{Al}, \mathrm{As}, \mathrm{B}, \mathrm{Ca}, \\
\mathrm{Cd}, \mathrm{Co}, \mathrm{Cr}, \mathrm{Cu} \text {, } \\
\mathrm{Fe}, \mathrm{Hg}, \mathrm{I}, \mathrm{K}, \mathrm{Li}, \\
\mathrm{Mg}, \mathrm{Mn}, \mathrm{Na} \\
\mathrm{Ni}, \mathrm{P}, \mathrm{Pb}, \mathrm{Si} \\
\mathrm{Sn}, \mathrm{Sr}, \mathrm{V}, \mathrm{Zn}\end{array}$ & $\begin{array}{c}\text { Among the mineral elements, only } \mathrm{K} \text { was } \\
\text { significantly affected by the management system, } \\
\text { showing a higher content in organically grown } \\
\text { pseudo-stems. }\end{array}$ \\
\hline $\begin{array}{c}\text { Golijan et al. } \\
\text { (2017b) }\end{array}$ & $\begin{array}{l}\text { Maize, wheat, spelt, } \\
\text { soybean, buckwheat }\end{array}$ & $\mathrm{Ca}, \mathrm{Mg}, \mathrm{P}$ & $\begin{array}{c}\text { The content of } \mathrm{Ca}, \mathrm{Mg} \text { and } \mathrm{P} \text { differs between } \\
\text { maize, spelt, soybean and buckwheat in different } \\
\text { years of production and in both production } \\
\text { systems, as well. }\end{array}$ \\
\hline $\begin{array}{c}\text { Golijan et al. } \\
\text { (2018a) }\end{array}$ & $\begin{array}{l}\text { Maize, spelt, } \\
\text { buckwheat, soybean }\end{array}$ & $\mathrm{Fe}, \mathrm{Zn}$ & $\begin{array}{l}\text { The highest } \mathrm{Zn} \text { concentration was detected in } \\
\text { organic }(19.92 \mu \mathrm{g} / \mathrm{g}) \text { and conventionally }(25.05 \\
\mu \mathrm{g} / \mathrm{g}) \text { produced soybean seed from } 2016 \text {. The } \\
\text { highest Fe content was found in the seed of } \\
\text { organic }(122.55 \mu \mathrm{g} / \mathrm{g}) \text { and conventionally }(94.33 \\
\mu \mathrm{g} / \mathrm{g}) \text { grown buckwheat seed from } 2016 \text {. }\end{array}$ \\
\hline $\begin{array}{l}\text { Golijan et al. } \\
(2018 b)\end{array}$ & Spelt seed & $\mathrm{Fe}, \mathrm{Zn}$ & $\begin{array}{l}\text { Quantity of } \mathrm{Fe} \text { and } \mathrm{Zn} \text { was higher in } \\
\text { conventionally grown spelt seed compared to } \\
\text { organically grown seed. }\end{array}$ \\
\hline $\begin{array}{c}\text { Dutra, Rodrigues, de } \\
\text { Oliveira, Pereira \& } \\
\text { Lima } \\
(2018)\end{array}$ & Grape juices and wines & $\mathrm{Cu}, \mathrm{Fe}, \mathrm{Mn}$ & $\begin{array}{l}\text { No significant differences were observed on } \mathrm{Cu} \text {, } \\
\qquad \mathrm{Fe} \text { and } \mathrm{Mn} \text { minerals. }\end{array}$ \\
\hline $\begin{array}{l}\text { Pedro et al. } \\
\text { (2019) }\end{array}$ & Goji berry & $\begin{array}{l}\mathrm{K}, \mathrm{Na}, \mathrm{P}, \mathrm{Ca}, \\
\mathrm{Mg}, \mathrm{Fe}, \mathrm{Zn}, \mathrm{Cu}, \\
\mathrm{Mn}, \mathrm{Cd}, \mathrm{Hg}, \mathrm{Pb}\end{array}$ & $\begin{array}{c}\text { Organic fruits exhibited significantly higher levels } \\
\text { of } \mathrm{K}, \mathrm{Na}, \mathrm{Ca}, \mathrm{Fe}, \mathrm{Zn} \text { and } \mathrm{Cu} \text { elements than } \\
\text { conventional goji. Organic goji berry showed } \\
\text { concentrations of the toxic elements } \mathrm{Cd}, \mathrm{Hg} \text { and } \\
\mathrm{Pb} \text { within the limits established by the Codex } \\
\text { Alimentarius, while conventional fruits had levels } \\
\text { of } \mathrm{Hg} \text { and } \mathrm{Pb} \text { above the established maximum } \\
\text { levels. }\end{array}$ \\
\hline
\end{tabular}




\begin{tabular}{|c|c|c|c|}
\hline Reference & Samples & $\begin{array}{c}\begin{array}{c}\text { Compounds } \\
\text { analysed }\end{array} \\
\end{array}$ & Major conclusions \\
\hline $\begin{array}{l}\text { Golijan et al. } \\
\qquad(2019 a)\end{array}$ & Buckwheat & $\begin{array}{l}\mathrm{B}, \mathrm{Cu}, \mathrm{Fe}, \mathrm{Mn} \\
\mathrm{Mo}, \mathrm{Zn}\end{array}$ & $\begin{array}{l}\text { In conventional buckwheat grains, higher quantity } \\
\text { of } \mathrm{B}, \mathrm{Cu} \text { and } \mathrm{Zn} \text { was determined, while organic } \\
\text { buckwheat seed contained higher content of Fe and } \\
\text { Mn compared to conventionally grown sample. }\end{array}$ \\
\hline $\begin{array}{l}\text { Golijan et al. } \\
\qquad(2019 b)\end{array}$ & Maize & $\mathrm{Cd}, \mathrm{Cr}, \mathrm{Ni}, \mathrm{Pb}$ & $\begin{array}{l}\text { Conventional maize contained higher amount of } \mathrm{Cr} \\
\text { and } \mathrm{Pb} \text {, while content of } \mathrm{Ni} \text { and } \mathrm{Cd} \text { was higher in } \\
\text { the organic seed. }\end{array}$ \\
\hline $\begin{array}{l}\text { Kwiatkowski } \\
\text { \&Harasim } \\
(2020) \\
\end{array}$ & $\begin{array}{l}\text { Crop rotations:potato- } \\
\text { winter wheat-field } \\
\text { bean-spring barley } \\
\end{array}$ & $\begin{array}{l}\mathrm{P}, \mathrm{K}, \mathrm{Mg}, \mathrm{B} \\
\mathrm{Cu}, \mathrm{Mn}, \mathrm{Zn}\end{array}$ & $\begin{array}{l}\text { Organic system contributed to an increased soil } \\
\text { content of magnesium, boron, copper, manganese, } \\
\text { zinc, organic carbon, and total nitrogen. }\end{array}$ \\
\hline $\begin{array}{l}\text { Wang et al. } \\
\quad(2020)\end{array}$ & $\begin{array}{l}\text { Triticum aestivum vs } T \text {. } \\
\text { spelta, flour type } \\
\text { (wholegrain vs white) }\end{array}$ & $\begin{array}{l}\mathrm{P}, \mathrm{K}, \mathrm{Mg}, \mathrm{Mn} \\
\mathrm{Zn}, \mathrm{Cu}, \mathrm{Al}, \mathrm{Na} \\
\quad \mathrm{Ca}, \mathrm{S}, \mathrm{Mo}\end{array}$ & $\begin{array}{l}\text { Organic flour had higher levels minerals (Al (12\%) } \\
\text { and } \mathrm{Ni}(81 \%) \text { ) content than conventional flour. } \\
\text { Spelt wheat had higher mineral levels than } \\
\text { common wheat, as well as } 28 \% \text { higher Cd content. }\end{array}$ \\
\hline
\end{tabular}

\section{SECONDARY METABOLITES}

Plants contain a large number of organic compounds, traditionally classified as primary and secondary metabolites. The latter are compounds that have no direct role in fundamental metabolic processes but have an important ecological significance for the survival of plants, as well as a protective role in the adaptation of plants to conditions of abiotic and biotic stress. A variety, plant maturity, light, temperature and a number of factors affect the number of secondary metabolites in the plant (Lairon, 2010).

Phenolic compounds represent the largest group of secondary metabolites and encompass simple compounds such as phenolic acids, as well as polymers of high molecular weight, such as condensed tannins (Šarčević-Todosijević et al., 2019). Polyphenols are found in plants in two forms - free and bound polyphenols. In fruits and vegetables, the bound polyphenols make up to $24 \%$ of total polyphenol content, while the majority of polyphenols in cereals are found in the bound form (Acosta-Estrada, Gutiérrez-Uribe \& Serna-Saldívar, 2014).

Polyphenols in plants may range from several grammes per kilogrammes, whereby the concentration is higher in the skin/peel and the coat than in the fruit (Benbrook, 2005). Polyphenols exhibit antioxidant activity, antiviral, antibacterial, hypoglycaemic, anticancer, antiarthritic as well as anti-inflammatory activities, and are used in the treatment and prevention of chronic diseases (Owen et al., 2000).

There are many studies related to the comparison of contents of polyphenols and other antioxidants between organically and conventionally grown plants and plant-based products. The comparative analysis of secondary metabolites, organic acids and antioxidant activity between organic and conventional systems is presented in table 5 .

A larger number of data are available for vegetables and fruits, and a slightly smaller number for cereals. Numerous studies state that organically produced food products are richer in the content of organic acids and polyphenolic compounds with antioxidant properties. However, Dangour et al. (2009) reported that organic and conventional production systems did not significantly affect nutritive differences and the content of polyphenols in food products.

The results of testing the content of polyphenols and the antioxidant activity in organic and conventional leek point out that the cultivation method did not significantly affect the polyphenol concentration (Golubkina et al., 2018). Similar results were reported by Brazinskiene et al. (2014) for potato, Valverde et al. (2015) for broccoli, Lee et al. (2016) for Perilla leaves, Kapoulas et al. (2017) for lettuce and onion, Dutra et al. (2018) for grape juices and wines.

According to Benbrook, Zhao, Yáñez, Davies and Andrews (2008), organically produced food products in comparison with conventional ones have an antioxidant capacity higher by $88 \%$, as well as amounts of total polyphenols, quercetin and kaempferol higher by $72 \%, 87 \%$ and $55 \%$, respectively. As reported by Rembialkowska (2007), organically produced foods have twice the amount of polyphenols compared to conventional ones. According to 
Benbrook (2005), organic products have an antioxidant capacity higher by approximately $30 \%$ than conventional ones.

Baranski et al. (2014) performed the metaanalysis of 342 publications related to differences between conventionally and organically grown crops regarding the contents of numerous secondary metabolites, as well as macroand micro-nutrients and have reported that organically grown plants contained signifycantly higher amounts of antioxidants, prima- rily polyphenols, such as flavanones, flavones, flavonols, stilbenes and anthocyanins. It should be emphasised that the observed differences were more credible because the data were gained on the same crops cultivated in numerous trials performed in many growing seasons on the same areas under various climatic and weather conditions.

According to Levite, Adrian and Tamm (2000), organic wine contains a higher amount of resveratrol.

Table 5.

Comparative analysis of secondary metabolites, organic acids and antioxidant activity in plants/food from organic and conventional systems

\begin{tabular}{cccc}
\hline Reference & Samples & Compounds analysed & Major conclusions \\
\hline $\begin{array}{c}\text { Mikkonen et al. } \\
(2001)\end{array}$ & Black currant & $\begin{array}{c}\text { Flavonols (quercetin, } \\
\text { myricetin and } \\
\text { kaempferol) }\end{array}$ & $\begin{array}{c}\text { No consistent differences in the contents of flavonols } \\
\text { were found between the same black currant cultivars } \\
\text { grown in organic and conventional systems. }\end{array}$ \\
\hline
\end{tabular}

A parallel increase in polyphenol content and

Carbonaro et al. (2002)

Peach, pear

Polyphenols, ascorbic and citric acids polyphenoloxidase activity of organic peach and pear as compared with the corresponding conventional samples was found. Ascorbic and citric acids were higher in organic than conventional peaches.

\begin{tabular}{|c|c|c|}
\hline $\begin{array}{l}\text { Asami et al. } \\
\quad(2003)\end{array}$ & $\begin{array}{l}\text { Marionberry, } \\
\text { strawberry, corn }\end{array}$ & $\begin{array}{l}\text { Higher amounts of total phenolic compounds were } \\
\text { found in organic foods compared to the conventional } \\
\text { food. }\end{array}$ \\
\hline $\begin{array}{l}\text { Lombardi- } \\
\text { Boccia et al. } \\
\quad(2004)\end{array}$ & Yellow plums & $\begin{array}{c}\text { Total polyphenols, } \\
\text { phenolic acids, flavonols }\end{array} \quad \begin{array}{c}\text { Total polyphenols content was higher in conventional } \\
\text { plums. Quercetin was higher in conventional plums, } \\
\text { but myrecitin and kaempferol were higher in organic } \\
\text { plums. }\end{array}$ \\
\hline $\begin{array}{l}\text { Dimberg, } \\
\text { Gissén \& } \\
\text { Nilsson }(2005) \\
\end{array}$ & Oats & $\begin{array}{l}\text { No difference resulting was observed for cropping } \\
\text { system. }\end{array}$ \\
\hline $\begin{array}{l}\text { Young et al. } \\
\quad(2005)\end{array}$ & $\begin{array}{l}\text { Leaf lettuce, } \\
\text { collards, pac- } \\
\text { choi }\end{array}$ & $\begin{array}{l}\text { No significant difference was shown for phenolics } \\
\text { concentrations between conventional and organic } \\
\text { lettuce and collard samples. Organic pac choi had } \\
\text { significantly higher phenolic content compared to } \\
\text { conventional pac choi. }\end{array}$ \\
\hline $\begin{array}{l}\text { Chassy et al. } \\
\text { (2006) }\end{array}$ & $\begin{array}{l}\text { Tomatoes, bell } \\
\text { peppers }\end{array}$ & $\begin{array}{l}\text { Organic tomatoes had higher levels of phenolics and } \\
\text { flavonoids compared with conventional tomatoes. }\end{array}$ \\
\hline $\begin{array}{l}\text { Olsson, } \\
\text { Andersson, } \\
\text { Oredsson, } \\
\text { Berglund \& } \\
\text { Gustavsson } \\
\quad(2006)\end{array}$ & $\begin{array}{l}\text { Strawberry, } \\
\text { strawberry } \\
\text { extracts }\end{array}$ & $\begin{array}{l}\text { The antioxidant levels in the organic strawberries were } \\
\text { higher compared to the conventional ones. The ratio of } \\
\text { ascorbate to dehydroascorbate was significantly higher } \\
\text { in the organically cultivated strawberries. Organic } \\
\text { strawberries extract showed higher antiproliferative } \\
\text { activity compared with conventional strawberries. }\end{array}$ \\
\hline $\begin{array}{l}\text { Mitchell et al. } \\
\text { (2007) }\end{array}$ & Tomatoes & $\begin{array}{l}\text { Ten-year mean levels of quercetin and kaempferol in } \\
\text { organic tomatoes were } 79 \text { and } 97 \% \text { higher than those } \\
\text { in conventional tomatoes, respectively. }\end{array}$ \\
\hline $\begin{array}{l}\text { Koh et al. } \\
\text { (2007) }\end{array}$ & $\begin{array}{l}\text { Marinara pasta } \\
\text { sauces }\end{array}$ & $\begin{array}{l}\text { The flavonoid content was not statistically different } \\
\text { between organic and conventional samples. The } \\
\text { content of lycopene was not statistically different } \\
\text { between organic and conventional samples. }\end{array}$ \\
\hline
\end{tabular}




\begin{tabular}{|c|c|c|c|}
\hline Reference & Samples & Compounds analysed & Major conclusions \\
\hline $\begin{array}{c}\text { Wang et al. } \\
\text { (2008) }\end{array}$ & Blueberries & $\begin{array}{l}\text { Antioxidant activity } \\
\text { (ORAC), total phenolics, } \\
\text { total anthocyanins }\end{array}$ & $\begin{array}{c}\text { Fruit grown under organic cultivation yielded } \\
\text { significantly higher malic acid, total phenolics, total } \\
\text { anthocyanins, and antioxidant activity (ORAC) than } \\
\text { fruit from the conventional culture. The organic } \\
\text { culture also yielded fruits with higher contents of } \\
\text { myricetin 3-arabinoside, quercetin 3-glucoside, } \\
\text { delphinidin 3-galactoside, delphinidin 3-glucoside, } \\
\text { delphinidin 3-arabinoside, petunidin 3-galactoside, } \\
\text { petunidin 3-glucoside, and malvidin 3-arabinoside than } \\
\text { conventional culture. }\end{array}$ \\
\hline
\end{tabular}

\begin{tabular}{|c|c|c|c|}
\hline $\begin{array}{l}\text { Lamperi et al. } \\
\text { (2008) }\end{array}$ & Apples & $\begin{array}{c}\text { Total polyphenols } \\
\text { contents, polyphenols } \\
\text { composition, antioxidant } \\
\text { property }\end{array}$ & $\begin{array}{l}\text { Production method did not significantly contribute to } \\
\text { the polyphenol content. Apple peels of both cultivars } \\
\text { of organic fruits showed higher radical scavenging } \\
\text { properties than corresponding ones from integrated } \\
\text { production. }\end{array}$ \\
\hline
\end{tabular}

\begin{tabular}{ccc}
\hline $\begin{array}{c}\text { Dangour et al. } \\
(2009)\end{array}$ & $\begin{array}{c}\text { Many organic and } \\
\text { conventional } \\
\text { crops }\end{array}$ & Titratable acidity \\
\hline $\begin{array}{c}\text { Riahi et al. } \\
(2009)\end{array}$ & Tomato & $\begin{array}{c}\mathrm{pH} \text {, titratable acidity, } \\
\text { lycopene, total phenolic }\end{array}$ \\
\hline $\begin{array}{c}\text { Soltoft et al. } \\
(2010)\end{array}$ & $\begin{array}{c}\text { Onion, carrot, } \\
\text { potato }\end{array}$ & $\begin{array}{c}\text { Flavonoids, phenolic } \\
\text { acids }\end{array}$ \\
& &
\end{tabular}

Organically produced crops were higher in titratable acidity than conventional samples. The production system affected fruit soluble solids,
$\mathrm{pH}$, titratable acidity and firmness only in some cultivars. Tomato lycopene and total phenolic contents were similar between organic and conventional production systems.

In onions and carrots, no statistically significant differences between growth systems were found for any of the analysed polyphenols. A significantly higher content of phenolic 5-caffeoylquinic acid was found in the organic potatoes as compared to the conventional growth system.

\begin{tabular}{ccc}
\hline $\begin{array}{c}\text { Reganold et al. } \\
(2010)\end{array}$ & Strawberries & $\begin{array}{c}\text { Antioxidant activity, } \\
\text { total phenolics }\end{array}$ \\
\hline $\begin{array}{c}\text { Brandt et al. } \\
(2011)\end{array}$ & $\begin{array}{c}\text { Many organic } \\
\text { and } \\
\text { conventional } \\
\text { crops }\end{array}$ & $\begin{array}{c}\text { Secondary metabolites, } \\
\text { carotene }\end{array}$ \\
\hline
\end{tabular}
Organic strawberries had higher antioxidant activity
$(8.5 \%)$ and phenolics $(10.5 \%)$ than conventional berries. Specific polyphenols, such as quercetin and ellagic acid, showed mixed or no differences.

Organic samples had 12\% more secondary metabolites than conventional samples. All groups of secondary metabolites, except carotene and non-defence compounds, were higher in organic than conventional samples.

\begin{tabular}{|c|c|c|}
\hline $\begin{array}{l}\text { Gąstoł et al. } \\
\text { (2011) }\end{array}$ & $\begin{array}{cc}\text { Apple, pear, } & \text { Organic acids, } \\
\text { blackcurrant, } \\
\text { carrot, beetroot } \\
\text { and celery } & \text { polyphenols, antioxidant } \\
& \text { activity } \\
\end{array}$ & $\begin{array}{c}\text { Higher organic acids content was shown in apples, } \\
\text { pears, and especially blackcurrants grown organically. } \\
\text { Organic juices had slightly higher antioxidant activity } \\
\text { and similar levels of polyphenols and ascorbic acid as } \\
\text { conventional juices. }\end{array}$ \\
\hline $\begin{array}{l}\text { Koh et al. } \\
\text { (2012) }\end{array}$ & $\begin{array}{l}27 \text { varieties of } \\
\text { spinach }\end{array}$ & $\begin{array}{l}\text { The mean levels of flavonoids were significantly } \\
\text { higher in the organically grown spinach compared to } \\
\text { the conventionally grown spinach. No significant } \\
\text { effects were observed in the oxalate content of spinach } \\
\text { from either production system. }\end{array}$ \\
\hline $\begin{array}{l}\text { Lombardo et al. } \\
\qquad(2012)\end{array}$ & Total phenolics & $\begin{array}{c}\text { The mean total phenolic content of organic grown } \\
\text { tubers exceeded that of the conventional grown ones } \\
\text { by } 18 \% \text {, although this advantage was cultivar } \\
\text { dependent. }\end{array}$ \\
\hline $\begin{array}{l}\text { Oliveira et al. } \\
\text { (2013) }\end{array}$ & $\begin{array}{l}\text { Antioxidants, enzymes, } \\
\text { phenolic compounds }\end{array}$ & $\begin{array}{l}\text { Higher activity of phenylalanine ammonia lyase, total } \\
\text { phenolics, citric acid, yellow flavonoids, were detected } \\
\text { in organic compared to conventional tomatoes at } \\
\text { harvest. Cell membrane lipid peroxidation degree was } \\
60 \% \text { higher in organic tomatoes. SOD activity was } \\
\text { also dramatically higher in the fruits from organic } \\
\text { farming. }\end{array}$ \\
\hline $\begin{array}{l}\text { Hallmann et al. } \\
\text { (2013) }\end{array}$ & Polyphenols, lycopene & $\begin{array}{l}\text { More total phenolic acid, chlorogenic acid, rutin, p- } \\
\text { coumaric acid, gallic acid, quercetin3-O-glucoside, } \\
\text { total flavonoids, and quercetin was found in organic } \\
\text { tomato juice compared with conventional. The organic } \\
\text { tomato juice contained less lycopene compared to the } \\
\text { non-organic tomato juice. }\end{array}$ \\
\hline
\end{tabular}




\begin{tabular}{|c|c|c|c|}
\hline Reference & Samples & Compounds analysed & Major conclusions \\
\hline $\begin{array}{l}\text { Nunes- } \\
\text { Damaceno et al. } \\
\text { (2013) }\end{array}$ & Kiwis & $\begin{array}{l}\text { Organic acids (oxalic, } \\
\text { quinic, malic, citric } \\
\text { acids), } \mathrm{pH}\end{array}$ & $\begin{array}{l}\text { Significant differences existed only for citric acid } \\
\text { among kiwis of different origins. Organically grown } \\
\text { kiwis had higher citric acid levels than the others. pH } \\
\text { was the lowest in conventionally grown fruit, although } \\
\text { the between-origin differences in pH and titratable } \\
\text { acidity were minimal but significant. }\end{array}$ \\
\hline $\begin{array}{l}\text { Kazimierczak } \\
\text { et al. } \\
\text { (2014) } \\
\end{array}$ & Beetroots & $\begin{array}{l}\text { Total phenolic acids, } \\
\text { flavonoids }\end{array}$ & $\begin{array}{l}\text { The content of total phenolic acids was significantly } \\
\text { higher in conventional beetroots compared with the } \\
\text { organic ones, while the level of flavonoids was similar. }\end{array}$ \\
\hline $\begin{array}{l}\text { Baranski et al. } \\
\text { (2014) }\end{array}$ & $\begin{array}{l}\text { Many organic } \\
\text { and } \\
\text { conventional } \\
\text { crops }\end{array}$ & $\begin{array}{l}\text { Many secondary } \\
\text { metabolites, pigments }\end{array}$ & $\begin{array}{l}\text { Higher concentrations of total flavonoids, total } \\
\text { phenolic acids, flavanones, stilbenes, flavones, } \\
\text { flavonols, kaempferol, xanthophylland total } \\
\text { anthocyanins were found in organic compared to } \\
\text { conventional crops. }\end{array}$ \\
\hline $\begin{array}{l}\text { Brazinskiene et } \\
\text { al. (2014) }\end{array}$ & Potato & Phenolic acids & $\begin{array}{l}\text { Potatoes from organic and conventional systems had } \\
\text { similar phenolic acid content. }\end{array}$ \\
\hline $\begin{array}{l}\text { Vinha et al. } \\
\text { (2014) }\end{array}$ & Tomato & $\begin{array}{l}\text { Total phenolics and } \\
\text { flavonoids, antioxidant } \\
\text { activity }\end{array}$ & $\begin{array}{l}\text { Tomato produced from organic systems were higher in } \\
\text { antioxidant activity, total phenolics and flavonoids, } \\
\text { than those from conventional systems. Tomato } \\
\text { produced from organic systems was higher in lycopene } \\
(+20 \%) \text { than those from conventional systems. }\end{array}$ \\
\hline $\begin{array}{l}\text { Anton et al. } \\
\text { (2014) }\end{array}$ & Tomato & Polyphenols & $\begin{array}{c}\text { Higher contents of apigenin acetylhexoside, caffeic } \\
\text { acid hexoside I, and phloretin dihexoside were found } \\
\text { in all organic samples. The content of polyphenols was } \\
\text { more dependent on year and cultivar than on } \\
\text { cultivation conditions. }\end{array}$ \\
\hline $\begin{array}{l}\text { Kazimierczak } \\
\text { et al. } \\
\text { (2015) }\end{array}$ & $\begin{array}{l}\text { Rosemary, } \\
\text { peppermint, } \\
\text { lemon balm, } \\
\text { sage }\end{array}$ & $\begin{array}{l}\text { Phenolic acids, total } \\
\text { flavonoids, carotenoids }\end{array}$ & $\begin{array}{l}\text { Organic medicinal plants contained significantly more } \\
\text { phenolic acids and total flavonoids than the plants } \\
\text { from conventional production. Conventional medicinal } \\
\text { plants had significantly higher amounts of carotenoids } \\
\text { compared to the organic counterparts. }\end{array}$ \\
\hline
\end{tabular}

\begin{tabular}{ccc}
\hline $\begin{array}{c}\text { Granato, } \\
\text { Margraf, }\end{array}$ & Purple grape & \\
Brotzakis, & juices & Total phenolics \\
$\begin{array}{c}\text { Capuano \& } \\
\text { Van Ruth } \\
(2015)\end{array}$ & & \\
\hline $\begin{array}{c}\text { Khalil \& } \\
\text { Hassan } \\
(2015)\end{array}$ & $\begin{array}{c}\text { Strawberries } \\
\text { and oranges }\end{array}$ & Total phenol content \\
\hline
\end{tabular}

Valverde et al. (2015)

Broccoli

Total phenolics and flavonoids, glucosinolates
Total phenol content was significantly higher in conventional oranges compared to organic production. Total phenol content was significantly higher in organic strawberries than the conventional ones.

Levels of total phenolics and total flavonoids showed a significant year-on-year variation. They were not

significantly different between organic and conventional production systems. Levels of the indolyl glucosinolates glucobrassicin and neoglucobrassicin were higher under organic compared to conventional management.

The organic plums had significantly higher polyphenol and anthocyanin concentrations and a greater antioxidant capacity. Organic plums had greater concentrations of malic, succinic, tartaric, and polyphenols, total anthocyanins, total (2015) carotenoids, antioxidant capacity

shikimic acids than those from conventional orchards. The culture system affected all the studied parameters except for total carotenoid content.

Total phenolic compounds were significantly higher in conventional than organic onions. There were no significant differences in pyruvic acid and flavonoids content between conventional onions and organic onions.

No differences were found for grape seed oil between

Carotenoids 


\begin{tabular}{|c|c|c|c|}
\hline Reference & Samples & Compounds analysed & Major conclusions \\
\hline $\begin{array}{l}\text { De Pascale, } \\
\text { Maggio, Orsini } \\
\text { \& Barbieri } \\
\quad(2016)\end{array}$ & Tomato & $\begin{array}{l}\text { Lipophilic antioxidant } \\
\text { capacity, titratable acidity, } \\
\text { carotenoids }\end{array}$ & $\begin{array}{l}\text { Lipophilic antioxidant capacity was increased under } \\
\text { organic soil fertility management }(25 \%) \text { then } \\
\text { conventional. Titratable acidity was } 20 \% \text { higher in } \\
\text { conventional than organic tomatoes. Carotenoid levels } \\
\text { were increased under organic soil fertility management } \\
\text { (14\%) then conventional. }\end{array}$ \\
\hline $\begin{array}{l}\text { Lee et al. } \\
(2016)\end{array}$ & $\begin{array}{l}\text { Perilla leaves } \\
\quad \text { (Perilla } \\
\text { frutescens } \text { var. } \\
\text { japonica } \text { Hara) }\end{array}$ & $\begin{array}{l}\text { Total phenol, total } \\
\text { flavonoid, GABA, caffeic } \\
\text { acid, rosmarinic acid }\end{array}$ & $\begin{array}{l}\text { Differences between the organic and conventional } \\
\text { production in analysed components were not showed. }\end{array}$ \\
\hline $\begin{array}{l}\text { Suja et al. } \\
\text { (2017) }\end{array}$ & $\begin{array}{l}\text { Taro (Colocasia } \\
\quad \text { esculenta) }\end{array}$ & $\begin{array}{l}\text { Total phenols, dietary } \\
\text { fibres }\end{array}$ & $\begin{array}{l}\text { Conventionally produced taro had higher total phenols } \\
(6.04 \%) \text { and fibres }(19.78 \%) \text { than organic taro. }\end{array}$ \\
\hline $\begin{array}{l}\text { Kapoulas et al. } \\
\qquad(2017)\end{array}$ & Lettuce, onion & $\begin{array}{l}\text { Total phenols content, } \\
\text { total antioxidant capacity }\end{array}$ & $\begin{array}{c}\text { No significant difference in total phenols content } \\
\text { (TPC) was observed between production systems and } \\
\text { growing season in lettuce. } \\
\text { TPC in green onion was higher compared to lettuce. } \\
\text { Similar trend was observed for total antioxidant } \\
\text { capacity. }\end{array}$ \\
\hline $\begin{array}{l}\text { Ren et al. } \\
\text { (2017) }\end{array}$ & Onion & $\begin{array}{c}\text { Total flavonoids, total } \\
\text { anthocyanins, individual } \\
\text { flavonols, individual } \\
\text { anthocyanins, antioxidant } \\
\text { activity } \\
\end{array}$ & $\begin{array}{l}\text { Antioxidant activity (DPPH and FRAP), total flavonol } \\
\text { content, and levels of quercetin 3,4'-diglucoside and } \\
\text { quercetin 3-glucoside were higher in onion varieties } \\
\text { under organic compared to conventional management. }\end{array}$ \\
\hline $\begin{array}{l}\text { Hallmann et al. } \\
\qquad(2017)\end{array}$ & $\begin{array}{l}\text { White cabbage } \\
\text { (Brassica } \\
\text { Oleracea } \mathrm{L} \text {. } \\
\text { var. Capitata })\end{array}$ & $\begin{array}{l}\text { Polyphenols, flavonoids, } \\
\text { chlorophylls, carotenoids }\end{array}$ & $\begin{array}{l}\text { Organic fresh cabbage, compared to the conventional } \\
\text { one, contained significantly less total flavonoids and } \\
\text { several flavonoid compounds. The organic sauerkraut } \\
\text { juice, compared to the conventional one, contained } \\
\text { significantly more total polyphenols as well as several } \\
\text { flavonoids. Organic fresh cabbage, compared to the } \\
\text { conventional one, contained significantly less total } \\
\text { chlorophylls and carotenoids. }\end{array}$ \\
\hline $\begin{array}{l}\text { Golubkina et al. } \\
\qquad(2018)\end{array}$ & $\begin{array}{l}\text { Leek }(\text { Allium } \\
\text { porrum })\end{array}$ & $\begin{array}{l}\text { Polyphenols, antioxidant } \\
\text { activity }\end{array}$ & Management system did not affect polyphenol levels. \\
\hline $\begin{array}{l}\text { Kurubas et al. } \\
\qquad(2018)\end{array}$ & Lettuce & $\begin{array}{l}\text { Antioxidant activity, } \\
\text { titratable acidity, total } \\
\text { phenolic contents }\end{array}$ & $\begin{array}{c}\text { The highest antioxidant activity was obtained from the } \\
\text { organic production system. The conventional } \\
\text { production system had higher total soluble solids, } \\
\text { titratable acidity, and total phenolic contents. }\end{array}$ \\
\hline $\begin{array}{l}\text { Dutra et al. } \\
\quad(2018)\end{array}$ & $\begin{array}{l}\text { Grape juices } \\
\text { and wines }\end{array}$ & $\begin{array}{l}\text { Phenolic profile, } \\
\text { antioxidant activity }\end{array}$ & $\begin{array}{l}\text { Conventional products presented higher anthocyanins } \\
\text { content, and no significant differences were observed } \\
\text { on other phenolic compounds and antioxidant activity. }\end{array}$ \\
\hline $\begin{array}{l}\text { Ribes-Moya et } \\
\text { al. (2018) }\end{array}$ & Peppers & $\begin{array}{l}\text { Total phenolics, total red } \\
\text { and yellow/orange } \\
\text { carotenoids }\end{array}$ & $\begin{array}{l}\text { Organic peppers had more total phenolics than } \\
\text { conventional. Organic peppers had higher content of } \\
\text { total red and yellow/orange carotenoids than } \\
\text { conventional. }\end{array}$ \\
\hline $\begin{array}{l}\text { Martí et al. } \\
\text { (2018) }\end{array}$ & Tomato & Polyphenols & $\begin{array}{l}\text { Organic farming significantly increased the levels } \\
\text { of caffeic acid by } 20 \% \text {, but reduced those of ferulic } \\
\text { acid and naringenin by } 13 \% \text { and } 15 \% \text { respectively. }\end{array}$ \\
\hline $\begin{array}{l}\text { Reche et al. } \\
\text { (2019) }\end{array}$ & Jujube fruit & $\begin{array}{l}\text { Organic acids, flavonoids, } \\
\text { phenols, antioxidant } \\
\text { activity, chlorophylls, } \\
\text { carotenoids }\end{array}$ & $\begin{array}{l}\text { Organic jujubes had higher contents of chlorophylls, } \\
\text { carotenoids, organic acids, and total volatile } \\
\text { compounds, but lower flavonoids than conventional } \\
\text { jujubes. Organic and conventional jujubes had similar } \\
\text { contents of total phenols and antioxidant activity. }\end{array}$ \\
\hline $\begin{array}{l}\text { Picchi et al. } \\
\text { (2019) }\end{array}$ & Plums & Polyphenols & $\begin{array}{l}\text { Organic management resulted in a lower content of } \\
\text { neo-chlorogenic acid compared to the conventional } \\
\text { management. }\end{array}$ \\
\hline $\begin{array}{l}\text { Carrillo, } \\
\text { Wilches-Pérez, } \\
\text { Halman, } \\
\text { Kazimierczak\& } \\
\text { Rembiałkowska } \\
\quad(2019)\end{array}$ & Beetroot & $\begin{array}{l}\text { Phenolic compounds, } \\
\text { total antioxidant capacity, } \\
\text { betalains }\end{array}$ & $\begin{array}{l}\text { Organic and conventional growing systems had similar } \\
\text { average levels of the flavonoids kaempferol-3-O- } \\
\text { glucoside and luteolin in the final products. The } \\
\text { organic beetroot showed significantly higher contents } \\
\text { of total betalains, total polyphenols and higher total } \\
\text { antioxidant capacities, when compared to the } \\
\text { conventionally grown samples. }\end{array}$ \\
\hline
\end{tabular}




\begin{tabular}{|c|c|c|c|}
\hline Reference & Samples & Compounds analysed & Major conclusions \\
\hline $\begin{array}{l}\text { Ponder \& } \\
\text { Hallmann } \\
\text { (2019) }\end{array}$ & $\begin{array}{l}\text { Raspberry } \\
\text { cultivars }\end{array}$ & $\begin{array}{l}\text { Polyphenols, } \\
\text { anthocyanins }\end{array}$ & $\begin{array}{l}\text { The organic samples contained significantly more dry } \\
\text { matter, total anthocyanins and cyanidin-3,5-di-O- } \\
\text { glucoside, phenolic acid and flavonoids, including } \\
\text { myrycetin, quercetin, luteolin and quercetin-3-O- } \\
\text { rutinoside. }\end{array}$ \\
\hline $\begin{array}{l}\text { Pedro et al. } \\
\text { (2019) }\end{array}$ & Goji berry & Organic acids & $\begin{array}{l}\text { Citric acid was greater in conventional goji than } \\
\text { organic. }\end{array}$ \\
\hline $\begin{array}{l}\text { Barcanu-Tudor } \\
\text { et al. } \\
\text { (2020) } \\
\end{array}$ & Bell peppers & Lycopene & $\begin{array}{l}\text { Higher level of lycopene registered in the organic bell } \\
\text { peppers. }\end{array}$ \\
\hline $\begin{array}{l}\text { Guilherme, } \\
\text { Aires, } \\
\text { Rodrigues, } \\
\text { Peres \& Pereira } \\
\quad(2020)\end{array}$ & $\begin{array}{l}\text { Sweet peppers } \\
\text { (green and red) }\end{array}$ & $\begin{array}{l}\text { Phenolic composition, } \\
\text { antioxidant activity }\end{array}$ & $\begin{array}{l}\text { Meta-coumaric acid, ortho-coumaric acid and } \\
\text { quercitin-3-O-rhamnoside were more abundant in } \\
\text { green conventional peppers and chlorogenic acid, } \\
\text { caffeic acid and rutin were found in higher levels in } \\
\text { red organic peppers. Green conventional peppers } \\
\text { showed the highest DPPH, ABTS }{ }^{*+} \text { and total reducing } \\
\text { capacities, while red conventional peppers had higher } \\
\text { TEAC values. }\end{array}$ \\
\hline $\begin{array}{l}\text { Kopczyńska et } \\
\text { al. (2020) }\end{array}$ & Cougette & Polyphenols & $\begin{array}{l}\text { Organic courgette fruits were characterised by their } \\
\text { significantly higher content of phenolic acids and } \\
\text { flavonoids when compared to the conventionally } \\
\text { grown. }\end{array}$ \\
\hline $\begin{array}{l}\text { Hallmann \& } \\
\text { Sabała }(2020)\end{array}$ & $\begin{array}{l}\text { Ocimum } \\
\text { basilicum } \mathrm{L} ., \\
\text { Allium } \\
\text { ursinum } \mathrm{L} ., \\
\text { Origanum } \\
\text { majorana } \mathrm{L} ., \\
\text { Origanum } \\
\text { vulgare } \\
\end{array}$ & $\begin{array}{l}\text { Total polyphenols, } \\
\text { flavonoids, phenolic } \\
\text { acids, chlorophylls }\end{array}$ & $\begin{array}{l}\text { Organic herbs contained significantly higher } \\
\text { concentrations of total polyphenols, flavonoids, and } \\
\text { phenolic acids compared to conventional herbs. } \\
\text { Conventional herbs contained significantly higher } \\
\text { concentrations of chlorophylls. }\end{array}$ \\
\hline $\begin{array}{l}\text { Anjos et al. } \\
\text { (2020) }\end{array}$ & Raspberry & Phenolic $\mathrm{p}$ & $\begin{array}{l}\text { Under organic agricultural practices, the polyphenols } \\
\text { levels increased for the 'Kweli' cultivar but decreased } \\
\text { for the 'Tulameen' cultivar. 'Tulameen' cultivar } \\
\text { grown under conventional agricultural practices } \\
\text { contained higher anthocyanins levels than grown under } \\
\text { organic agricultural practices while for the 'Kweli' } \\
\text { cultivar no significant differences were observed } \\
\text { between the two agricultural practices. }\end{array}$ \\
\hline $\begin{array}{l}\text { Santarelli et al. } \\
\qquad(2020)\end{array}$ & Apples & $\begin{array}{l}\text { Polyphenols, antioxidant } \\
\text { activity }\end{array}$ & $\begin{array}{l}\text { Organic and conventional apples showed a different } \\
\text { profile in free and conjugated polyphenols. Total } \\
\text { phenolic content and antioxidant activity were similar } \\
\text { in organic and conventional apples. }\end{array}$ \\
\hline $\begin{array}{l}\text { Wang et al. } \\
\quad(2020)\end{array}$ & $\begin{array}{l}\text { Triticum } \\
\text { aestivum } \text { vs } T \text {. } \\
\text { spelta flour; } \\
\text { (wholegrain vs } \\
\text { white flour) }\end{array}$ & $\begin{array}{l}\text { Total phenolics and total } \\
\text { flavonoid content, total } \\
\text { antioxidant activity }\end{array}$ & $\begin{array}{l}\text { Phenolic/antioxidant concentrations and activity were } \\
\text { found to be between } 10 \text { and } 33 \% \text { higher in organic vs } \\
\text { conventional flour and between } 2 \text { and } 4.3 \text { times higher } \\
\text { in wholegrain flour compared with white flour. }\end{array}$ \\
\hline
\end{tabular}

It is a polyphenol that is naturally found in the skin of red grapes, berries, plums, peanuts and other plants. As a natural antioxidant, it acts in the body by reducing the aggregation of red blood cells and affects the patency and elasticity of blood vessels, which is of great importance for the healthy functioning of the cardiovascular system.

Winter and Davis (2006) summarised studies comparing organic and conventional foods with respect to nutrient levels, stating that organic production led to the increase of nutrients in plants, especially of organic acids and polyphenolic compounds. Numerous authors reported that organically grown fruits had higher contents of secondary metabolites: polyphenols (Lucarini et al., 1999) and flavonoids (Heaton, 2001) in apples, polyphenol oxidase enzyme activity, total phenolics, organic acids in peaches and pears (Carbonaro et al., 2002), phenolics and ascorbic acid in marionberries and strawberries (Asami et al., 2003), phenolics in organic apple pulp (Veberic et al., 2005), polyphenols, antho-cyanins and total antioxidant activity in oran-ges 
(Tarozzi et al., 2006). In contrast to these authors, Hakkinen and Torronen (2000) claimed that the organic cultivation did not affect the level of phenolic acids and flavonols in strawberries. Similarly, organic production did not significantly affect the level of flavonols in black currants (Mikkonen et al., 2001).

As for vegetables, summarising 400 papers comparing the composition of organically and conventionally produced foods, Heaton (2001) stated that organic potatoes contained higher contents of polyphenols, which is in accordance with the report submitted by Hamouz, Lachman, Vokal and Pivec (1999), while organic tomatoes contained higher contents of lycopene, which is consistent with findings of Caris-Veyrat et al. (2004) that organic tomatoes had more polyphenols, carotenoids and vitamin $\mathrm{C}$. The higher content of polyphe-nols in organic peppers was found by Pérez-López, López-Nicolas, Núñez-Delicado, Del Amor and Carbonell-Barrachina (2007). In a ten-year study about organically and conven-tionally grown tomatoes for a period from 1994 to 2004, Mitchell et al. (2007) estimated statistically higher levels of quercetin and kaempferol aglycones in organic tomatoes. The ten-mean value of quercetin in organic tomatoes amounted to $115.5 \mathrm{mg} / \mathrm{g} \mathrm{d} . \mathrm{m}$., which was higher by $79 \%$ than values in conventional vegetables $(64.6 \mathrm{mg} / \mathrm{g}$ d.m.).

The correspond-ding value of kaempferol amounted to $63.3 \mathrm{mg} / \mathrm{g}$ d.m. which was higher by $97 \%$. Further-more, levels of flavonoids improved over time in samples organically grown. This improve-ment was consistent with the increasing amounts of organic matter in the soil that had been accumulated in organic plots, but also with the decreased application of manure once the soil used for organic farming reached equilibrium levels of organic matter. No signi-ficant difference in polyphenol contents was found between organically and conventionally grown lettuce and collard (Young et al., 2005).

Results gained by Ren, Endo and Hayashi (2001), indicated that organically grown vegetables contained by $30-100 \%$ more flavonoids than conventionally grown vegetables. Moreover, the antioxidant capacity of organic spinach was 2.2 fold-higher than that of conventional spinach, and in some types of onions and Chinese cabbage it was higher by $20 \%$ to $50 \%$. According to Baxter, Graham, Lawrence,
Wiles and Paterson (2001), soups made from organically grown vegetables had a higher content of salicylic acid. Gutierrez et al. (1999) found a higher content of polyphenols in organic olive oil.

According to Golijan and Kostić (2016), cereals contained an abundance of polyphenols and other antioxidants, and due to their unique phytochemical composition, the health benefits of consuming cereals and cereal-based products have been confirmed by numerous medical studies. Maize contains a number of bioactive components with antioxidant and anticancer activities, such as polyphenols of white-seeded maize: ferulic and $\rho$-coumaric acids with their derivatives (Pandey, Singh, Maurya, Singh \& Singh, 2013). It is known that the antioxidant activity is the strongest in maize and then in wheat and oats (Del PozoInsfran, Brenes, Saldivar and Talcott, 2006), whereas buckwheat is considered the best source of polyphenols (Golijan, Živanović \& Kostić, 2017c). Red-, purple- and blue-seeded maize varieties inhibit colorectal carcinogenesis, exhibit antimutagenic activity as well as ability to remove free radicals, which is further associated not only with the contents of polyphenols but also their associated activity with anthocyanins (Lopez-Martinez et al., 2009). According to Koh et al. (2012) organic cropping practices applied in spinach production resulted in decreased levels of nitrates and increased levels of flavonoids and ascorbic acid.

Langenkämper et al. (2006) did not find significant differences in the content of total polyphenols in either organically or conventionally cultivated wheat. However, these authors reported that levels of polyphenols in grains of non-fertilised plants were elevated, suggesting that the increased levels of these compounds could occur under stressful nutrient deficiencies to which the plants had been exposed. A previously performed study on soya bean (Balisteiro, Rombaldi and Genovese, 2013) showed that the distribution of isoflavones differed between organically and conventionally grown plants, whereby there was no unique effect not even within the same class of polyphenolic compounds. According to results obtained by Golijan (2020b), there was no significant difference in the content of total free polyphenols between maize grains grown organically and conventionally, while a higher 
content of free flavonoids was recorded in organic grains. In a similar study conducted with grains of organically and conventionally grown soya bean, Golijan et al. (2018c) found higher content of free polyphenols and flavonoids in conventional grains.

According to Winter and Davis (2006), there are two main hypotheses that explain the increased content of polyphenols and organic acids in organic comestibles in comparison to conventional ones. One hypothesis refers to the effects of various methods of fertilisation on plant metabolism. In conventional farming, synthetic fertilisers are mainly used, providing more accessible nitrogen source to the plants as compared to organic fertilisers. High amounts of nitrogen, easily available through synthetic fertilisers, accelerate the growth and the development of plants, i.e. nitrogen is used for the needs of the plant growth, and as a result, the production of secondary metabolites (organic and amino acids, chlorophyll, polyphenols) is reduced in plants. The second hypothesis refers to the responses of plants to stress conditions of the environment, such as attacks of insects, pathogenic microorganisms, and the presence of weeds. Under conditions of such stress factors, the plant accumulates very important defence secondary metabolites - phytoalexins. Since the use of synthetic pesticides is forbidden in organic farming, with the limited use of permitted chemical substances, plants, in order to increase the level of their protection, consume larger amounts of resources for the synthesis of their own chemical defence mechanisms. The increased production of antioxidants, such as polyphenols, is one of the types of chemical defence mechanisms in plants.

Rembiałkowska (2007) cites hypotheses that explain differences in the metabolite content in plants. The first, carbon-nitrogen balance hypothesis asserts that when nitrogen is easily available to the plant, the plant will first synthesise nitrogen-containing compounds, such as proteins needed for the plant growth and secondary metabolites that contain nitrogen, such as alkaloids, glucosinolates and nonprotein amino acids. Under conditions of reduced availability of nitrogen, the metabolism is redirected to the synthesis of carbonbased compounds, such as starch, cellulose and secondary metabolites without nitrogen, such as polyphenols and terpenoids. According to the second, somewhat newer hypothesis (growth-differentiation balance hypothesis GDBH), the plant permanently monitors the accessibility of available resources and accordingly directs building blocks towards the synthesis of molecules needed for the growth or differentiation, whereby the differentiation is considered to be the synthesis of compounds with a defensive role including many seconddary metabolites, as well as, the synthesis of compounds necessary for the maturation of reproductive organs.

\section{CONCLUSIONS}

Differences in chemical compositions between organically and conventionally produced foods vary in dependence on a plant species, production season, morphological parts of the plant, as well as on observed nutrients, which makes it difficult to draw a single conclusion on the impacts of production methods on the chemical composition of plants and plant-based products. Numerous authors have pointed out that organically grown fruits and vegetables have an improved chemical composition and a higher nutritive value than conventionally grown ones. Their results showed that organic products have significantly less nitrates and proteins, but significantly more dry matter, essential amino acids, sugars, vitamin $\mathrm{C}$, numerous macro-and microelements (particularly $\mathrm{Fe}, \mathrm{Mg}$ and $\mathrm{P}$ ), secondary metabolites and a higher total antioxidant capacity. Contrasting results reported in other studies have indicated the existence of small differences or the absence of differences, while some re searchers have pointed out a higher content of some components in conventional products. Moreover, the lack of a large number of studies related to differences in contents of vitamins, especially $\beta$-carotene and the vitamin B complex, is evident.

Considering the multitude of studies suggesting that the nutritive value of organic food is higher compared to comestibles conventionally produced, a clear consensus does not exist yet, and therefore further research is needed.

\section{REFERENCES}

Acosta-Estrada, B. A., Gutiérrez-Uribe, J. A., \& SernaSaldívar, S. O. (2014). Bound phenolics in foods, a review. Food Chemistry, 152, 46-55. https://doi.org/10.1016/j.foodchem.2013.11.093 
AFSSA. (2003). Report on Evaluation of the nutritional and sanitary quality of organic foods (Evaluation nutritionnelle et sanitaire des aliments issus de l'agriculture biologique, in French) (p. 164).

ANSES, France. http://www.afssa.fr

Aires, A., Carvalho, R., Rosa, E. A. S., \& Saavedra, M. J. (2012).Effects of agriculture production systems on nitrate and nitrite accumulation on baby-leaf salads. Food Science \& Nutrition, 1(1), 3-7. https://doi.org/10.1002/fsn3.1

Alföldi, T., Mader, P., Niggli, U., Spiess, E., Dubois, D., \& Besson, J.-M. (1996). Quality investigation in the long term DOC trial, quality of plant products growth with manure fertilisation. In Proceedings of the Fourth Meeting (pp. 34-43). Institut for Biodynamic Research, Juva Finland.

Alvarez, C. E, Ortega, A., Fernandez, M., \& Borges, A. A. (2001). Growth, yield and leaf nutrient content of organically grown banana plants in the Canary islands. Fruits Paris, 56, 17-26. https://doi.org/10.1051/fruits:2001108

Alvarez, C. E., Carracedo, A. E., Iglesias, E., \& Martinez, M. C. (1993). Pineapples cultivated by conventional and organic methods in a soil from a banana plantation - A comparative study of soil fertility, plant nutrition and yelds. Biological Agriculture and Horticulture, 9, 161-171. https://doi.org/10.1080/01448765.1993.9754629

Anjos, R., Cosme, F., Gonçalves, A., Nunes, F. M., Vilela, A., \& Pinto, T. (2020). Effect of agricultural practices, conventional vs organic, on the phytochemical composition of "Kweli" and "Tulameen" raspberries (Rubus idaeus L.). Food Chemistry, 126833. https://doi.org/10.1016/j.foodchem.2020.126833

Anton, D., Matt, D., Pedastsaar, P., Bender, I., Kazimierczak, R., Roasto, M., Kaart, T., Luik, A., \& Püssa, T. (2014). Three-year comparative study of polyphenol contents and antioxidant capacities in fruits of tomato (Lycopersicon esculentum Mill.) cultivars grown under organic and conventional conditions. Journal of Agricultural and Food Chemistry, 62(22), 5173-80. https://doi.org/10.1021/jf500792k

Asami, D. K., Hong, Y., Barrett, D. M., \& Mitchell, A. E. (2003). Comparison of the total phenolic and ascorbic acid content of freeze-dried and air-dried marionberry, strawberry, and corn grown using conventional, organic, and sustainable methods. Journal of Agricultural and Food Chemistry, 51(5), 1237-1241. https://doi.org/10.1021/jf020635c

Assumpção, C. F., Nunes, I. L., Mendonça, T. A., Bortolin, R. C., Jablonski, A., Flôres, S. H., \& de Oliveira Rios, A. (2015). Bioactive compounds and stability of organic and conventional vitis labrusca grape seed oils. Journal of the American Oil Chemists' Society, 93(1), 115-124. https://doi.org/10.1007/s11746-015-2742-0

Auclair, L., Zee, J. A., Karam, A., \& Rochat, E. (1995). Nutritive value, organoleptic quality and productivity of greenhouse tomatoes in relation to production method: organic - conventional - hydroponic. Sciences des Aliments, 15, 511-528. https://www.researchgate.net/publication/25917582 9_Valeur_nutritive_qualite_organoleptique_et_prod uctivite_des_tomates_de_serre_en_fonction_de_leu r_mode_de_productionbiologique-conventionnelhydroponique

Bach, V., Kidmose, U., Kristensen, H. L., \& Edelenbos, M. (2015). Eating quality of carrots (Daucus carota L.) grown in one conventional and three organic cropping systems over three years. Journal of $A g$ ricultural and Food Chemistry, 63(44), 9803-9811. https://doi.org/10.1021/acs.jafc.5b03161

Balisteiro, D. M., Rombaldi, C. V., \& Genovese, M. I. (2013). Protein, isoflavones, trypsin inhibitory and in vitro antioxidant capacities: Comparison among conventionally and organically grown soybeans. Food Research International, 51, 8-14. https://doi.org/10.1016/j.foodres.2012.11.015

Baranski, M., Srednicka-Tober, D., Volakakis, N., Seal, C., Sanderson, R., Stewart, G. B., Benbrook, C., Biavati, B., Markellou, E., Giotis, C., GromadzkaOstrowska, J., Rembialkowska, E., Skwarlo-Sonta, K., Tahvonen, R., Janovska, D., Niggli, U., Nicot, P., \& Leifert, C. (2014). Higher antioxidant and lower cadmium concentrations and lower incidence of pesticide residues in organically grown crops: a systematic literature review and meta-analyses. British Journal of Nutrition, 112, 794-811. https://doi.org/10.1017/S0007114514001366

Barcanu-Tudor, E., Vinatoru, C., Zamfir, B., Bratu, C., \& Draghici, E. M. (2020). Quantitative and qualitative attributes of two new bell pepper cultivars "Ideal" and "Carmin", grown in conventional and organic farming systems. Acta Horticulture, 1292, 45-52. https://doi.org/10.17660/ActaHortic.2020.1292.6

Baxter, G. J., Graham, A. B., Lawrence, J. R., Wiles, D., \& Paterson, J. R. (2001). Salicylic acid in soups prepared from organically and non-organically grown vegetables. The European Journal of $\mathrm{Nu}$ trition, 40(6), 289-292. https://doi.org/10.1007/s394-001-8358-x

Benbrook, C. M. (2005). Elevating antioxidant levels in food through organic farming and food processing. The Organic Center of Science Review. The Organic Center for Education and Promotion. https://organic-enter.org/reportfiles/AntioxidantReport.pdf

Benbrook, C., Zhao, X., Yáñez, J., Davies, N., \& Andrews, P. (2008). New evidence confirms the nutritional superiority of plant-based organic foods. The Organic Center for Education and Promotion. https://www.organic-center.org/new-evidenceconfirms-nutritional-superiority-plant-basedorganic-foods

Bender, I., Edesi, L., Hiiesalu, I., Ingver, A., Kaart, T., Kaldmäe, H., Talve, T., Tamm, I., \& Luik, A. (2020). Organic carrot (Daucus carota L.) production has an advantage over conventional in quantity as well as in quality. Agronomy, 10(9), 1420. https://doi.org/10.3390/agronomy10091420

Biel, W., Gawęda, D., Jaroszewska, A., \& Hury, G. (2018). Content of minerals in soybean seeds as influenced by farming system, variety and row spacing. Journal of Elementology, 23(3), 863-873. https://doi.org/10.5601/jelem.2017.22.3.1483

Bøhn, T., Cuhra, M., Traavik, T., Sanden, M., Fagan, J., \& Primicerio, P. (2014). Compositional differences in soybeans on the market: Glyphosate accumulates in Roundup Ready GM soybeans. Food Chemistry, 153, 207-215.

https://doi.org/10.1016/j.foodchem.2013.12.054 
Bordeleau, G., Myers-Smith, I., Midak, M., \& Szeremeta, A. (2002). Food Quality: A comparison of organic and conventional fruits and vegetables. Ecological Agriculture Den Kongelige Veterinœr- og Landbohøjskole. https://edepot.wur.nl/115486

Bourn, D. M. (1994). The nutritional value of organically and conventionally grown food: is there a differrence? In Proceedings of the Nutrition Society of New Zealand, 19, 51-57.

Bourn, D., \& Prescott, J. (2002). A comparison of the nutritional value, sensory qualities, and food safety of organically and conventionally produced foods. Critical Reviews in Food Science and Nutrition, 42(1), 1-34. https://doi.org/10.1080/10408690290825439

Brandt, D. A., Brand, T. S., \& Cruywagen, C. W. (2000). The use of crude protein content to predict concentrations of lysine and methionine in grain harvested from selected cultivars of wheat, barley and triticale grown in the Western Cape region of South Africa. South African Journal of Animal Science, 30(1), 22-25. http://dx.doi.org/10.4314/sajas.v30i1.3870

Brandt, K., \& Mølgaard, J. P. (2001). Organic agriculture: does it enhance or reduce the nutritional value of plant foods? Journal of the Science of Food and Agriculture, 81, 924-931. https://doi.org/10.1002/jsfa.903

Brandt, K., Leifert, C., Sanderson, R., \& Seal, C. J. (2011). Agroecosystem Management and Nutritional Quality of Plant Foods: The Case of Organic Fruits and Vegetables. Critical Reviews in Plant Sciences, 30(1-2), 177-197. https://doi.org/10.1080/07352689.2011.554417

Brazinskiene, V., Asakaviciute, R., Miezeliene, A., Alencikiene, G., Ivanauskas, L., Jakstas, V., Viskelis, P. \& Razukas, A. (2014). Effect of farming systems on the yield, quality parameters and sensory properties of conventionally and organically grown potato (Solanum tuberosum L.) tubers. Food Chemistry, 145, 903-909. https://doi.org/10.1016/j.foodchem.2013.09.011

Carbonaro, M., Matterra, M., Nicoli, S., Bergamo, P., \& Cappelloni, M. (2002). Modulation of antioxydant compounds in organic vs. conventional fruit (peach, Prunus persica L., and pear, Pyrus communis L.). Journal of Agricultural and Food Chemistry, 50(19), 5458-5462. https://doi.org/10.1021/jf0202584

Carillo, P., Cacace, D., De Pascale, S., Rapacciuolo, M., \& Fuggi, A. (2012). Organic vs. traditional potato powder. Food Chemistry, 133(4), 1264-1273. https://doi.org/10.1016/j.foodchem.2011.08.088

Caris-Veyrat, C., Amiot, M. J., Tyssandier, V., Grasselly, D., Buret, M., Mikolajczak, M., Guilland, J. C., Bouteloup-Demange, C., \& Borel, P. (2004). Influence of organic versus conventional agricultural practice on the antioxidant microconstituent content of tomatoes and derived purees; consequences on antioxidant plasma status in humans. Journal of Agricultural and Food Chemistry, 52(21), 65036509. https://doi.org/10.1021/jf0346861

Carrillo, C., Wilches-Pérez, D., Halman, E., Kazimierczak, R., \& Rembiałkowska, E. (2019). Organic versus conventional beetroot. Bioactive compounds and antioxidant properties. $L W T, 108552$. https://doi.org/10.1016/j.lwt.2019.108552
Caruso, G., Villari, G., Borrelli, C., \& Russo, G. (2012). Effects of crop method and harvest seasons on yield and quality of green asparagus under tunnel in southern Italy. Advances in Horticultural Science, 26(2), 51-58. http://www.jstor.org/stable/42882867

Chakhovskii, I. A. (1981): Use of fertilizers and the quality of wheat protein. Voprosy Pitaniia, 4, 48-52. https://europepmc.org/article/med/6270910\#abstract

Chassy, A. W., Bui, L., Renaud, E. N. C., Van Horn, M., \& Mitchell, A. E. (2006). Three-year comparison of the content of antioxidant microconstituents and several quality characteristics in organic and conventionally managed tomatoes and bell peppers. Journal of Agricultural and Food Chemistry, 54(21), 8244-8252. https://doi.org/10.1021/jf060950p

Ciolek, A., Makarska, E., Wesolowski, M., \& Cierpiala, R. (2012). Content of selected nutrients in wheat, barley and oat grain from organic and conventional farming. Journal of Elementology, 17(2), 181-189. https://doi.org/10.5601/jelem.2012.17.2.02

Clarke, R. P., \& Merrow, S. B. (1979). Nutrient composition of tomatoes homegrown under different cultural procedures. Ecology and Food Nutrition 8, $37-46$. https://doi.org/10.1080/03670244.1979.9990543

Codron, J. M., Siriex, L., \& Reardon, T. (2006). Social and environmental attributes of food products in an emerging mass market: Challenges of signaling and consumer perception, with European illustra-tions. Agriculture and Human Values, 23(3), 283-297. https://doi.org/10.1007/s10460-006-9000-x

Colla, G., Cardona Suarez, C. M., Cardanelli, M., \& Rouphael, Y. (2010): Improving nitrogen use efficiency in melon by grafting. Hort Science, 45, 559-565. https://doi.org/10.21273/HORTSCI.45.4.559

Cuevas, F. J., Pradas, I., Ruiz-Moreno, M. J., Arroyo, F. T., Perez-Romero, L. F., Montenegro, J. C., \& Moreno-Rojas, J. M. (2015). Effect of organic and conventional management on bio-functional quality of thirteen plum cultivars (Prunus salicina Lindl.). PLOS ONE, 10(8), e0136596. https://doi.org/10.1371/journal.pone.0136596

Dangour, A. D, Dodhia, S. K., Hayter, A., Allen, E., Lock, K., \& Uauy, R. (2009). Nutritional quality of organic foods: a systematic review. The American Journal of Clinical Nutrition, 90(3), 680-685. https://doi.org/10.3945/ajcn.2009.28041

De Pascale, S., Maggio, A., Orsini, F., \& Barbieri, G. (2016). Cultivar, soil type, nitrogen source and irrigation regime as quality determinants of organically grown tomatoes. Scientia Horticulturae, 199, 88-94. https://doi.org/10.1016/j.scienta.2015.12.037

De Souza Araújo, D. F., da Silva, A. M. R. B., de Andrade Lima, L. L., da Silva Vasconcelos, M. A., Andrade, S. A. C., \& Asfora Sarubbo, L. (2014). The concentration of minerals and physicochemical contaminants in conventional and organic vegetables. Food Control, 44, 242-248. https://doi.org/10.1016/j.foodcont.2014.04.005

DeEll, J. R., \& Prange, R. K. (1993). Postharvest physiological disorders, diseases and mineral concentrations of organically and conventionally grown McIntosh and Cortland apples. Canadian Journal of Plant Science, 73, 223-230. 
https://doi.org/10.4141/cjps93-036

Del Pozo-Insfran, D., Brenes, C. H., Saldivar, S. O. S., \& Talcott, S. T. (2006). Polyphenolic and antioxidant content of white and blue corn (Zea mays L.) products. Food Research International, 39(6), 696703. https://doi.org/10.1016/j.foodres.2006.01.014

Dimberg, L. H., Gissén, C., \& Nilsson, J. (2005). Phenolic compounds in oat grains (Avena sativa L.) grown in conventional and organic systems. Ambio, 34(4-5), 331-337. https://doi.org/10.1639/00447447(2005)034[0331:pcioga]2.0.co;2

Dlouhy, J. (1977). The quality of plant products conventional and bio-dynamic management. BioDynamics, 124, 28-32.

Dos Santos, A. M. P., Lima, J. S., dos Santos, I. F., Silva, E. F. R., de Santana, F. A., de Araujo, D. G. G. R., $\&$ dos Santos, L. O. (2017). Mineral and centesimal composition evaluation of conventional and organic cultivars sweet potato (Ipomoea batatas (L.) Lam) using chemometric tools. Food Chemistry, 273(1), 166-171.

https://doi.org/10.1016/j.foodchem.2017.12.063

Dutra, M. da C. P., Rodrigues, L. L., de Oliveira, D., Pereira, G. E., \& Lima, M. dos S. (2018). Integrated analyses of phenolic compounds and minerals of Brazilian organic and conventional grape juices and wines: Validation of a method for determination of $\mathrm{Cu}, \mathrm{Fe}$ and Mn. Food Chemistry, 269, 157165.https://doi.org/10.1016/j.foodchem.2018.07.014

Eppendorfer, W. H., \& Eggum, B. O. (1996). Fertilizer effects on yield, mineral and amino acid composition, dietary fibre content and nutritive value of leeks. Plant Foods for Human Nutrition, 49, 163 174. https://doi.org/10.1007/BF01091974

Eppendorfer, W. H., Eggum, B. O., \& Bille, S. W. (1979). Nutritive value of potato crude protein as influenced by manuring and amino acid composition. Journal of the Science of Food and Agriculture, 30, 361-368.

https://doi.org/10.1002/jsfa.2740300404

European Commission (2008). Commission Regulation (EC) No. 629/2008 of 2 July 2008 amending Regulation (EC) No. 1881/2006 setting maximum levels for certain contaminants in foodstuffs. The Official Journal of the European Union, L173, 6-9.

Fewtrell, L. (2004). Drinking-water nitrate, methemoglobinemia, and global burden of disease: A discussion. Environmental Health Perspectives, 112(14), 1371-1374. https://doi.org/10.1289/ehp.7216

FiBL (2020). The World of Organic Agriculture 2020. FiBL \& IFOAM Organics International. https://www.fibl.org/fileadmin/documents/shop/50 11-organic-world-2020.pdf Access: 2.1.2021.

Finesilver, T., Johns, T., \& Hill, S. B. (1989). Comparison of food quality of organically versus conventionally grown plant foods. Ecological Agriculture Projects Publication, 37. Montreal, Canada: MacDonald College, McGill University

Fischer, A., \& Richter, C. (1986). Influence of organic and mineral fertilisers on yield and quality of potatoes. In Proceedings of the $5^{\text {th }}$ IFOAM International Scientific Conference: The Importance of Biological Agriculture in a World of Diminishing Resources, 1984 (pp. 236-248). University of Kassel, Germany. https://agris.fao.org/agris-

search/search.do?recordID=US201302691075

Fjelkner-Modig, S., Bengtsson, H., Stegmark, R., \& Nystrom, S. (2000). The influence of organic and integrated production on nutritional, sensory and agricultural aspects of vegetable raw materials for food production. Acta Agriculturae Scandinavica, Section B-Soil \& Plant Science, 50, 102-113. https://doi.org/10.1080/090647100750374250

Freedman, M. R., \& Mirabrishami, M. (2015).Vitamin C Content of Refrigerated, Commercially Available Orange Juice From Organically Grown and Conventionally Grown Oranges Is Not Different. Nutrition Today, 50(6), 306-309. https://doi.org/10.1097/nt.0000000000000126

Gąstoł, M., \& Domagala-Świątkiewicz, I. (2013). Comparing nutritional content of fruits, vegetables and juices from organic and conventional crops. $C A B$ Reviews, 8 (060), 1-10. http://dx.doi.org/10.1079/PAVSNNR20138060

Gąstoł, M., Domagała-Świątkiewicz, I., \& Krośniak, M. (2011). Organic versus conventional - a comparative study on quality and nutritional value of fruit and vegetable juices. Biological Agriculture \& Horticulture, 27(3-4), 310-319.

https://doi.org/10.1080/01448765.2011.648726

Golijan, J. (2020a). The influence of production methods on vigour and chemical composition of maize, spelt and soybean seeds (PhD thesis). The University of Belgrade, Faculty of Agriculture, Belgrade, Serbia.

Golijan, J. (2020b). Content of free polyphenols and flavonoids in organic and conventionally produced maize seed (Zea mays). In Book of Abstracts of the IX International Symposium on Agricultural Sciences, (AgroRes 2020), (pp. 25), Banja Luka, Bosnia and Herzegovina. https://agrores.net/wp-content/uploads/2020/09/AGRORES-2020-Book-ofAbstracts.pdf

Golijan, J. M., Kostić, A. Ž., Dojčinović, B. P, Milinčić, D. D., Pešić, M. B., \& Lekić, S. S. (2019b). Content of selected toxic elements in organic and conventional maize seed. In Book of abstracts of the VIII International Symposium on Agricultural Sciences, (AgroRes 2019), (pp. 37) Trebinje, Bosnia and Herzegovina.

http://agro.unibl.org/wp-content/uploads/2019/06/Bookof-Abstracts-AgroReS-2019.pdf

Golijan, J. M., Lekić, S. S., Vuković, G., \& Sečanski, M. D. (2020). Presence of aflatoxins and deoxynivalenol in seeds of maize, spelt wheat and soya bean - preliminary research. Matica srpska Journal of Natural Sciences, 139, 19-28. https://doi.org/10.2298/ZMSPN2039019G

Golijan, J., \& Dimitrijević, B. (2018). Global organic food market. Acta Agriculturae Serbica, 23(46), 125-140. https://scindeks-clanci.ceon.rs/da-ta/pdf/03549542/2018/0354-95421846125G.pdf

Golijan, J., \& Kostić, Ž. A. (2016). Značaj polifenola iz žitarica u ljudskoj ishrani. Hrana i ishrana, 57(2), 47-52.

https://scindeks-clanci.ceon.rs/data/pdf/-00186872/2016/0018-68721602047G.pdf

Golijan, J., \& Veličković, M. (2015). Nutritivni sastav organski i konvencionalno proizvedenih namirnica. Hrana i ishrana, 56(2), 43-46. https://scindeks-clanci.ceon.rs/data/pdf/00186872/2015/0018-68721502043G.pdf 
Golijan, J., Kostić, A. Ž., Dojčinović, B. P., \& Lekić, S. (2018b). Determination of iron and zinc content in organic and conventional spelt seed (Triticum spelta). In Book of Abstracts of the Sixth Conference of Young Chemists of Serbia, (pp. 15). Belgrade, Serbia. ttps://www.scribd.com/document/425121798/Bookof-Abstracts-CD-Sa-Cipom

Golijan, J., Kostić, A. Ž., Pešić, M. B., Stanojević, S. P., Barać, M. B., \& Lekić, S. (2017a). Content of soluble sugars in cereals and soybean seeds grown under different conditions. In Book of Abstracts of the $28^{\text {th }}$ International scientific-expert conference of agriculture and food industry (pp. 103). Sarajevo, Bosnia and Herzegovina.

https://ppf.unsa.ba/Aktuelnosti/Book\%20of\%20Abs tracts\%202017.pdf

Golijan, J., Kostić, A., \& Lekić, S. (2017b). Toxic metal health risk assessment in organic and conventional grown cereals/pseudocereals and soybean seed samples. In Book of Abstracts of the $54^{\text {th }}$ Meeting of the Serbian Chemical Society and $5^{\text {th }}$ Conference of Young Chemists Of Serbia (p. 102). Belgrade, Serbia. https://www.shd.org.rs/54SHD/54SHD 5KMHS.pdf

Golijan, J., Milinčić, D., Kostić, A. Ž., Popović, D. A., Pešić, M. B., Barać, M. B., \& Lekić, S. (2018c). Determination of free polyphenol and flavonoids content in organic and conventionally produced soybean seed (Glycine max L.). In Book of Abstracts of the UNIFood Conference, (p. 48). Belgrade, Serbia.

https://www.researchgate.net/profile/Jose_Pinela/publicati on/327942103_Stability_of_ascorbic_acid_tocopherols_an d_total_folates_in_irradiated_buckler_sorrel_leaves_durin g_refrigerated_storage/links/5bbe580092851c4efd5622e1/ Stability-of-ascorbic-acid-tocopherols-and-total-folates-inirradiated-buckler-sorrel-leaves-during-refrigeratedstorage.pdf

Golijan, J., Živanović, LJ., \& Kostić, Ž. A. (2017c). Hemijski sastav heljde sa nutritivnog aspekta. Hrana $i$ ishrana, 58(2), 9-16.

https://scindeks-članci.ceon.rs/data/pdf/00186872/2017/0018-68721702009G.pdf

Golijan, M. J., Kostić, A. Ž., Dojčinović, B. P., \& Lekić, S. S. (2018a). Determination of $\mathrm{Zn}$ and $\mathrm{Fe}$ content in organic and conventionally grown seeds using Inductively Coupled Plasma-Optical Emission Spectrometry (ICP-OES). In Book of abstracts of the $7^{\text {th }}$ International Symposium on Agricultural Sciences, (AgroRes 2018), (p. 75), Banja Luka, Bosnia and Herzegovina. https://agrores.net/wp-content/uploads/2020/01/AGRORES-2018-Book-of-Abstracts.pdf

Golijan, J. M., Kostić, A. Ž., Dojčinović, B. P., Milinčić, D.D., Pešić, M. B., Barać, M. B., \& Lekić, S. S. (2019a). Determination of microelements in organic and conventional produced buckweat seeds (Fagopyrum esculentum) using ICP-OES. In Book of Abstracts of the $30^{\text {th }}$ International Scientific-Expert Conference of Agriculture and Food Industry (p.34). Sarajevo, Bosnia and Herzegovina.

Golubkina, N., Seredin, T., Antoshkina, M., Kosheleva, O., Teliban, G., \& Caruso, G. (2018). Yield, quality, antioxidants and elemental composition of new leek cultivars under greenhouse organic or conventional system. Horticulturae, 4(4), 39. https://doi.org/10.3390/horticulturae4040039
Gorenjak, A. H., Koležnik, U. R., \& Cencič, A. (2012). Nitrate content in dandelion (Taraxacum officinale) and lettuce (Lactuca sativa) from organic and conventional origin: intake assessment. Food Additives and Contaminants: Part B, 5(2), 93-99. https://doi.org/10.1080/19393210.2012.658873

Granato, D., Margraf, T., Brotzakis, I., Capuano, E., \& Van Ruth, S. M. (2015). Characterization of conventional, biodynamic, and organic purple grape juices by chemical markers, antioxidant capacity, and instrumental taste profile. Journal of Food Science, 80(1), 55-65. https://doi.org/10.1111/17503841.12722

Guilherme, R., Aires, A., Rodrigues, N., Peres, A. M., \& Pereira, J. A. (2020). Phenolics and antioxidant activity of green and red sweet peppers from organic and conventional agriculture: A comparative study. Agriculture, 10(12), 652. https://doi.org/10.3390/agriculture10120652

Gutierrez, F., Arnaud, T., \& Albi, M. A. (1999). Influence of ecological cultivation on virgin olive oil quality. Journal of the American Oil Chemists' Society, 76, 617-621. https://doi.org/10.1007/s11746-999-0012-8

Hakkinen, S. H., \& Torronen, A. R. (2000). Content of flavonols and selected phenolic acids in strawberries and Vaccinium species: influence of cultivar, cultivation site andtechnique. Food Research International, 33(6), 517-524. https://doi.org/10.1016/S0963-9969(00)00086-7

Hallmann, E., \& Sabała, P. (2020). Organic and conventional herbs quality reflected by their antioxidant compounds concentration. Applied Sciences, 10(10), 3468. https://doi.org/10.3390/app10103468

Hallmann, E., Kazimierczak, R., Marszałek, K., Drela, N., Kiernozek, E., Toomik, P., Matt, D., Luik, A., \& Rembiałkowska, E. (2017). The nutritive value of organic and conventional white cabbage (Brassica Oleracea L. Var. Capitata) and anti-apoptotic activity in gastric adenocarcinoma cells of sauerkraut juice produced therof. Journal of Agricultural and Food Chemistry, 65(37), 8171-8183. https://doi.org/10.1021/acs.jafc.7b01078

Hallmann, E., Lipowski, J., Marszałek, K., \& Rembiałkowska, E. (2013). The Seasonal Variation in Bioactive Compounds Content in Juice from Organic and Non-organic Tomatoes. Plant Foods for Human Nutrition, 68(2), 171-176. https://doi.org/10.1007/s11130-013-0352-2

Hamouz, K., Lachman, J., Vokal, B., \& Pivec, V. (1999). Influence of environmental conditions and way of cultivation on the polyphenol and ascorbic acid content in potato tubers. Rostlinna Vyroba, 45, 293298.

https://agris.fao.org/agrissearch/search.do?recordID $=\mathrm{CZ} 1999001203$

Hansen, H. (1981). Comparision of chemical composition and taste of biodynamically and conventionally grown vegetables. Plant Foods Human Nutrition, 30, 203-2011. https://doi.org/10.1007/BF01094025

Harcz, P., De Temmerman, L., De Voghel, S., Waegeneers, N., Wilmart, O., Vromman, V., Schmit, J-F, Moons, E., Van Peteghem, C., De Saeger, S., Schneider, Y-J., Larondelle, Y., \& Pussemier, L. (2007). Contaminants in organically and conventionally produced winter wheat (Triticum aestivum) 
in Belgium. Food Additives and Contaminants, 24(7), 713-720.

https://doi.org/10.1080/02652030601185071

Heaton, S. (2001). Organic Farming, Food Quality and Human Health: A Review of the Evidence. Bristol: Soil Association.

https://www.soilassociation.org/media/4920/policy _report_2001_organic_farming_food_quality_huma n_health.pdf

Hoefkens, C., Vandekinderen, I., De Meulenaer, B., Devlieghere, F., Baert, K., Sioen, I., De Henauw, S., Verbeke, W., \&Van Camp, J. (2009). A literature-based comparison of nutrient and contaminant contents between organic and conventional vegetables and potatoes. British Food Journal, $111(10), 1078-1097$.

https://doi.org/10.1108/00070700910992934

Hogstad, S., Risvik, E., \& Steinsholt, K. (1997). Sensory quality and chemical composition in carrots: a multivariate study. Acta Agricultuarae Scandanavica Section B, Soil and Plant Science 47(4), 253264. https://doi.org/10.1080/09064719709362469

Hoogenboom, L. A. P., Bokhorst, J. G., Northolt, M. D., van de Vijver, L. P. L., Broex, N. J. G., Mevius, D. J., Meijs, J. A. C., \& Van der Roest, J. (2008). Contaminants and microorganisms in Dutch organic food products: a comparison with conventional products. Food Additives \& Contaminants: Part A, 25(10), 1195-1207. https://doi.org/10.1080/02652030802014930

Hornick, S. B. (1992). Factors affecting the nutritional quality of crops. American Journal of Alternative Agriculture, 7, 63-8.

https://www.jstor.org/stable/44479652

http://polj.uns.ac.rs/sites/default/files/letopisnaucnih-

radova/7\%20\%C5\%A0ereme\%C5\%A1i\%C4\%87\% 20et\%20al.\%20PR\%20Ann\%20Agron.\%2041\%282 $\% 29 . p d f$

Ilić, Z., Kapoulas, N., Sunic, L., Bekovic, D., \& Mirecki, N. (2014). Heavy elements and nitrate content in tomato fruit grown in organic and conventional production systems. Polish Journal of Environmental Studies, 23(6), 2027-2032. https://doi.org/10.15244/pjoes/23922

Ismail, A., \& Fun, C. S. (2003). Determination of Vitamin $\mathrm{C}, \mathrm{b}$-carotene and riboflavin contents in five green vegetables organically and conven-tionally grown. Malaysian Journal of Nutrition, 9(1), 31-39. https://pubmed.ncbi.nlm.nih.gov/22692530

Kalinova, J., \& Vrchotova, N. (2011). The influence of organic and conventional crop management, variety and year on the yield and flavonoid level in common buckwheat groats. Food Chemistry, 127(2), 602-608. https://doi.org/10.1016/j.foodchem.2011.01.050

Kapoulas, N., Koukounaras, A., \& Ilić, Z. S. (2017). Nutritional quality of lettuce and onion as companion plants from organic and conventional production in north Greece. Scientia Horticulturae, 219, 310-318. https://doi.org/10.1016/j.scienta.2017.03.027

Kazimierczak, R., Hallmann, E., \& Rembiałkowska, E. (2015). Effects of organic and conventional production systems on the content of bioactive substances in four species of medicinal plants. Biolo- gical Agriculture \& Horticulture, 31(2), 118-127. https://doi.org/10.1080/01448765.2014.977948

Kazimierczak, R., Hallmann, E., Lipowski, J., Drela, N., Kowalik, A., Pussa, T., Matt, D., Luik, A., Gozdowski, D., \& Rembiałkowska, E. (2014). Beetroot (Beta vulgaris L.) and naturally fermented beetroot juices from organic and conventional production: metabolomics, antioxidant levels and anticancer activity. Journal of the Science of Food and Agriculture, 94(13), 2618-2629. https://doi.org/10.1002/jsfa.6722

Khalil, H. A., \&Hassan, S. M. (2015). Ascorbic acid, $\beta$ carotene, total phenolic compound and microbial quality of organic and conventional citrus and strawberry grown in Egypt. African Journal of Biotechnology, 14(4), 272. https://doi.org/10.5897/AJB2014.14170

Koh, E., Charoenprasert, S., \& Mitchell, A. E. (2012). Effect of Organic and Conventional Cropping Systems on Ascorbic Acid, Vitamin C, Flavonoids, Nitrate, and Oxalate in 27 Varieties of Spinach (Spinacia oleracea L.). Journal of Agricultural and Food Chemistry, 60(12), 3144-3150. https://doi.org/10.1021/jf300051f

Koh, E., Wimalasiri, K. M., Renaud, E. N., \& Mitchell, A. E. (2007). A comparison of flavonoids, carotenoids and vitamin $\mathrm{C}$ in commercial organic and conventional marinara pasta sauce. Journal of the Science of Food and Agriculture, 88(2), 344-354. https://doi.org/10.1002/jsfa.3097

Kolbe, H., Meineke, S., \& Zhang, W. L. (1995). Differences in organic and mineral fertilisation on potato tuber yield and chemical composition compared to model calculations. Agribiological Research (Germany), 48, 63-73.

https://agris.fao.org/agrissearch/search.do?recordID=DE9620349

Konvalina, P., Stehno, Z., Capouchová, I., \& Moudry, J. (2011). Wheat growing and quality in organic farming. In R. Nokkoul (Ed.) Research in organic farming, (pp. 105-122). London, UK: InTechOpen. https://orgprints.org/20757/1/InTechWheat_growing_and_quality_in_organic_farming.pdf

Kopczyńska, K., Kazimierczak, R., Średnicka-Tober, D., Barański, M., Wyszyński, Z., Kucińska, K., Perzanowska, A., Szacki, P., Rembiałkowska, E., \& Hallmann, E. (2020). The profile of selected antioxidants in two courgette varieties from organic and conventional production. Antioxidants, 9(5), 404. https://doi.org/10.3390/antiox9050404

Kouřimská, L., Kubaschová, K., \& Sus, J. (2014). Comparison of the carbohydrate content in apples and carrots grown in organic and integrated farming systems. Potravinarstvo, 8(1), 178-183. https://www.potravinarstvo.com/journal1/index.php /potravinarstvo/article/view/362/pdf

Kramer, S. B., Reganold, J. P., Glover, J. D., Bohannan, B. J. M., \& Mooney, H. A. (2006). Reduced nitrate leaching and enhanced denitrifier activity and efficiency in organically fertilized soils. Proceedings of the National Academy of Sciences, 103(12), $4522-4527$. https://doi.org/10.1073/pnas.0600359103

Kumpulainen, J. (2001). Organic and conventional grown foodstuffs: Nutritional and toxicological quality comparisons. In Proceedings of the International Fertiliser Society, 472, (pp. 1-20). Lisbon, Portugal. 
https://agris.fao.org/agrissearch/search.do?recordID=US201300062841

Kurubas, M. S., Maltas, A. S., Dogan, A., Kaplan, M., \& Erkan, M. (2018). Comparison of organically and conventionally produced Batavia type lettuce stored in modified atmosphere packaging for postharvest quality and nutritional parameters. Journal of the Science of Food and Agriculture, 99(1), 226-234. https://doi.org/10.1002/jsfa.9164

Kwiatkowski, C. A., \& Harasim, E. (2020). Chemical properties of soil in four-field crop rotations under organic and conventional farming systems. Agronomy, 10(7), 1045. https://doi.org/10.3390/agronomy10071045

Lairon, D. (2010). Nutritional quality and safety of organic food. A review. Agronomy for Sustainable Development, 30(1), 33-41. https://doi.org/10.1051/agro/2009019

Lairon, D., Spitz, N., Termine, E., Ribaud, P., Lafont, H., \& Hauton, J. (1984). Effect of organic and mineral nitrogen fertilization on yield and nutritive value of butterhead lettuce. Plant Foods for Human $\mathrm{Nu}$ trition, 34, 97-108.

https://doi.org/10.1007/BF01094837

Lairon, D., Termine, E., Gautier, S., Trouilloud, M., Lafont, H., \& Hauton, J. (1986). Effects of organic and mineral fertilisations on the contents of vegetables in minerals, vitamin $\mathrm{C}$ and nitrates. In Proceedings of the 5th IFOAM International Scientific Conference: The Importance of Biological Agriculture in a World of Diminishing Resources -(pp. 249-260). University of Kassel, Germany. https://agris.fao.org/agrissearch/search.do?recordID=US201302691076

Lamperi, L., Chiuminatto, U., Cincinelli, A., Galvan, P., Giordani, E., Lepri, L., \& Del Bubba, M. (2008). Polyphenol levels and free radical scavenging activities of four apple cultivars from integrated and organic farming in different Italian areas. Journal of Agricultural and Food Chemistry, 56(15), 65366546. https://doi.org/10.1021/jf801378m

Langenkämper, G., Zörb, C., Seifert, M., Mäder, P., Fretzdorff, B., \& Betsche, T. (2006). Nutritional quality of organic and conventional wheat. Journal of Applied Botany and Food Quality, 80, 150-154. https://www.researchgate.net/profile/Mathias_Seifer t/publication/286625751_Nutritional_quality_of_or ganic_and_conventional_wheat/links/566c993208ae $62 \mathrm{~b} 05 \mathrm{f} 088 \mathrm{~b} 2 \mathrm{~b} /$ Nutritional-quality-of-organic-andconventional-wheat.pdf

Laursen, K. H., Mihailova, A., Kelly, S. D., Epov, V. N., Bérail, S., Schjoerring, J. K., Donard, O. F. X., Larsen, E. H., Pedentchouk, N., Marca-Bell, A. D., Halekoh, U., Olesen, J. E., \& Husted, S. (2013). Is it really organic? - Multi-isotopic analysis as a tool to discriminate between organic and conventional plants. Food Chemistry, 141(3), 2812-2820. https://doi.org/10.1016/j.foodchem.2013.05.068

Laursen, K. H., Schjoerring, J. K., Olesen, J. E., Askegaard, M., Halekoh, U., \& Husted, S. (2011). Multielemental Fingerprinting as a Tool for Authentication of Organic Wheat, Barley, Faba Bean, and Potato. Journal of Agricultural and Food Chemistry, 59(9), 4385-4396.

https://doi.org/10.1021/jf104928r
Lecerf, J. M. (1995). L'agriculture biologique. Interet en nutrition humaine? Cahiers de Nutrition et de Diététique, 30, 349-357.

Leclerc, J., Miller, M. L., Joliet, E., \& Rocquelin, G. (1991). Vitamin and mineral contents of carrot and celeriac under mineral or organic fertilization. Biological Agriculture \& Horticulture, 7, 349-361. https://doi.org/10.1080/01448765.1991.9754564

Lee, J., Hwang, S., Ha, I., Min, B., Hwang, H., \& Lee, S. (2015). Comparison of bulb and leaf quality and antioxidant compounds of intermediate-day onion from organic and conventional systems. Horticulture, Environment, and Biotechnology, 56(4), 427436. https://doi.org/10.1007/s13580-015-1036-7

Lee, M. W., Choi, E. B., Park, J. E., Kim, S. C., Lee, S. B., Sim, C. K., Lee, Y-B., Hong, C. O., \& Kim, K. K. (2016). Analysis of functional components of the perilla leaves (Perilla frutescens var. japonica Hara) Grown in Organic and Conventional Conditions. Korean Journal of Soil Science and Fertilizer, 49(5), 517-523. https://doi.org/10.7745/KJSSF.2016.49.5.517

Lee, S. K., \& Kader, A. A. (2000). Preharvest and postharvest factors influencing vitamin $\mathrm{C}$ content of horticultural crops. Postharvest Biology and Technology, 20(3), 207-220. https://doi.org/10.1016/S0925-5214(00)00133-2

Levite, D., Adrian, M., \& Tamm, L. (2000). Preliminary results of resveratrol in wine of organic and conventional vineyards. In Proceedings of the 6th International Congress on organic Viticulture (pp. 256-257). Basel (Suisse).

https://orgprints.org/9107/1/1\%C3\%A9vite-etal-2000-winecongress.pdf

Lima, G. P. P., Lopes, T. do V. C., Rossetto, M. R. M., \& Vianello, F. (2009). Nutritional composition, phenolic compounds, nitrate content in eatable vegetables obtained by conventional and certified organic grown culture subject to thermal treatment. International Journal of Food Science \& Technology, 44(6), 1118-1124. https://doi.org/10.1111/j.1365-2621.2009.01928.x

Liu, B., Tu, C., Hu, S., Gumpertz, M., \& Ristaino, J. B. (2007). Effect of organic, sustainable, and conventional management strategies in grower fields on soil physical, chemical, and biological factors and the incidence of Southern blight. Applied Soil Ecology, 37(3), 202-214. https://doi.org/10.1016/j.apsoil.2007.06.007

Locascio, S. J., Wilkbank, W. J., Gull, D. D., \& Maynard, D. N. (1984). Fruit and vegetable quality as affected by nitrogen nutrition. In R. D. Hauck (Ed.), Nitrogen in Crop Production (pp. 617-626). Madison, WI: American Society of Agronomy. https://doi.org/10.2134/1990.nitrogenincropproduct ion.c42

Lockeretz, W., Shearer, G., \& Kohl, D. H. (1981). Organic farming in the Corn Belt. Science, 211, 540-547. https://doi.org/10.1126/science.211.4482.540

Lombardi-Boccia, G., Lucarini, M., Lanzi, S., Aguzzi, A., \& Cappelloni, M. (2004). Nutrients and Antioxidant Molecules in Yellow Plums (Prunus domestica L.) from Conventional and Organic Productions: A Comparative Study. Journal of Agricultural and Food Chemistry, 52(1), 90-94. https://doi.org/10.1021/jf0344690 
Lombardo, S., Pandino, G., \& Mauromicale, G. (2012). Nutritional and sensory characteristics of "early" potato cultivars under organic and conventional cultivation systems. Food Chemistry, 133 (4), 12491254. https://doi.org/10.1016/j.foodchem.2011.10.005

Lopez-Martinez, L. X., Oliart-Ros, R. M., Valerio Alfaro, G., Lee, C. H., Parkin, K. L., \& Garcia, H. S. (2009). Antioxidant activity, phenolic compounds and anthocyanins content of eighteen strains of Mexican maize. LWT-Food Science and Technology, 42(6), 1187-1192. https://doi.org/10.1016/j.lwt.2008.10.010

Lucarini, M., Carbonaro, M., Nicoli, S., Aguzzi, A., Cappelloni, M., Ruggeri, S., Di Lullo, G., Gambelli, L., \& Carnovale, E. (1999). Endogenous markers for organic versus conventional plant products, In M. Hägg, R. Ahvenainen \& A. M. Evers, K. (Eds.), Agri - Food Quality II: Quality Management of Fruits and Vegetables (pp. 306-310), Woodhead Publishing.

Mäder, P., Hahn, D., Dubois, D., Gunst, L., Alföldi, T., Bergmann, H., Oehme, M., Amado, R., Schneider, H., Graf, U., Velimirov, A., Fließbach, A., \& Niggli, U. (2007). Wheat quality in organic and conventional farming: results of a 21 year field experiment. Journal of the Science of Food and Agriculture, 87, 1826-1835. https://doi.org/10.1002/jsfa.2866

Magkos, F., Arvaniti, F., \& Zampelas, A. (2003). Organic food: nutritious food or food for thought? A review of the evidence. International Journal of Food Sciences and Nutrition, 54(5), 357-371. https://doi.org/10.1080/09637480120092071

Marques Vieira, L., Dutra De Barcellos, M., Hoppe, A., \& Bitencourt da Silva, S. (2013). An analysis of value in an organic food supply chain. British Food Journal, 115(10), 1454-1472. https://doi.org/10.1108/BFJ-06-2011-0160

Martí, R., Leiva-Brondo, M., Lahoz, I., Campillo, C., Cebolla-Cornejo, J., \& Roselló, S. (2018). Polyphenol and L-ascorbic acid content in tomato as influenced by high lycopene genotypes and organic farming at different environments. Food Chemistry, 239, 148-156.

https://doi.org/10.1016/j.foodchem.2017.06.102

McCollum, J. P. (1956). Sampling tomato fruits for composition studies. Proceedings of the American Society for Horticultural Science, 68, 587-595. https://edepot.wur.nl/444068

Mikkonen, T. P., Määttä, K. R., Hukkanen, A. T., Kokko, H. I., Törrönen, A. R., Kärenlampi, S. O., \& Karjalainen, R. O. (2001). Flavonol content varies among black currant cultivars. Journal of Agricultural and Food Chemistry, 49(7), 3274-3277. https://doi.org/10.1021/jf0010228

Millard, P. (1986). The nitrogen content of potato (Solanum tuberosum L.) tubers in relation to nitrogen application - the effect on amino acid composition and yields. Journal of the Science Food and Agriculture, 37, 107-114. https://doi.org/10.1002/jsfa.2740370203

Mirecki, N., Wehinger, T., \& Jaklič, M., (Eds.) (2011). Priručnik za organsku proizvodnju. Biotehnički fakultet Podgorica. http://www.fao.org/3/an443sr/an443sr00.pdf
Mitchell, A. E., Hong, Y. J., Koh, E., Barrett, D. M., Bryant, D. E., Denison, R. F., \& Kaffka, S. (2007). Ten-year comparison of the influence of organic and conventional crop management practices on the content of flavonoids in tomatoes. Journal of Agricultural and Food Chemistry, 55(15), 6154-6159. https://doi.org/10.1021/jf070344+

Mozafar, A. (1993). Nitrogen fertilizers and the amount of vitamins in plants: A review. Journal of plant nutrition, 16, 2479-506. https://doi.org/10.1080/01904169309364698

Mozafar, A. (1996). Decreasing the $\mathrm{NO}_{3}$ and increasing the vitamin $\mathrm{C}$ contents in spinach by a nitrogen deprivation method. Plant Foods for Human Nutrition, 49, 155-162. https://doi.org/10.1007/BF01091973

Nunes-Damaceno, M., Muñoz-Ferreiro, N., RomeroRodríguez, M. A., \& Vázquez-Odériz, M. L. (2013). A comparison of kiwi fruit from conventional, integrated and organic production systems. LWT - Food Science and Technology, 54(1), 291-297. https://doi.org/10.1016/j.lwt.2013.05.002

Nuñez de González, M. T., Osburn, W. N., Hardin, M. D., Longnecker, M., Garg, H. K., Bryan, N. S., \& Keeton, J. T. (2015). A Survey of Nitrate and Nitrite Concentrations in Conventional and Organic-Labeled Raw Vegetables at Retail. Journal of Food Science, 80(5), C942-C949. https://doi.org/10.1111/1750-3841.12858

Oliveira, A. B., Moura, C. F. H., Gomes-Filho, E., Marco, C. A., Urban, L., \& Miranda, M. R. A. (2013). The Impact of Organic Farming on Quality of Tomatoes Is Associated to Increased Oxidative Stress during Fruit Development. PLoS ONE, 8(2), e56354. doi:10.1371/journal.pone.0056354

Olsson, M. E., Andersson, C. S., Oredsson, S., Berglund, R. H., \& Gustavsson, K-E. (2006). Antioxidant Levels and Inhibition of Cancer Cell Proliferation in Vitro by Extracts from Organically and Conventionally Cultivated Strawberries. Journal of Agricultural and Food Chemistry, 54(4), 1248-1255. https://doi.org/10.1021/jf0524776

Owen, R. W., Giacosa, A., Hull, W. E., Haubner, R., Spiegelhalder, B., \& Bartsch, H. (2000). The antioxidant/anticancer potential of phenolic compounds isolated from olive oil. European Journal of Cancer, 36, 1235-1247. https://doi.org/10.1016/S0959-8049(00)00103-9

Pandey, R., Singh, A., Maurya, S., Singh, U. P., \& Singh, M. (2013). Phenolic acids in different preparations of Maize (Zea mays) and their role in human health. International Journal of Current Microbiology and Applied Science, 2(6), 84-92.

https://www.ijcmas.com/vol-27/Rachna\%20Pandey,\%20et\%20al.pdf

Pedro, A. C., Sánchez-Mata, M-C., Pérez-Rodríguez, M. L., Cámara, M., López-Colón, J. L., Bach, F., Bellettini, M., \& Haminiuk, C. W. I. (2019). Qualitative and nutritional comparison of goji berry fruits produced in organic and conventional sys-tems. Scientia Horticulturae, 257, 108660. https://doi.org/10.1016/j.scienta.2019.108660

Perez-Llamas, F., Navarro, I., Marin, J. F., Madrid, J. A., \& Zamora, S. (1996). Comparative study on the nutritive quality of foods grown organically and conventionally. Alimentaria, 34, 41-44. 
Pérez-López, A. J., López-Nicolas, J. M., Núñez-Delicado, E., Del Amor, F. M., \& Carbonell-Barrachina, A. A. (2007). Effects of agricultural practices on color, carotenoids composition, and minerals contents of sweet peppers, cv. Almuden. Journal of Agricultural and Food Chemistry, 55(20), 81588164. https://doi.org/10.1021/jf071534n

Picchi, V., Lo Scalzo, R., Kurze, E., Fibiani, M., Vangdal, E., \& Schwab, W. (2019). Impact of year of harvest, genotype and cultivation method on bioactives and Pru d 1 allergen content in plums. International Journal of Food Sciences and $\mathrm{Nu}$ trition, 70, 1-13. https://doi.org/10.1080/09637486.2018.1557606

Pimpini, F., Giardini, L., Borin, M., \& Gianquinto, G. (1992). Effects of poultry manure and mineral fertilisers on the quality of crops. Journal of Agricultural Science, 118(2), 215-221. https://doi.org/10.1017/S0021859600068817

Pither, R., \& Hall, M. N. (1990). Analytical survey of the nutritional composition of organically grown fruit and vegetables. Technical Memorandum, Campden Food \& Drink Research Association, 597.

Ponder, A., \& Hallmann, E. (2019). The effects of organic and conventional farm management and harvest time on the polyphenol content in different raspberry cultivars. Food Chemistry, 125295. https://doi.org/10.1016/j.foodchem.2019.125295

Popović, A., Golijan, J., Babić, V., Kravić, N., Sečanski, M., \& Delić, N. (2016). Organic farming as a factor for biodiversity conservation. In Book of Abstracts of the International scientific conference on Ecological crisis: Technogenesis and climate chain, ( $\mathrm{p}$. 61), Belgrade, Serbia.

Popović, A., Golijan, J., Sečanski M., \& Čamdžija, Z. (2017). Current status and prospects of organic production of cereals in the world. In Book of Abstracts of the $6^{\text {th }}$ International Symposium on Agricultural Science, (AgroRes 2017), (pp. 102), Banja Luka, Bosnia and Herzegovina.

https://agrores.net/wpcontent/uploads/2020/01/AGRORES-2017-Bookof-Abstracts.pdf

Ragasits, I., \& Kismanyoky, T. (2000). Effects of organic and inorganic fertilization on wheat quality. Növény termelés, 49, 527-532.

https://www.cabdirect.org/cabdirect/abstract/20013 144236

Reche, J., Hernández, F., Almansa, M. S., CarbonellBarrachina, Á. A., Legua, P., \& Amorós, A. (2019). Effects of organic and conventional farming on the physicochemical and functional properties of jujube fruit. $L W T, 99,438-444$. https://doi.org/10.1016/j.lwt.2018.10.012

Reganold, J. P., \& Wachter, J. M. (2016). Organic agriculture in the twenty-first century. Nature Plants, 2, 15221. https://doi.org/10.1038/NPLANTS.2015.221

Reganold, J. P., Andrews, P. K., Reeve, J. R., CarpenterBoggs, L., Schadt, C. W., Alldredge, J. R., Ross, C. F., Davies, N. M., \& Zhou, J. (2010). Fruit and soil quality of organic and conventional strawberry agroecosystems. PLoS ONE, 5(9), e12346. https://doi.org/10.1371/journal.pone.0012346

Reganold, J. P., Glover, J. D., Andrews, P. K., \& Hinman, H. R. (2001). Sustainability of three apple production systems. Nature Magazine, 410, 926930. https://doi.org/10.1038/35073574

Reinken, G. (1986). Six years of biodynamic growing of vegetables and apples in comparison with the conventional farm management. In H. Vogtmann, E. Boehncke \& I. Fricke (Eds.), The Importance of Biological Agriculture in a World of Diminishing Resources/Proceedings of the 5th IFOAM International Scientific Conference (pp. 161-174), Witzenhausen, Germany. https://agris.fao.org/agrissearch/search.do?recordID=US201302691070

Rembialkowska, E. (1998). A comparison of selected parameters of potatoes health quality from ecologically oriented and conventional farms. Roczniki Państwowego Zakladu Higieny, 49, 159-167. http://agro.icm.edu.pl/agro/element/bwmeta1.eleme nt.agro-article-96c0b56e-68de-439d-bf3719f551205809?q=bwmeta1.element.agro-number735ea24d-7d27-431d-9948$6 \mathrm{cbc} 360315 \mathrm{c} 1 ; 2 \& \mathrm{qt}=\mathrm{CHILDREN}-\mathrm{STATELESS}$

Rembiałkowska, E. (2000). Wholesomeness and sensory quality of potatoes and selected vegetables from the organic farms. Fundacja Rozw’oj SGGW, Warszawa, Poland.

Rembiałkowska, E. (2007). Quality of plant products from organic agriculture. Journal of the Science of Food and Agriculture, 87, 2757-2762. https://doi.org/10.1002/jsfa.3000

Rembiałkowska, E., Załęcka, A., Badowski, M., \& Ploeger, A. (2012). The quality of organically produced food. In P. Konvalina (Ed.) Organic farming and food production, London, UK: IntechOpen.

https://www.intechopen.com/books/organic-farming-andfood-production/the-quality-of-organically-produced-food

Ren, F., Reilly, K., Kerry, J. P., Gaffney, M., Hossain, M., \& Rai, D. K. (2017). Higher antioxidant activity, total flavonols, and specific quercetin glucosides in two different onion (Allium cepa L.) varieties grown under organic production: results from a 6-year field study. Journal of Agricultural and Food Chemistry, 65(25), 5122-5132. https://doi.org/10.1021/acs.jafc.7b01352

Ren, H., Endo, H., \& Hayashi, T. (2001). Antioxidative and antimutagenic activities and polyphenol content of pesticide-free and organically cultivated green vegetables using water-soluble chitosan as a soil modifi er and leaf surface spray. Journal of the Science of Food and Agriculture, 81(15), 14261432. https://doi.org/10.1002/jsfa.955

Riahi, A., Hdider, C., Sanaa, M., Tarchoun, N., Kheder, M.B., \& Guezal, I. (2009). Effect of conventional and organic production systems on the yield and quality of field tomato cultivars grown in Tunisia. Journal of the Science of Food and Agriculture, 89, 2275-2282. https://doi.org/10.1002/jsfa.3720

Ribes-Moya, A. M., Raigón, M. D., Moreno-Peris, E., Fita, A., \& Rodríguez-Burruezo, A. (2018). Response to organic cultivation of heirloom Capsicum peppers: Variation in the level of bioactive compounds and effect of ripening. PLOS ONE, 13(11), e0207888.

https://doi.org/10.1371/journal.pone.0207888

Rossetto, M. R. M., Vianello, F., Saeki, M. J., \& Lima, G. P. P. (2015). Polyamines in conventional and organic vegetables exposed to exogenous ethylene. Food Chemistry, 188, 218-224. 
https://doi.org/10.1016/j.foodchem.2015.04.125

Roussos, P. A., \& Gasparatos, D. (2009). Apple tree growth and overall fruit quality under organic and conventional orchard management. Scientia Horticulturae, 123, 247-252. https://doi.org/10.1016/j.scienta.2009.09.011

Ryan, M. H., Derrick, J. W., \& Dann, P. R. (2004). Grain mineral concentrations and yield of wheat grown under organic and conventional management. Journal of Science of Food and Agriculture, 84, 207216. https://doi.org/10.1002/jsfa.1634

Santamaria, P. (2006). Nitrate in vegetables: toxicity, content, intake and EC regulation. Journal of the Science of Food and Agriculture, 86, 10-17. https://doi.org/10.1002/jsfa.2351

Santarelli, V., Neri, L., Sacchetti, G., Di Mattia, C. D., Mastrocola, D., \& Pittia, P. (2020). Response of organic and conventional apples to freezing and freezing pre-treatments: Focus on polyphenols content and antioxidant activity. Food Chemistry, 308, 125570.

https://doi.org/10.1016/j.foodchem.2019.125570

Schreiner, M. (2005). Vegetable crop management strategies to increase the quantity of phytochemicals. European Journal of Nutrition, 44(2), 8594. https://doi.org/10.1007/s00394-004-0498-7

Schuphan, W. (1972). Effects of the application of inorganic and organic manures on the market quality and on the biological value of agricultural products. Plant Foods for Human Nutrition, 21, 381-398. https://doi.org/10.1007/BF01099605

Schuphan, W. (1974). Nutritional value of crops as influenced by organic and inorganic fertilizer treatments. Plant Foods for Human Nutrition, 23, 333-358. https://doi.org/10.1007/BF01095422

Shier, N. W., Kelman, J., \& Dunson, J. W. (1984). A comparison of crude protein, moisture, ash and crop yield between organic and conventionally grown wheat. Nutrition Reports International, 30, 71-76. https://agris.fao.org/agrissearch/search.do?recordID=US8622361

Skrabule, I., Muceniece, R., \& Kirhnere, I. (2013). Evaluation of vitamins and glycoalkaloids in potato genotypes grown under organic and conventional farming systems. Potato Research, 56, 259-276. https://doi.org/10.1007/s11540-013-9242-0

Smith, B. (1993). Organic food vs. supermarket food: element levels. Journal of Applied Nutrition, 45, 3539.

https://www.soilandhealth.org/wp-

content/uploads/01aglibrary/Arun/Organic\%20vs\%20supe rmarket--element\%20levels.pdf

Smith-Spangler, C. M., Brandeau, M. L., Hunter, G. E., Bavinger, J., Pearson, M., Eschbach, P. J., Sundaram, V., Liu, H., Schirmer, P., Stave, C., Olkin, I., \& Bravata, D. M. (2012). Are organic foods safer or healthier than conventional alternatives? Annals of Internal Medicine, 157, 348. https://doi.org/10.7326/0003-4819-157-5201209040-00007

Soltoft, M., Nielsen, J., Laursen, K. H., Husted, S., Halekoh, U., \& Knuthsen, P. (2010). Effects of organic and conventional growth systems on the content of flavonoids in onions and phenolic acids in carrots and potatoes. Journal of Agricultural and Food Chemistry, 58, 10323-10329. https://doi.org/10.1021/jf101091c
Starling, W., \& Richards, M. C. (1990). Quality of organically grown wheat and barley. Aspects of Applied Biology, 25, 193-198.

https://www.cabdirect.org/cabdirect/abstract/19922 313943

Starling, W., \& Richards, M. C. (1993). Quality of commercial samples of organically grown wheat. Aspects of applied biology, 36, 205-209. https://agris.fao.org/agrissearch/search.do?recordID=GB9407914

Storey, T., Hogan, R., \& Humphreys, J. (1993). The growth, yield and quality of winter wheat and winter oats grown under an organic conversion regime. Aspects of Applied Biology, 36, 199-204. https://agris.fao.org/agrissearch/search.do?recordID=GB9407898

Suja, G., Byju, G., Jyothi, A. N., Veena, S. S., \& Sreekumar, J. (2017). Yield, quality and soil health under organic vs conventional farming in taro. Scientia Horticulturae, 218, 334-343. https://doi.org/10.1016/j.scienta.2017.02.006

Šarčević-Todosijević, Lj., Petrović, B., Vukomanović, P., Živanović, Lj., Garčić, J., \& Popović, V. (2019). Antimicrobial activity of plant secondary metabolites. In Proceedings of the XXIV Conference on biotechnology with international participation (pp. 357-364). Cačak, Serbia.

afc.edu.rs/files/data/sb/zbornik/Zbornik_radova_1_SB2019.pdf

Šeremešić, S., Vojnov, B., Manojlović, M., Milošev, D., Ugrenović, V., Filipović, V. \& Babec, B. (2017). Organska poljoprivreda u službi biodiverziteta i zdravlja. Letopis naučnih radova, 41(2), 51-60.

Tan, C. C., Wang, Y. P., \& Lee, C. C. (1998). Effect of organic fertilizers on nitrate, $\mathrm{Cu}$ and $\mathrm{Zn}$ contents in vegetables. Journal of Agriculture and Forestry, 47, 107-114.

Tarozzi, A., Hrelia, S., Angeloni, C., Morroni, F., Biagi, P., Guardigli, M., Cantelli-Forti, G., \& Hrelia, P. (2006). Antioxidant effectiveness of organically and non-organically grown red oranges in cell culture systems. European Journal of Nutrition, 45(3), 152158. https://doi.org/10.1007/s00394-005-0575-6

Termine, E., Lairon, D., Taupier-Letage, B., Gautier, S., Lafont, R., \& Lafont, H. (1987). Yield and content in nitrates, minerals and ascorbic acid of leeks and turnips grown under mineral or organic nitrogen fertilizations. Plant Foods for Human Nutrition, 37, 321-332. https://doi.org/10.1007/BF01092208

Tõnutare, T., Keert, K., Szajdak, L., \& Moor, U. (2014). Composition of commercially produced organic and conventional_strawberries. Nutrition \& Food Science, 44(6), 562-575.

https://doi.org/10.1108/NFS-12-2013-0151

Tuomisto, H. L., Hodge, I. D., Riordan, P., \& Macdonald, D. W. (2012).Does organic farming reduce environmental impacts? - A meta-analysis of European research. Journal of Environmental Management, 112, 309-320.

https://doi.org/10.1016/j.jenvman.2012.08.018

Uckoo, R. M., Jayaprakasha, G. K., \& Patil, B. S. (2015). Phytochemical analysis of organic and conventionally cultivated Meyer lemons (Citrus me-yeri Tan.) during refrigerated storage. Journal of Food Composition and Analysis, 42, 63-70. https://doi.org/10.1016/j.jfca.2015.01.009 
Valverde, J., Reilly, K., Villacreces, S., Gaffney, M., Grant, J., \& Brunton, N. (2015). Variation in bioactive content in broccoli (Brassica oleracea var. italica) grown under conventional and organic production systems. Journal of the Science of Food and Agriculture, 95(6), 1163-1171. https://doi.org/10.1002/jsfa.6804

Veberic, R., Trobec, M., Herbinger, K., Hofer, M., Grill, D., \& Stampar, F. (2005). Phenolic compounds in some apple (Malus domestica Borkh) cultivars of organic and integrated production. Journal of the Science Food and Agriculture, 85, 1687-1694. https://doi.org/10.1002/jsfa.2113

Vinha, A. F., Barreira, S. V. P., Costa, A. S. G., Alves, R. C., \& Oliveira, M. B. P. P. (2014). Organic versus conventional tomatoes: Influence on physicochemical parameters, bioactive compounds and sensorial attributes. Food and Chemical Toxicology, 67, 139-144. https://doi.org/10.1016/j.fct.2014.02.018

Vinković Vrček, I., Vitali Čepo, D., Rašić, D., Peraica, M., Žuntar, I., Bojić, M., Mendaš, G., \& MedićŠarić, M. (2014). A comparison of the nutritional value and food safety of organically and conventionally produced wheat flours. Food Chemistry, 143, 522-529. https://doi.org/10.1016/j.foodchem.2013.08.022

Vogtmann, H., Temperli, A. T., Kunsch, U., Eichenberger, M., \& Ott, P. (1984). Accumulation of nitrates in leafy vegetables grown under contasting agricultural systems. Biological Agriculture \& Horticulture, 2, 51-68. https://doi.org/10.1080/01448765.1984.9754414

Vrček, V., \& Vinković Vrček, I. (2012). Metals in organic and conventional wheat flours determined by an optimised and validated ICP-MS method. International Journal of Food Science \& Technology, 47(8), 1777-1783 https://doi.org/10.1111/j.1365-2621.2012.03034.x

Wang, J., Chatzidimitriou, E., Wood, L., Hasanalieva, G., Markelou, E., Iversen, P. O., Seala, C., Baranski, M., Vigar, V., Ernst, L., Willson, A., Thapa, M., Barkla, B., Leifert, C., \& Rempelos, L. (2020). Effect of wheat species (Triticum aestivum vs $T$. spelta), farming system (organic vs conventional) and flour type (wholegrain vs white) on composition of wheat flour - Results of a retail survey in the UK and Germany - 2. Antioxidant activity, and phenolic and mineral content. Food Chemistry: $X, 6,100091$. https://doi.org/10.1016/j.fochx.2020.100091

Wang, S. Y., Chen, C-T., Sciarappa, W., Wang, C. Y., \& Camp, M. J. (2008). Fruit quality, antioxidant capacity, and flavonoid content of organically and conventionally grown blueberries. Journal of Agricultural and Food Chemistry, 56(14), 5788-5794. https://doi.org/10.1021/jf703775r

Warman, P. R. \& Harvard, K. A. (1998). Yield, vitamin and mineral content of organically and conventionally grown potatoes and sweet corn. Agriculture, Ecosystems and Environment, 68(3), 207213. https://doi.org/10.1016/S0167-8809(97)00102-3

Warman, P. R., \& Havard, K. A. (1996). Yield, vitamin and mineral content of four vegetables grown with either composted manure or conventional fertilizer. Journal of Vegetable Crop Production, 2, 13-25. https://doi.org/10.1300/J068v02n01_03
Wawrzyniak, A., Kwiatkowski, S., \& Gronowska-Senger, A. (1997). Evaluation of nitrate, nitrite and total protein content in selected vegetables cultivated conventionally and ecologically. Roczniki Państwowego Zaktadu Higieny, 48, 179-186. https://pubmed.ncbi.nlm.nih.gov/10628224/

Weibel, F. P., Bickel, R., Leuthold, S., \& Alföldi, T. (2000). Are organically grown apples tastier and healthier? A comparative field study using conventional and alternative methods to measure fruit quality. Acta Horticulturae, 517, 417-426. https://doi.org/10.17660/ActaHortic.2000.517.53

Williams, C. M. (2002). Nutritional quality of organic food: shades of grey or shades of green? Proceedings of the Nutrition Society, 61, 19-24. https://doi.org/10.1079/PNS2001126

Winter, C. K. \& Davis, S. F. (2006). Organic foods. Journal of Food Science, 71, 117-124. https://doi.org/10.1111/j.1750-3841.2006.00196.x

Woëse, K., Lange, D., Boess, C., \& Bogl, K. W. (1997). A comparison of organically and conventionally grown foods - results of a review of the relevant literature, Journal of the Science Food and Agriculture, 74, 281-293. https://doi.org/10.1002/(SICI)10970010(199707)74:3<281::AID-JSFA794>3.0.CO;2$\mathrm{Z}$

Wolff, I. A., \& Wasserman, A. E. (1972). Nitrates, nitrites and nitrosamines. Science, 177 (4034), 15-19. https://www.jstor.org/stable/1733909

Wolfson, J. L., \& Shearer, G. (1981). Amino acid composition of grain protein grown with and without pesticides and standard commercial fertilizers. Agronomy Journal, 73, 611-613. https://doi.org/10.2134/agronj1981.000219620073000400 $10 \mathrm{x}$

Worthington, V. (1998). Effect of agricultural methods on nutritional quality: a comparison of organic with conventional crops. Alternative Therapies in Health and Medicine, 4, 58-69. https://pubmed.ncbi.nlm.nih.gov/9439021/

Worthington, V. (2001). Nutritional quality of organic versus conventional fruits, vegetables, and grains. Journal of Alternative and Complimentary Medicine, 7(2), 161-173. https://doi.org/10.1089/107555301750164244

Xu, H. L, Wang, R., Mridha, M. A. U., Goyal, S., \& Umemura, H. (2000). Yield and quality of leafy vegetables with organic fertilizations. In Proceedings of the $13^{\text {th }}$ IFOAM International Scientific Conference the World Grows Organic, IFOAM 2000 (p. 277). Zürich, Switzerland. https://www.cabdirect.org/cabdirect/abstract/20000 315049

Young, J. E., Zhao, X., Carey, E. E., Welti, R., Yang, SS., \& Wang, W. (2005). Phytochemical phenolics in organically grown vegetables. Molecular Nutrition \& Food Research, 49(12), 1136-1142. https://doi.org/10.1002/mnfr.200500080

Yu, X., Guo, L., Jiang, G., Song, Y., \& Muminov, M. A. (2018). Advances of organic products over conventional productions with respect to nutritional quality and food security. Acta Ecologica Sinica, $38,53-60$.

https://doi.org/10.1016/j.chnaes.2018.01.009

Zhang, Y., Cao, S., Zhang, Z., Meng, X., Hsiaoping, C., Yin, C., Jiang, H., \& Wang, S. (2019). Nutritional 
quality and health risks of wheat grains from organic and conventional cropping systems. Food Chemistry, 308, 125584.

https://doi.org/10.1016/j.foodchem.2019.125584

Zhang, Z. B., Jiao, Z. P., Li, H. Y., \& Lei, H. (2014). Comparison of mineral elements in organic and traditional black sesame. ChemBioEng, 31(5), 72-74.

Zörb, C., Langenkämper, G., Betsche, T., Niehaus, K., \& Barsch, A. (2006). Metabolite profiling of wheat grains (Triticum aestivum L.) from organic and con- ventional agriculture. Journal of Agriculture and Food Chemistry, 54, 8301-8306.

https://doi.org/10.1021/jf0615451

Zörb, C., Niehaus, K., Barsch, A., Betsche, T., \& Langenkämper, G. (2009). Levels of compounds and metabolites in wheat ears and grains in organic and conventional agriculture. Journal of Agricul-tural and Food Chemistry, 57(20), 9555-9562.

https://doi.org/10.1021/jf9019739 


\title{
ORGANSKI BILJNI PROIZVODI IMAJU BOLJI HEMIJSKI SASTAV OD KONVENCIONALNIH PROIZVODA
}

\author{
Jelena M. Golijan*1 ${ }^{1}$ Mile D. Sečanski ${ }^{2}$
}

${ }^{1}$ Univerzitet u Beogradu, Poljoprivredni fakultet, 11080 Beograd, Nemanjina 6, Srbija

${ }^{2}$ Institut za kukuruz Zemun Polje, 11185 Beograd, Slobodana Bajića 1, Srbija

Sažetak: S obzirom na negativne efekte do kojih dovodi konvencionalna poljoprivredna proizvodnja, organska proizvodnja hrane predstavlja održiv pristup proizvodnje, koji čuva životnu sredinu i zravlje ljudi. Organski proizvodi su proizvodi visokog stepena kvaliteta, bez ostataka pesticida $\mathrm{i}$ drugih štetnih hemikalija. $\mathrm{U}$ ovom radu je kroz pregled literaturnih podataka dat prikaz poređenja hemijskog sastava organskih i konvencionalnih biljaka i njihovih proizvoda. Izdvojeni su: suva materija, nitrati, proteini, šećeri, vitamini, makro- i mikroelementi, kao i sekundarni metaboliti. Podaci ukazuju da organski proizvodi u odnosu na konvencionalne imaju više suve materije, znatno manje nitrata, manje proteina uz veći udeo esencijalnih aminokiselina, više šećera, vitamina $C$, brojnih makro- i mikroelemenata (naročito $\mathrm{Fe}, \mathrm{Mg}$ i P), kao i veći sadržaj polifenola i ukupni antioksidativni kapacitet. Međutim, iako se brojni autori širom sveta već dugi niz godina bave komparacijom hutritvnog sastava organskih i konvencionalnih namirnica, jasan konsenzus da su organski proizvodi boljeg hemijskog sastava od konvencionalnih do danas nije postignut, tj. odgovori su ambivalentni. Zbog toga su neophodna dalja dugogodišnja ispitivanja, kako bi se postojeće nedoumice razjasnile.

Ključne reči: organska proizvodnja, konvencionalna proizvodnja, vitamini, minerali, sekundarni metaboliti, nitriti

Received: 17 February 2021/Received in revised form: 06 September 2021/Accepted: 08 September 2021

Available online: October 2021

This is an open-access article under the CC BY license (http://creativecommons.org/licenses/by/3.0). 